SERVIÇO DE PÓS-GRADUAÇÃO DO ICMC-USP

Data de Depósito: $\quad 31.05 .2001$

Assinatura:

\title{
SiNaCoM - Sistema de Navegação e Controle de Missão do Projeto ARARA
}

\author{
Luciana Carla Peixoto Barbosa
}

Orientador: Prof. Dr. Onofre Trindade Junior

Dissertação apresentada ao Instituto de Ciências Matemáticas e de Computação - ICMC-USP, como parte dos requisitos para obtenção do título de Mestre em Ciências de Computação e Matemática Computacional.

USP - São Carlos

Maio/2001 


\section{A Comissão Julgadora:}

Prof. Dr. Onofre Trindade Junior

Prof. Dr. Eduardo Marques

Prof. Dr. Fernando Martini Catalano

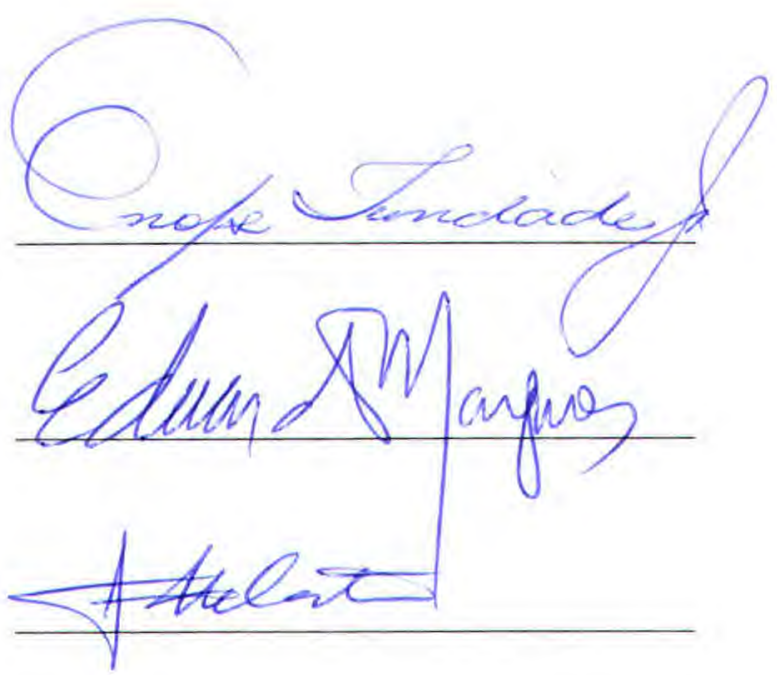




\section{Agradecimentos}

Este trabalho não seria possível sem o apoio da minha maravilhosa mãe, Dona Zizi, e do meu adorável pai, Milton. Devo tudo a eles. Também teve os dedinhos da minhas queridas irmãs, Zeca, Déia, Ná e do meu irmão Marcelo.

São muitas as pessoas que eu gostaria de agradecer de coração. Bom, vamos lá! Primeiramente, ao meu adorável orientador Onofre que tanto me ensinou sobre a vida e sobre a "navegação". Umarpessoa cheia de virtudes que não me desamparou um só minuto. Nem mesmo em seus momentos de "chatice". Foi um verdadeiro pai.

Quero agradecer muito, muito e muito a todos os amigos.

Ao Jorge, pelo apoio e pelas aulas de GA; ao Gláucio, pela ajuda (mesmo sem poder) no momento mais difícil do mestrado, no final; à Mamãe Ursa (e ao seu filhote) e à Tia Rê, que muito me ensinaram sobre "Como viver bem com duas pessoas neuróticas"; e ao Marcos que também me acompanhou nesta difícil jornada.

E à turma do "velho" LCAD. Passamos momentos que irão ficar na saudade e no coração. Tenho que agradecer muito ao Lu (Draga I), pela sua paciência ao me ensinar "coisas" de computação; ao Kebler (Draga II), pela paciência de Jô: colocar na minha cabeça como um avião faz a curva não foi tarefa fácil; ao mancebo Max, pela ... não teve muita paciência mas foi muito amigo. Ah não!! Ele está me ajudando agora a imprimir este trabalho! Obrigada, Max!!!

Tenho que agradecer também ao Fernando "Tranqüilo", que me passou um pouco de "tranqüilidade"; à querida Vi, que só chegou agora, mas chegou a tempo; ao comunista Emílio, pelas cantarolas na hora em que eu mais precisava de silêncio e ao Alex, por ficar quietinho quando eu estava brava.

Quero agradecer, em especial, ao meu noivo Rogério, por ter suportado a minha ausência. 
Aos meus queridos paise ao meu amor Rogério 


\section{Resumo}

O projeto ARARA - Autonomous and Radio-Assisted Reconnaissance Aircraft (aeronaves de reconhecimento assistidas por rádio e autônomas), está centrado no uso de aeronaves não tripuladas para a aquisição de dados. O seu objetivo principal está na substituição das aeronaves convencionais usadas na obtenção de fotografias aéreas no monitoramento de plantações e áreas sob controle ambiental.

Neste trabalho é descrito o sistema SiNaCoM, Sistema de Navegação e Controle de Missão, para o projeto ARARA, que, juntamente com um sistema de aumento de estabilidade, permitirá que aeronaves do projeto ARARA possam realizar missões de forma completamente autônoma.

O sistema SiNaCoM está dividido em dois módulos: o Planejador de Missão e o Sistema de Navegação. O primeiro módulo permite que o usuário defina uma rota e um conjunto de tarefas associado a cada waypoint da rota que será seguida pela aeronave. $O$ segundo módulo controla a navegação da aeronave, ao longo da rota traçada pelo usuário, incluindo as correções de curso necessárias ocasionadas por rajadas de vento. A navegação é baseada no sistema de posicionamento GPS e em um conjunto de sensores de navegação instalados a bordo da aeronave.

O Planejador de Missão foi implementado e produz na saída um plano de vôo para ser carregado na aeronave. O sistema de navegação foi completamente definido, projetado e o algoritmo foi especificado em sua quase totalidade. A implementação depende do hardware que será utilizado a bordo das aeronaves e foi deixada como trabalho futuro. 


\section{Abstract}

The ARARA project - Autonomous and Radio-Assisted Reconnaissance Aircraft, is centered on the use of Unmanned Aircraft for data acquisition. Its main goal is the replacement of conventional aircraft used to take aerial photographs for the monitoring of crops and areas under environmental control.

This work describes SiNaCoM, a Navigation and Mission Control System for the ARARA project. SiNaCoM jointly with a Stability Augmentation System will provide ARARA aircraft with fully-autonomous mission accomplishment capability.

SiNaCoM is split into two modules: the Mission Planner and the Navigation system. The first module allows the user to define the route of a flight and a set of tasks to be carried out at each waypoint in this route. The second module controls the navigation of the aircraft along the route defined by the user, performing course corrections due to wind gusts. Navigation is based on the GPS positioning system and a set of on-board navigational sensors.

The Mission Planner has been implemented and outputs a flight plan that can be loaded onto the aircraft. The Navigation System has been fully defined, designed and has an almost completely specified algorithm. Its implementation depends on the hardware that will be adopted on board of the aircraft and has been left as future work. 


\section{Sumário}

1 NNTRODUÇÃO

1

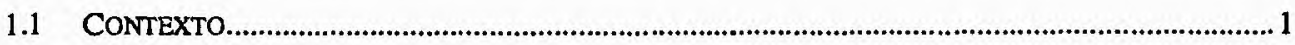

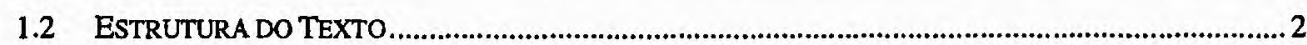

2 REVISÃO BIBLIOGRÁFICA

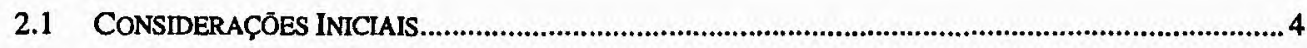

2.2 AERONAVES NAO TRIPULADAS ......................................................................................

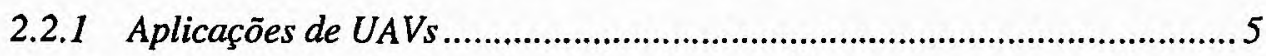

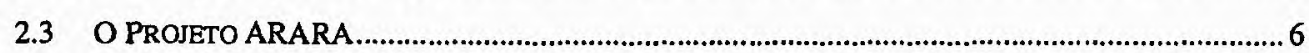

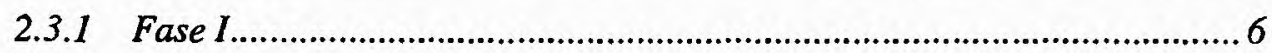

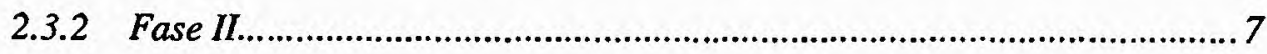

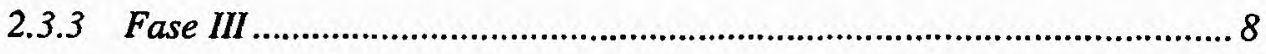

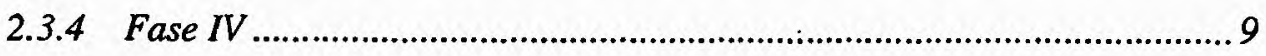

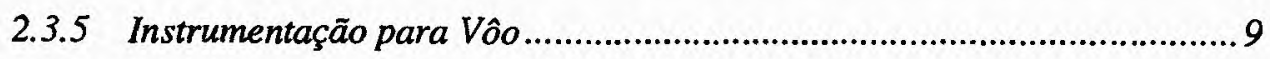

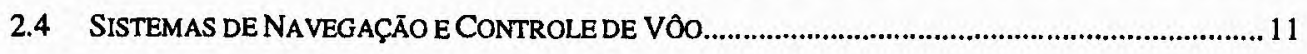

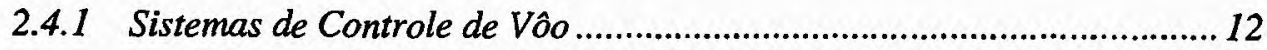

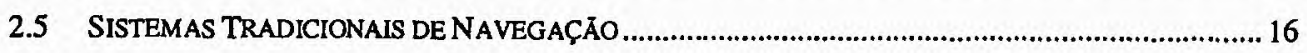

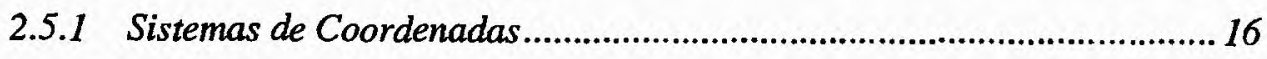

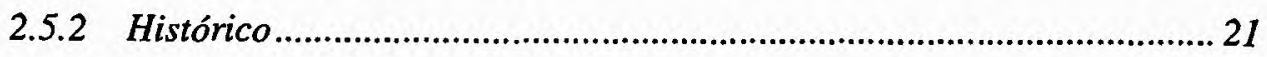

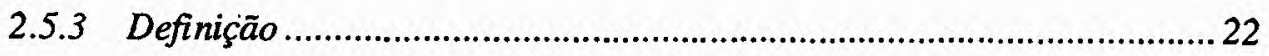

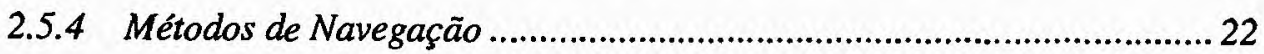

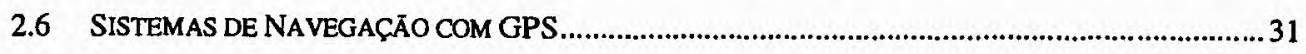

2.6.1 Funcionamento Básico..................................................................... 33

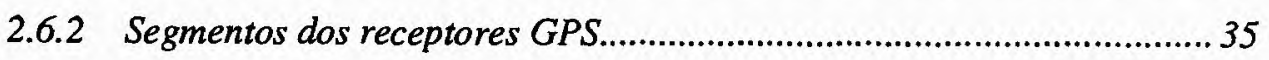

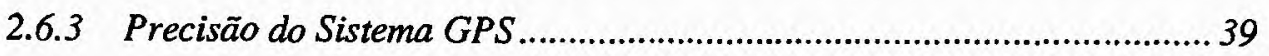

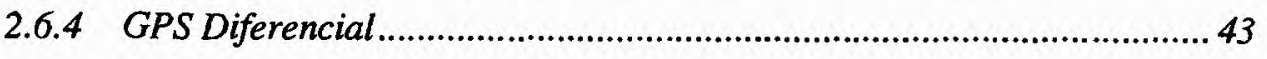

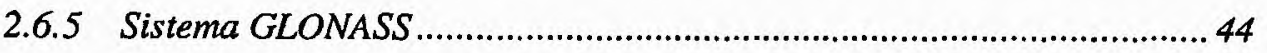

2.6.6 Vantagens de Sistemas com Bases no Espaço........................................ 45

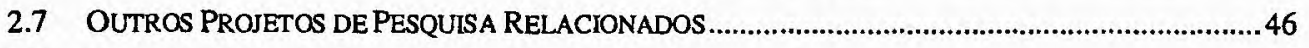


2.7.1 MAFV-Multi-purpose Autonomous Flight Vehicle ............................ 46

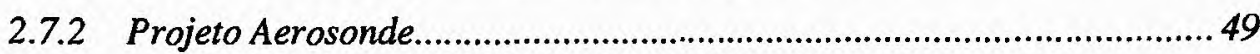

2.7.3 Projeto UAV - Uninhabited Aerial Vehicles.......................................... 50

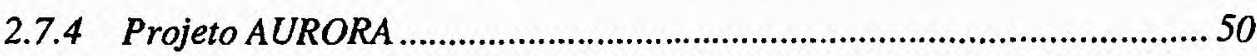

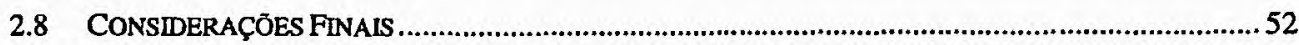

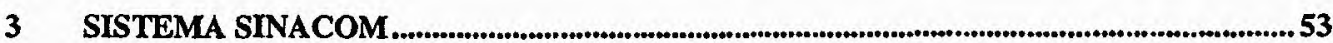

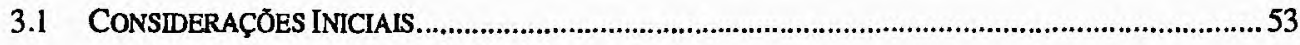

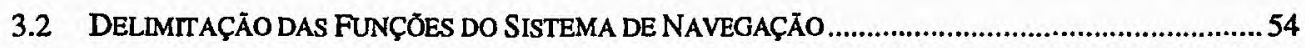

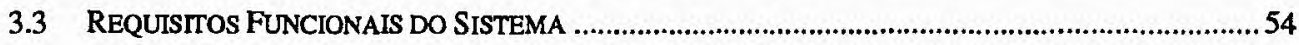

3.3.1 Requisitos Funcionais do Módulo Planejador de Missão...................... 54

3.3.2 Requisitos funcionais do módulo Sistema de Navegação ....................... 55

3.4 DIAGRAMA DE BLOCOS DA FASE III ..................................................................................5

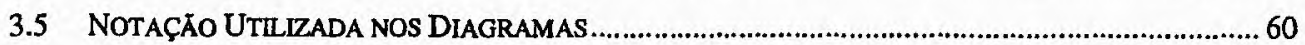

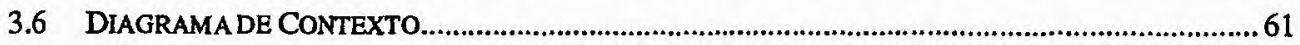

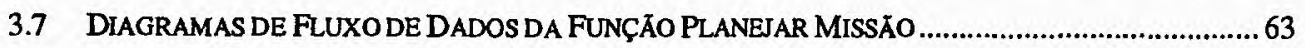

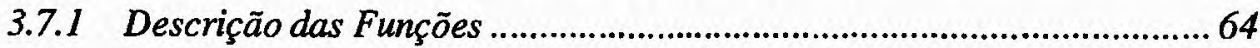

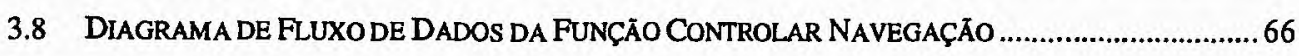

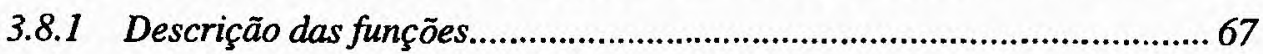

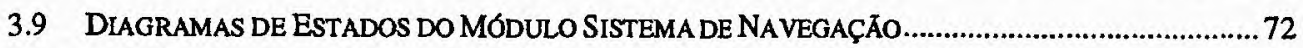

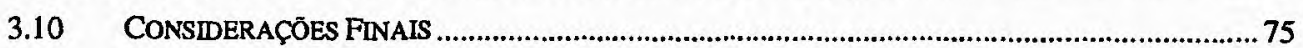

4 IMPLEMENTAÇÃO DO MÓDULO PLANEJADOR DE MISSÃO........................................76

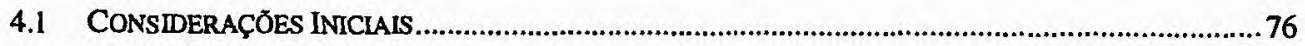

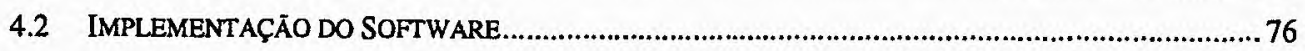

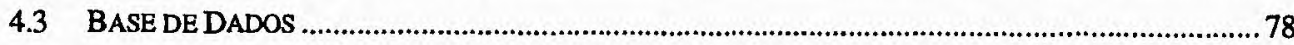

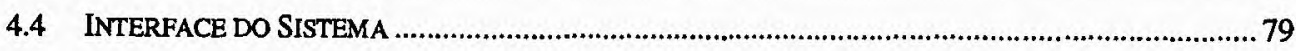

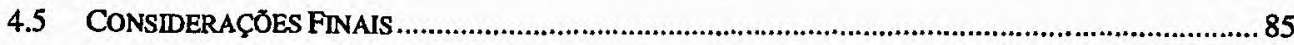

5 IMPLEMENTAÇÃO DO MÓDULO SISTEMA DE NAVEGAÇÃO ........................................86

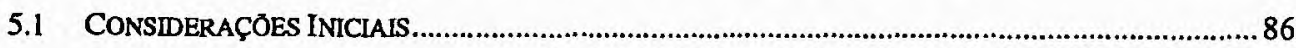

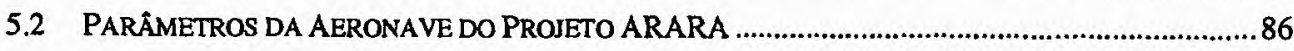

5.2.1 Parâmetros Operacionais .................................................................. 87

5.2.2 Parâmetros Não Operacionais ........................................................ 88

5.2.3 Estimativa dos Parâmetros......................................................................8 88

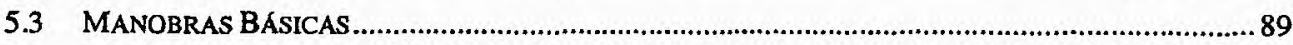

5.3.1 Classificação das Manobras Básicas.............................................. 91

5.3.2 Análise das Manobras Básicas..................................................... 91 
5.3.3 Análise das Manobras Ascendentes .........................................................93

5.3.4 Análise de Curvas Niveladas ....................................................................95

5.3.5 Síntese dos Conjuntos de Manobras para Diferentes Valores de $\theta$...... 102

5.4 ANALISE DA INFLUÊNCIA DO VENTO NA TRAJETÓRIA DA AERONAVE.......................................103

5.4.1 Airspeed, Ground Speed e Wind Speed ............................................... 103

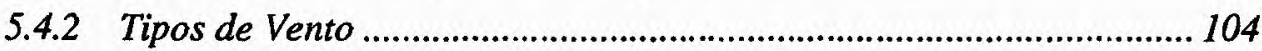

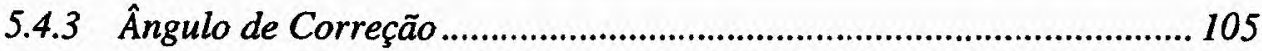

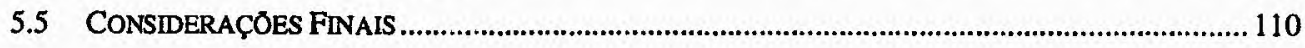

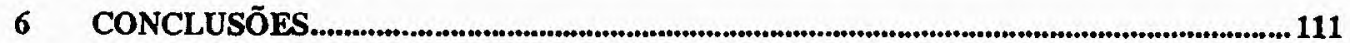

6.1 CONSIDERAÇốES INICLAIS.................................................................................................111

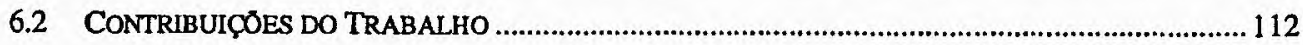

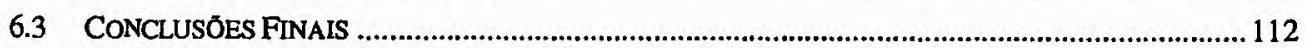

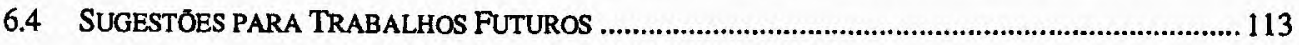

7 REFERÊNCIAS BIBLIOGRÁFICAS..............................................................................115

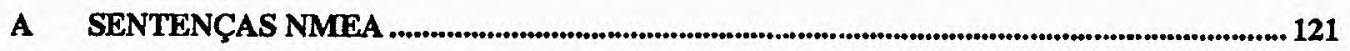

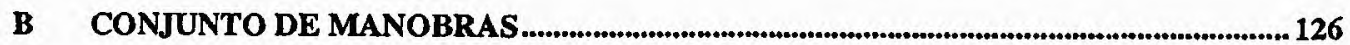

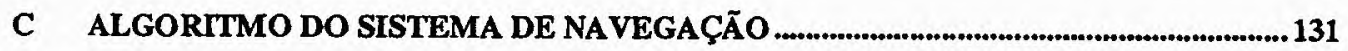




\section{Lista de Figuras}

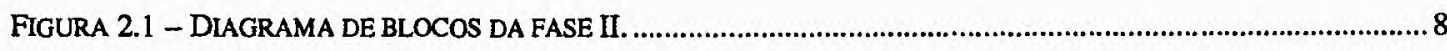

FIGURA 2.2 - RELACIONAMENTO ENTRE OS SISTEMAS DE NAVEGAÇÃO E O PILOTO AUTOMÁTICO..........................12

FIGURA 2.3 - DIAGRAMA DE BLOCOS DE UM SISTEMA DE MANUTENÇÃO DE ALTTTUDE....................................... 13

FIGURA 2.4 - DIAGRAMA DE BLOCOS DE UM SISTEMA DE MANUTENÇÃO DE VELOCIDADE. .................................. 14

FIGURA 2.5 - DIAGRAMA DE BLOCOS DA FUNÇÃO DE EXTENSÃO PARA O EIXO DE ARFAGEM. .............................. 15

FIGURA 2.6 - (A) PARALELOS DE LATITUDE E (B) MERIDIANOS DE LONGITUDE. ............................................. 17

FIGURA 2.7 - LATITUDE, LONGTTUDE E ALTITUDE DE UM PONTO P .............................................................. 18

FIGURA 2.8 - DIVISĀO DO MAPA DA TERRA EM ZONAS E BANDAS. ................................................................. 19

FIGURA 2.9 - DIVISÃO DE UMA ZONA AO MEIO PELO MERIDIANO DE ZONA.......................................................2 21

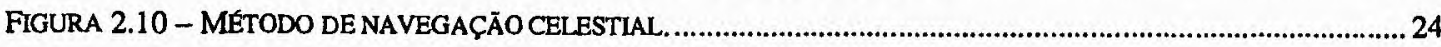

FIGURA 2.11 - DIAGRAMA DE BLOCOS DO MÉTODO DEAD RECKONING.............................................................2 27

FIGURA 2.12 - (A) SISTEMA DE RADIO-NAVEGAÇĀo ATIVA E (B) SISTEMA DE RÁdIO-NAVEGAÇÃO PASSIVA........ 29

FIGURA 2.13 - DETERMINANDO A POSIÇÃO NO SISTEMA GPS ATRAVÉS DE QUATRO SATÉLITES. ...........................34

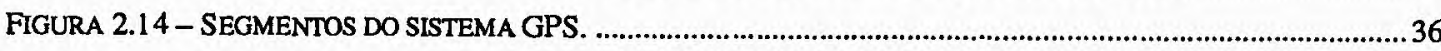

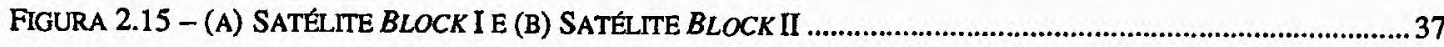

FIGURA 2.16 - DADOS COLETADOS COM SA NO DIA 1 DE MAIO DE 2000, 24 HS ANTES DO DESLIGAMENTO.......... 41

FIGURA 2.17 - DADOS COLETADOS SEM SA NO DIA 3 DE MAIO DE 2000, 24 HS DEPOIS DO DESLIGAMENTO. ........ 41

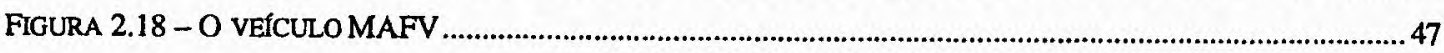

FIGURA 2.19 - ESQUEMATIZAÇĀO DO SISTEMA DE GERENCIAMENTO DE VÔO DO VEÍCULO MAFV ........................48

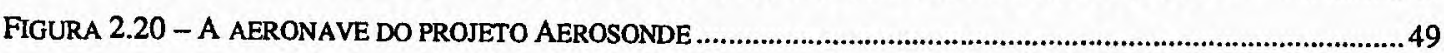

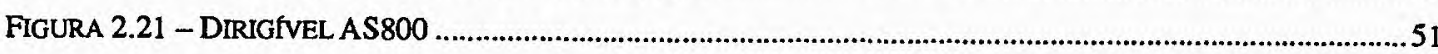

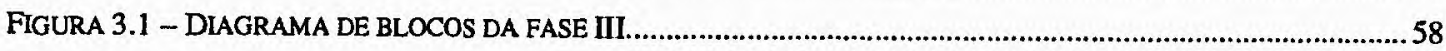

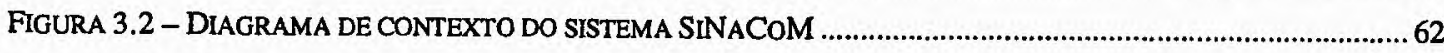

FIGURA 3.3 - DIAGRAMA DE FLUXO DE DADOS DO SISTEMA SINACOM - NIVEL 1 ...........................................63

FIGURA 3.4 - DFD DA FUNÇÃO PLANEJAR MISSÃO - NIVEL 2 .......................................................................64

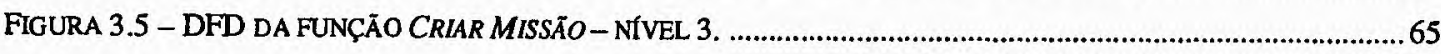

FIGURA 3.6 - DFD DA FUNÇĀO CONTROLAR NAVEGA̧̧ÃO - NIVEL 2 ..............................................................67

FIGURA 3.7 - DFD DA FUNÇÃO DECOMPOR TRECHO DE ROTA EM MANOBRAS - NIVEL 3 ....................................68

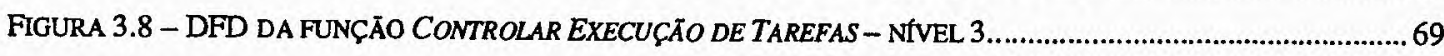

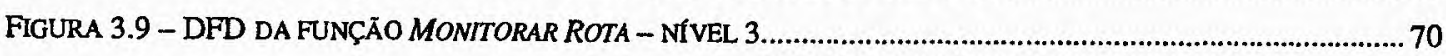

FIGURA 3.10 - DFD DA FUNÇĀO COLETAR DADOS DOS SENSORES - NIVEL 3 . .................................................. 71

FIGURA 3.11 - DFD DA FUNÇÃO CONTROLAR O ENVIO DE MANOBRAS - NIVEL 3 ................................................ 72

FIGURA 3.12 - STATECHART DO MÓDULO SISTEMA DE NAVEGAÇÃO................................................................73

FIGURA 3.13 - STATECHART DO CONTROLE DE EXECUÇĀO DE TAREFAS. ..........................................................74

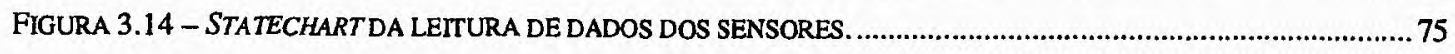


FIGURA 4.1 - OBJETOS DO COMPONENTE MOVING MAP.

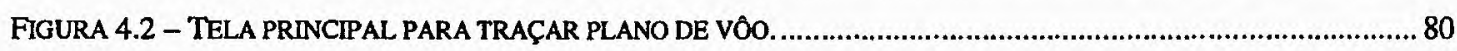

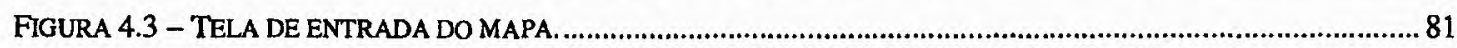

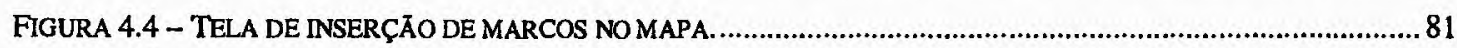

FIGURA 4.5 - TELA DE EXCLUSĀO DE MARCOS DO MAPA.

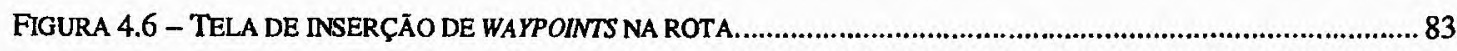

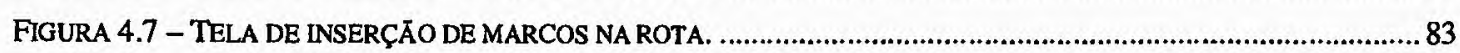

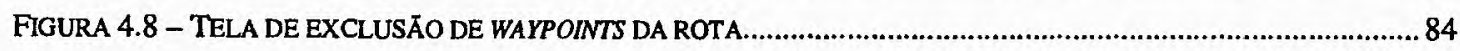

FIGURA 4.9 - TELA PARA ABRIR UMA MISSĀO PRONTA

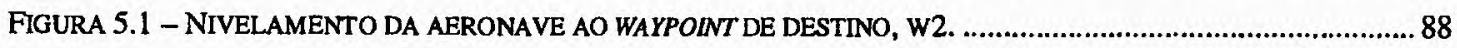

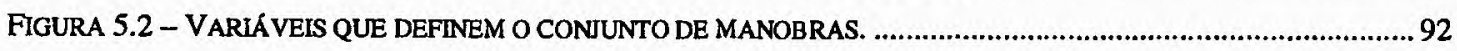

FIGURA 5.3 - POSSIVEIS DIFERENÇAS DE ALTITUDE ENTRE W1 E W2

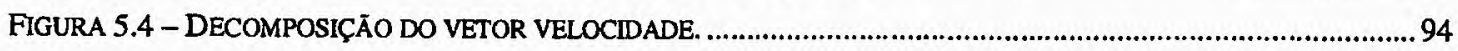

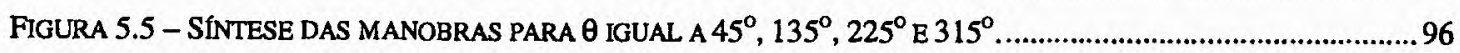

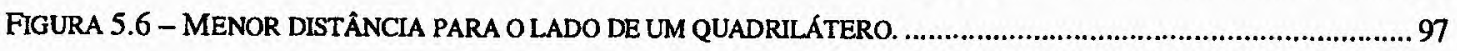

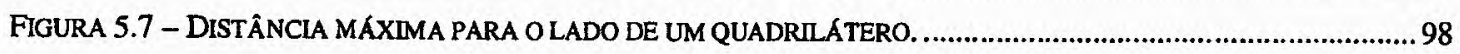

FIGURA 5.8 - STTUAÇÃO DE VÔO A SER ANALISADA PARA O CÁLCULO DE DNC...............................................99

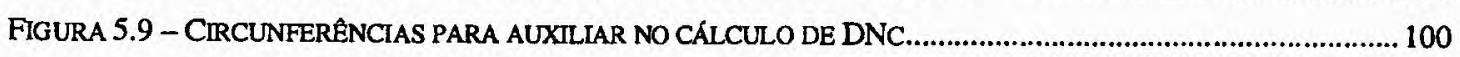

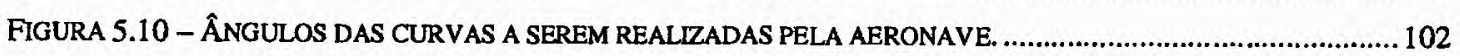

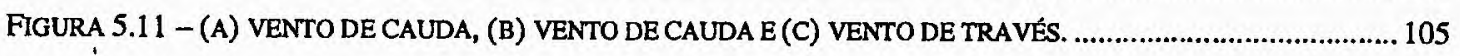

FIGURA 5.12 - INFLUÊNCIA DO VENTO NA TRAJETÓRIA DA AERONAVE. ........................................................106

FIGURA 5.13 - (A) ÂNGULO DE CORREÇÃo $\beta$ POSITIVOE (B) ÂNGULO DE CORREÇÃo $\beta$ NEGATIVO.................. 107

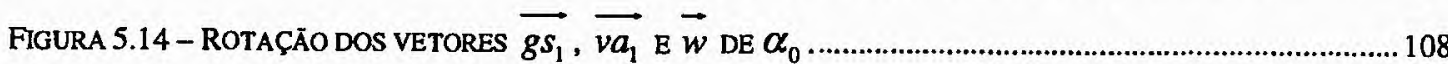




\section{Lista de Tabelas}

TABELA 2.1 - MÁXIMOS E MINIMOS PARA EASTING E NORTHING.

TABELA 2.2 - COMPARAÇÃO ENTRE OS SISTEMAS GPS E O GLONASS ……....................................................... 45

TABELA 2.3 - ETAPAS DO PROJETO AURORA

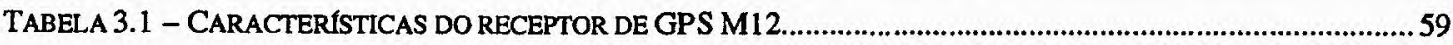

TABELA 3.2 - SENTENÇAS DO NMEA SUPORTADAS PELO RECEPTOR DE GPS M12 ….....................................59

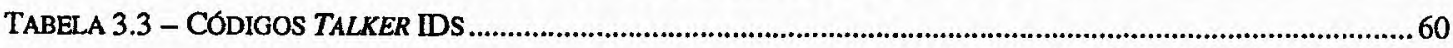

TABELA 3.4 - SÍMBOLOS UTLIZADOS NOS DIAGRAMAS DO SISTEMA SINACOM. ............................................61

TABELA B.1 - SENTENÇA GGA: DADOS DE FXAÇÃO DE POSIÇĀO................................................................. 121

TABELA B.2 - SENTENÇA GLL: DADOS DE POSIÇÃO

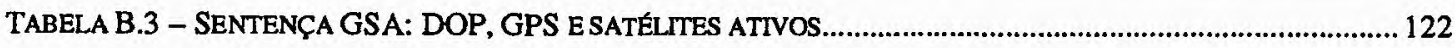

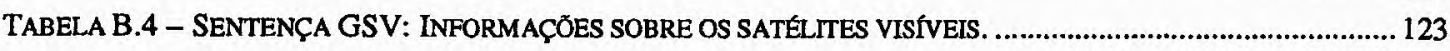

TABELA B.5 - SENTENÇA RMC: ESPECIFICAÇÃO MINIMA DE DADOS DO GPS RECOMENDADA............................... 124

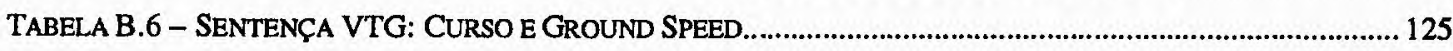

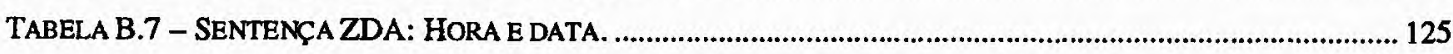

TABELAA A. 1 - CONJUNTO DE SOLUÇÕES PARA $0^{\circ} \leq \theta<90^{\circ}$ E ANÁLOGO PARA $270^{\circ}<\theta \leq 360^{\circ}$.............................127

TABELA A. 2 - CONJUNTO DE SOLUÇס̃ES PARA $90^{\circ} \leq \theta<180^{\circ}$ E ANÁLOGO PARA $180^{\circ}<\theta \leq 270^{\circ}$.......................128

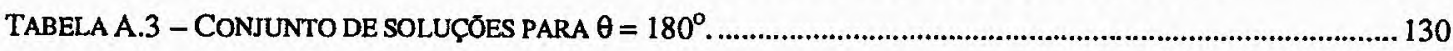




\section{Glossário}

Azimute

Aileron

Almanaque

Altímetro

Datum

Declinação Magnética

DOP

Eixo Longitudinal

Eixo Transversal

Eixo Vertical
Direção de percurso ou direção entre dois pontos em relação ao norte geográfico ou magnético. Quando expresso em graus, seu valor varia entre $0^{\circ}$ e $360^{\circ}$.

Superfície móvel localizada no bordo de fuga (extremidade traseira) da asa, a qual é comandada para realizar o movimento de rolagem da aeronave.

Espécie de arquivo de registros de cada satélite e sua órbita, embutido na memória dos receptores GPS. Utilizado para identificar e prever a localização de qualquer satélite no espaço.

Aparelho que indica o posicionamento vertical da aeronave, normalmente em pés, com base na pressão atmosférica.

Sistema de referência que descreve o tamanho e a forma da Terra.

Diferença angular entre o norte verdadeiro e o norte magnético. Varia de uma localização para outra.

Dilution of precision - informa a qualidade da geometria dos satélites. Quanto mais baixo o seu valor, melhor.

Eixo que vai do nariz até a cauda da aeronave, atravessando a fuselagem no seu comprimento.

Eixo que atravessa a aeronave da ponta de uma asa até a ponta da outra.

Eixo que atravessa a aeronave perpendicular à sua fuselagem. 
Flap

Fuselagem

HDOP

Heading

Horizonte Artificial

Inclinômetro

Landmarks

Leme

Corpo da aeronave. do vôo. guinada da aeronave. seu eixo transversal.
Superfície móvel localizada no bordo de fuga (extremidade traseira) da asa, próxima à fuselagem, a qual é comandada para baixo durante a decolagem e do pouso, com o objetivo de aumentar a curvatura ou arqueamento do perfil, aumentando, dessa forma, o coeficiente de sustentação.

Horizontal Dilution of precision - componente horizontal do DOP; ou seja, as coordenadas $\mathrm{x}$ e $\mathrm{y}$.

Também conhecido como proa, é a direção magnética na qual o nariz da aeronave está apontando. Essa não é, necessariamente, a direção do vôo (curso), mas, na prática, usa-se o mesmo termo para referir-se a ambos sentidos.

Também chamado de indicador de atitude, é um instrumento que indica qual é a posição da aeronave em relação ao horizonte. Possui 2 movimentos: lateral - mostra a inclinação da aeronave no seu eixo de rolamento ou longitudinal e - horizontal - mostra a inclinação da aeronave no seu eixo lateral ou transversal

Indica se a curva está ou não coordenada, ou seja, se o eixo longitudinal da aeronave está ou não em paralelo com a direção

Pontos de referência utilizados para orientação.

Leme de direção. Superfície móvel, localizada no bordo de fuga (extremidade traseira) da deriva ou estabilizador vertical da aeronave, a qual é comandada para se fazer o movimento de

Movimento de Arfagem Movimento de levantare abaixar o nariz da aeronave em torno do 
Movimento de Guinada Movimento de desviar o nariz da aeronave para a esquerda ou direita em torno do seu eixo vertical.

Movimento de

Rolamento

Osciladores a Cristal

PDOP

PRN

Profundor

Rate of Turn

Relógios Atômicos

SNR

Superfícies de Controle
Movimento de inclinação das asas da aeronave em torno de seu eixo longitudinal.

Uma fatia pequena de quartzo aparelhado com dimensões precisas para oscilar em uma determinada freqüência com alta precisão.

Position Dilution of precision - componente de posição do DOP, ou seja, coordenadas tridimensionais $\mathrm{x}, \mathrm{y}$ e $\mathrm{z}$.

Pseudo Random Number - cada satélite do sistema GPS possui um número PRN único.

Também chamado de leme de profundidade ou elevator. Superfície móvel localizada no bordo de fuga (extremidade traseira) da asa traseira, a qual é comandada para se fazer os movimentos de arfagem.

Através de um pequeno desenho de uma aeronave no Turn Coordinator, indica o lado em que a aeronave está fazendo a curva e a razão da mesma em graus por segundo.

Dispositivo de medição de tempo de alta precisão cuja estabilidade é baseada no comportamento quântico de partículas gasosas de elementos tais como césio, hidrogênio e rubídio.

Signal to Noise Ratio - também chamado de nível de sinal. Unidade utlizada para descrever a potência do sinal de um satélite.

Planos móveis conectados à aeronave, através de sistemas com dobradiças. A pressão do ar, de encontro a essas superfícies durante o vôo e de acordo com o grau de inclinação comandado a 
elas, determina as diversas posições (atitudes) da aeronave no espaço. Essas superfícies são os ailerons, flaps, leme, profundor e os compensadores.

Taxa de Climb

TTFF

Tubo de Pitot

Turn Coordinator

UTC

VDOP

Velocidade

Aerodinâmica
Indica a razão de subida ou descida de uma aeronave.

Time To First Fix - tempo que o receptor GPS gasta para receber informações sobre os satélites disponíveis no momento.

Dispositivo que capta as pressões dinâmica e estática do ar extemo. Dinâmica, é a pressão de impacto do ar com a aeronave em vôo. Estática é a pressão atmosférica local.

Aparelho que indica a razão da curva e sua coordenação. Na verdade, este aparelho se divide em dois: Rate of Turn e Inclinômetro.

Universal Time Coordinate - hora de Greenwich. Também pode ser interpretada como a diferença entre a hora de Greenwich e a hora local.

Vertical Dilution of precision - componente vertical do DOP, ou seja, componente $\mathrm{z}$ (altitude).

Também chamada de velocidade relativa ou airspeed, é a velocidade com que a aeronave atravessa a massa de ar.

Velocidade de Cruzeiro Velocidade média da aeronave durante o vôo nivelado e reto.

Velocímetro

Aparelho que indica a velocidade relativa do ar, em knots, também denominada velocidade indicada.

Waypoints

Coordenadas de uma posição no globo terrestre. As coordenadas são especificadas em latitude, longitude e altitude. 


\section{Capítulo 1}

\section{Introdução}

\subsection{Contexto}

O avanço tecnológico verificado nos últimos anos resultou na redução do custo e no aumento do poder computacional dos microcontroladores, na disponibilidade de sistemas de navegação de precisão e no desenvolvimento e miniaturização de sensores eletrônicos. Estes fatores facilitaram em muito o desenvolvimento de UAVs autônomos para diversas aplicações.

$\mathrm{Na}$ agricultura, a fotografia aérea tem sido utilizada como uma ferramenta suplementar na identificação de problemas, tais como perdas na produção causadas por pragas, insetos, fungos e elementos atmosféricos. A coleta de dados para monitoramento ambiental é outra área que têm feito uso de UAVs e se beneficiado da miniaturização do GPS (Global Positioning System), da câmera de vídeo, da câmera fotográfica digital, dos equipamentos de rádio e dos sensores para coleta de dados atmosféricos.

$\mathrm{Na}$ área militar, os UAVs são utilizados em missões de reconhecimento e prática de tiro ao alvo. São projetados para reutilização, diferentemente dos mísseis, utilizados uma única vez. Embora os UAVs apresentem um custo relativamente pequeno, em aplicações militares, um projeto de UAV pode chegar facilmente à casa de dezenas ou até mesmo centenas de milhares de dólares.

Enquanto a maioria dos projetos de pesquisa em UAVs tem orientação militar, outros projetos têm caráter predominantemente científico, com aplicações não militares. Neste contexto pode-se citar o projeto ARARA - Autonomous and Radio-Assisted Reconnaissance Aircraft (aeronaves de reconhecimento assistidas por rádio e autônomas). O projeto ARARA 
está em desenvolvimento no Departamento de Ciências de Computação e Estatística da Universidade de São Paulo, no campus de São Carlos, sob a supervisão do Prof. Dr. Onofre Trindade Jr. Possui como objetivo principal a utilização de aeronaves em escala reduzida em substituição às aeronaves convencionais utilizadas na obtenção de fotografias aéreas para monitoramento de plantações e de áreas sob controle ambiental.

O objetivo deste trabalho é dar continuidade ao projeto ARARA. O ARARA está dividido em 4 fases, a primeira das quais é descrita no trabalho de Souza [SOU99]. Neste trabalho discuti-se a implementação de UAVs para sensoriamento remoto na agricultura. Foi construído um UAV baseado em um aeromodelo, para obtenção de fotos aéreas, equipado com uma câmera digital e um microcontrolador que dispara a câmera através de um sinal de rádio enviado pelo piloto no solo. A segunda fase do projeto foi desenvolvida por Ribeiro em [RIB00]. Trata-se de um sistema para a realização de vôos, sem visada direta da aeronave remotamente pilotada, utilizando-se os dados da instrumentação e câmeras de vídeo de bordo, além de um computador de monitoramento no solo.

Neste trabalho é abordado o sistema SiNaCoM (Sistema de Navegação e Controle de Missão) para o projeto ARARA. Este sistema é parte integrante da fase III do projeto e, juntamente com o sistema de piloto automático, possibilitará a realização de missões com vôo completamente autônomo, planejados pelo usuário no solo e carregados na aeronave imediatamente antes da realização da missão. O sistema de piloto automático encontra-se em desenvolvimento em outro trabalho de mestrado.

\subsection{Estrutura do Texto}

Este texto encontra-se dividido em 6 capítulos. O próximo capítulo apresenta os conceitos básicos sobre UAVs, bem como uma revisão sobre os componentes e equipamentos necessários para implementação desses veículos. Também são apresentados os tipos de sistemas com UAVs e uma breve descrição envol vendo os principais sistemas de coordenadas geográficas, os sistemas de navegação tradicionais, os sistemas de navegação com GPS e as funções do piloto automático. Discutem-se as vantagens dos sistemas de navegação com GPS e é apresentada uma comparação entre o sistema americano Navstar GPS e o sistema russo GLONASS. Também é incluída uma breve descrição de outros projetos de pesquisa correlatos em andamento em outras instituições. 
No terceiro capítulo são apresentados a análise de requisitos do sistema $\mathrm{SiNaCoM}$, a especificação e o projeto do sistema, bem como a sua divisão em módulos. Os dois capítulos seguintes descrevem a implementação dos módulos principais do SiNaCoM. O capítulo 4 é relacionado ao módulo Planejador de Missão e o quinto, ao módulo Sistema de Navegação. Finalmente, no sexto capítulo, são apresentadas as conclusões finais, sugestões de trabalhos futuros e são ressaltadas as contribuições dadas por este trabalho.

Um glossário, com as palavras cujo sentido é de uso específico nas áreas envolvidas, foi desenvolvido e se encontra no corpo do trabalho. No apêndice A pode ser encontrada a descrição das sentenças NMEA de comunicação com o equipamento de GPS. No apêndice B constam as manobras realizadas pela aeronave e que foram consideradas no projeto do sistema de Controle de Navegação. Finalmente, no apêndice C é apresentado o algoritmo proposto para o sistema de Controle de Navegação. 


\section{Capítulo 2}

\section{Revisão Bibliográfica}

\subsection{Considerações Iniciais}

Este capítulo tem como objetivo apresentar os diversos aspectos relacionados aos sistemas de navegação e controle de missão de uma aeronave. A seção 2.2 introduz o conceito de aeronaves não tripuladas, as diversas nomenclaturas e os tipos de sistemas para esse modelo de aeronave. $O$ projeto ARARA e suas fases de implementação são resumidos na seção 2.3. A seção 2.4 mostra o relacionamento entre o sistema de navegação e o sistema de controle de vôo automático e possibilita a delimitação das funções desses sistemas. Ainda nesta seção são apresentadas as principais funções de um controlador de vôo e o relacionamento entre os seus componentes. A seção 2.5 trata do conceito de sistemas de navegação, apresentando os principais sistemas de coordenadas, os tipos tradicionais de sistemas de navegação, os sensores e equipamentos necessários para cada tipo de sistema e as vantagens e desvantagens de cada um. A seção 2.6 apresenta o sistema GPS Navstar. Discutem-se, ainda, nesta seção, o funcionamento básico de um sistema GPS e os segmentos que o compõem, além dos fatores que interferem na precisão do sistema GPS. Concluindo a seção, discorre-se sobre as vantagens de sistemas de navegação com bases transmissoras no espaço e sobre o sistema de satélites GLONASS. A seção 2.7 destina-se a relacionar outros projetos de pesquisa na área de aeronaves autônomas e sistemas de navegação. Finalmente, na seção 2.8 , inserem-se as considerações finais deste capítulo. 


\subsection{Aeronaves Não Tripuladas}

Existe uma variedade de termos para designar aeronaves não tripuladas: UAVs (Unmanned Aerial Vehicle), UAVs (Unoccupied Air Vehicle) ou UMAs (Unmanned Aircraft).

Aeronaves não tripuladas seguem os mesmos princípios de operação das aeronaves convencionais. Normalmente, esse tipo de aeronave é construído em tamanho pequeno, algumas vezes uma réplica em escala reduzida de uma aeronave convencional. Elas contêm todos os elementos da versão em tamanho real do sistema, incluindo motor, superfícies de controle, etc. Os três tipos mais comuns de aeronaves são: aviōes, helicópteros e balōes.

Os UAVs são aeronaves que possuem um sistema de navegação automática total ou parcial, permitindo vôos autônomos com rotas pré-programadas. Recebem atualizações periódicas através de uma estação terrestre ou aérea, para correção de sua rota [SIU91].

No caso em que a aeronave está sendo seguida por um piloto humano em terra ou em um avião, ela é caracterizada como um veículo RPV (Remotely Piloted Vehicles) [SIU91]. Um RPV pode ser considerado um aeromodelo rádio-controlado $(\mathrm{R} / \mathrm{C})$ sofisticado. Os RPRVs (Remotely Piloted Research Vehicles) são RPVs em escala reduzida para aplicação em pesquisa. Eles são utilizados pelos engenheiros para estudar o comportamento das aeronaves no pouso, na decolagem ou em testes em túnel de vento [SIU91].

\subsubsection{Aplicações de UAVs}

O conceito de aeronave não tripulada tem acompanhado quase toda a história da aviação e desempenhado um papel importante em diversas aplicações. Essas aplicações dividem-se em dois grupos: militares e civis. De acordo com o tipo da aplicação, as aeronaves não tripuladas podem variar em estrutura, tamanho e modelo. Os UAVs variam desde modelos simples, como uma aeronave utilizada para lazer, equipada com uma câmera de TV, até sistemas cuja complexidade é equivalente a de uma aeronave tripulada.

Os UAVs para aplicaçōes civis têm como base aeronaves do tipo R/C (rádiocontroladas). As aplicações de aeronaves para uso civil, por sua vez, são utilizadas para:

† Vigilância costeira marítima; 
$\rightarrow$ Policiamento de descarga de óleo em águas;

$\rightarrow$ Pesquisas aéreas geológicas;

Reconhecimento de condições climáticas;

+ Monitoramento agrícola;

$\dashv$ Estudos ecológicos;

† Avaliação da estabilidade de declives naturais, barragens, pontes e outras construções feitas pelo homem.

As aeronaves para aplicações militares realizam missões mais perigosas [SIU91]. Essas missões normalmente acontecem atrás das linhas do inimigo. Os UAVs podem voar em regiões contaminadas por armas nucleares, viajando em elevadas altitudes durante horas ou mesmo dias, ou correndo alto risco de destruição. Existem diferentes projetos de UAVs para missões militares.

\subsection{O Projeto ARARA}

Seguindo uma tendência aplicada a outros projetos semelhantes, o Projeto ARARA foi dividido em quatro fases. Os resultados de cada fase representam sistemas com níveis de complexidade e custo crescentes, adequados para diferentes aplicações. Souza [SOU99], elaborou uma classificação dos UAVs em três tipos. Tal classificação foi aplicada na definição do Projeto ARARA cujas fases são descritas nas próximas seções.

\subsubsection{Fase I}

Classificada por Souza como tipo I, a mesma incorpora o mínimo de funcionalidade e apresenta o menor custo com a máxima facilidade de implementação. Nesta fase são utilizados componentes convencionais de aeromodelismo, câmeras fotográficas convencionais ou digitais e câmeras de vídeo para a obtenção de fotografias ou imagens aéreas. Neste tipo de sistema, os vôos são feitos dentro do alcance visual e controlados por equipamentos de rádiocontrole convencionais com alcance de aproximadamente $1 \mathrm{~km}$. Esse tipo de sistema é adequado para aplicações em que o vôo da aeronave pode ser controlado de uma estação em terra, da mesma forma praticada com os aeromodelos. A fase I já foi concluída por Souza [SOU99] em seu trabalho de mestrado. 


\subsubsection{Fase II}

Classificada por Souza como tipo II, esta fase envolve o projeto e a construção de um aeromodelo R/C específico para a aplicação, com uma grande variedade de sensores para o controle do vôo, tais como GPS, giroscópiọ, bússola, velocímetro, altímetro, etc. Duas câmeras de vídeo são instaladas a bordo da aeronave, uma na frente e outra apontando para baixo, transmitindo imagens em tempo real para o computador da Estação Base. A câmera instalada na frente da aeronave permite que o piloto possa voar fora do seu alcance visual, enquanto que a câmera voltada para baixo permite que o piloto possa escolher a área de interesse, As imagens de vídeo transmitidas pela aeronave são sobrepostas por uma imagem de um painel de avião. O resultado dessa combinação é semelhante aos simuladores de vôos, tal como o Flight Simulator da Microsoft.

Os instrumentos visualizados no computador são completamente funcionais com os valores mostrados obtidos dos sensores a bordo da aeronave. Essa configuração permite vôos além do alcance visual e controle da rota e altitude do vôo. Uma vez que a área escolhida para ser observada esteja sobre o foco da câmera de vídeo voltada para baixo, o piloto poderá disparar a câmera fotográfica ou acionar um gravador de vídeo. Essa etapa já foi concluída por Ribeiro [RIB00] em seu trabalho de mestrado. A figura 2.1 ilustra um diagrama de blocos de uma aeronave da fase II. 


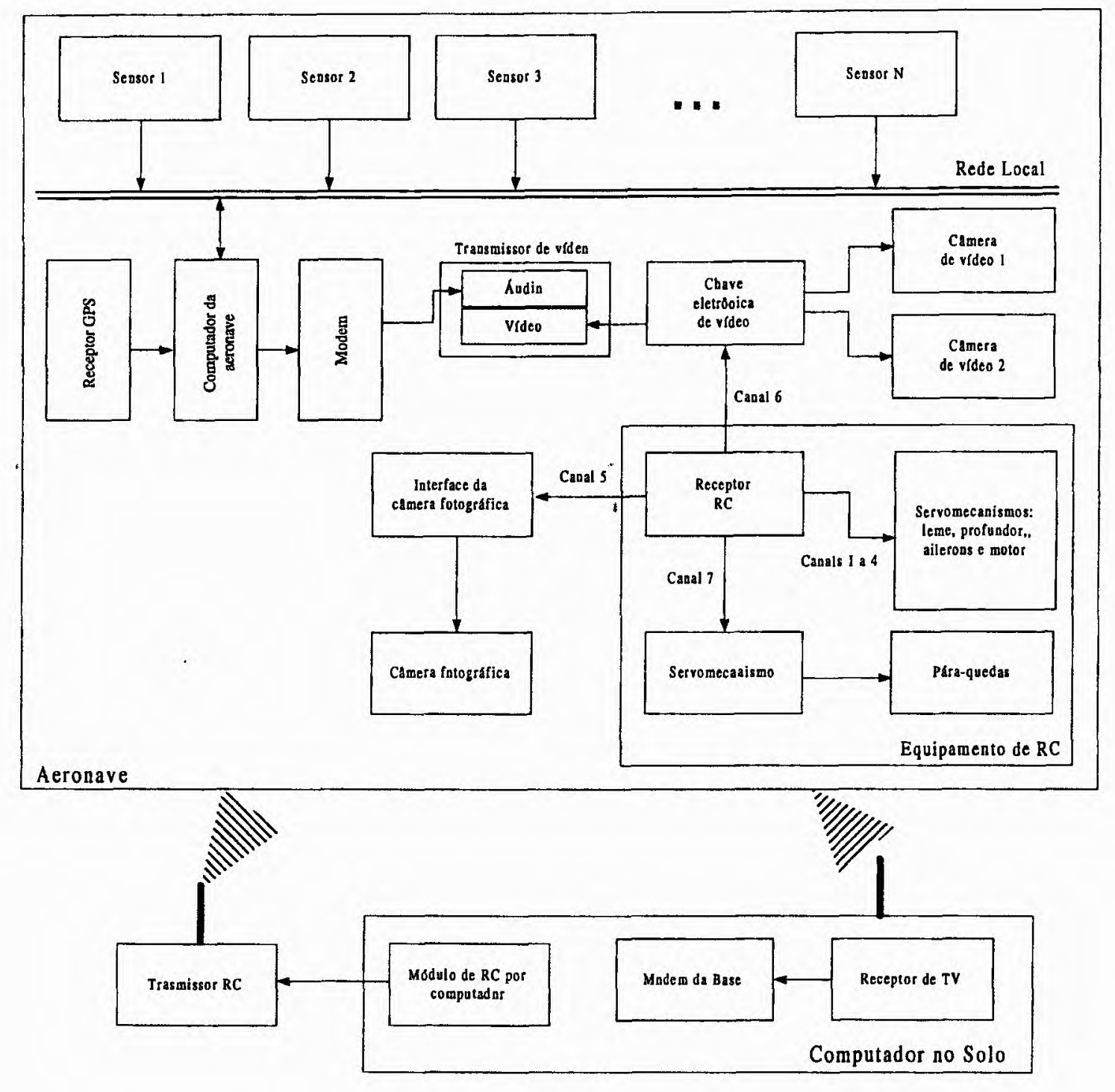

Figura 2.1 - Diagrama de blocos da fase II.

\subsubsection{Fase III}

A fase III, que se inicia com este trabalho, utiliza o mesmo tipo de aeronave da fase II. A aeronave é equipada com um sistema de navegação e um sistema de piloto automático para a realização de vôos autônomos. O usuário pode programar a rota de vôo da aeronave e as tarefas para cumprir a meta de uma missão, tais como fotografar ou filmar uma área prédefinida. 


\subsubsection{Fase IV}

Essa fase irá utilizar os sistemas desenvolvidos na fase III para a realização de missões complexas de forma totalmente automática. Nesta fase serão necessários computadores mais potentes a bordo, para a execução de missões que envolvam a tomada de decisões baseadas no processamento das imagens. A aeronave poderá identificar objetos, tais como linhas de transmissão, estradas, cursos de rios, etc, permitindo uma variedade de tarefas de monitoramento totalmente autônomas, tais como a inspeção de linhas de transmissão de energia com a finalidade de localizar possíveis falhas ou a contagem de animais em uma determinada área.

\subsubsection{Instrumentação para Vôo}

Para a realização de vôo sem visada direta (sistemas das fases II e III) são necessários diversos instrumentos de bordo. Normalmente, esses instrumentos são equivalentes aos que equipam os aviões de tamanho real e dependem das características do vôo que se deseja realizar.

Os instrumentos de vôo podem ser divididos em duas categorias: os que indicam as condições operacionais da aeronave e os que indicam as características do vôo e a posição da aeronave no espaço [PRO96].

Os seguintes instrumentos indicam a condição operacional da aeronave:

Instrumentos do motor:

- Indicador de rotação;

- Indicador da temperatura do motor;

- Indicador da pressão do óleo;

- Indicador da temperatura dos gases do escapamento;

- Indicador de combustível.

† Instrumentos que indicam as características do vôo e a posição da aeronave:

- Altímetro;

- Horizonte artificial; 
- Indicador de coordenação em curvas;

- Bússola;

- Velocímetro;

- Bússola giroscópica;

- GPS (Global Positioning System);

Muitos desses instrumentos não são necessários na aplicação prevista neste trabalho. Os instrumentos que serão utilizados na implementação do Sistema de Navegação são os sensores de velocidade, de direção e de posição. Os sensores de velocidade e de direção são discutidos a se equir e o sensor de posição, GPS, é discutido na seção 2.6.

\subsubsection{Sensores de Velocidade}

A velocidade em relação ao meio no qual o veículo está viajando é de fácil medição. $O$ sensor utilizado para se obter a velocidade de uma aeronave é o velocímetro. Trata-se de um manômetro de pressão diferencial muito sensível, que indica a velocidade da aeronave em relação à massa de ar que ela atravessa, e não a velocidade em relação ao solo. Um dispositivo utilizado para esse fim é denominado tubo de Pitot. O velocímetro mede a diferença entre a pressão dinâmica e a pressão estática sobre o Pitot. Essas duas pressões serão iguais quando a aeronave estiver em ar calmo ou parada no solo. Quando a aeronave move-se para frente, a pressão na linha do Pitot torna-se maior do que a pressão atmosférica. Essa diferença é indicada pelo ponteiro do velocímetro na face do instrumento, que está calibrado para oferecer esta indicação ao piloto, em milhas terrestres por hora (MHP) ou milhas náuticas por hora (Kt).

A velocidade em relação ao solo é dada pelo receptor GPS que será discutido na seção 2.6.

\subsubsection{Sensores de Direção}

Um dos instrumentos mais utilizados para se obter a direção de um veículo é a bússola magnética. Ela é formada, basicamente, por uma agulha imantada montada sobre uma(bóia) imersa em um líquido, que pode oscilar livremente e girar sobre os eixos vertical e horizontal. 
Desse modo, a agulha indicará sempre o norte magnético ${ }^{1}$ da Terra. Sobre a bóia está montado um mostrador dividido de $0^{\circ}$ a $360^{\circ}$. Qualquer que seja a direção seguida pela aeronave, a agulha magnética apontará para o norte magnético. Como resultado, o cartão numerado indicará um número, cujo valor em graus equivale ao ângulo formado pela trajetória da aeronave com o meridiano da Terra que passa pelo norte magnético-

A bússola magnética é afetada pelo balanço e inclinação da aeronave. É difícil orientar-se rapidamente pela mesma, principalmente em vôos mais precisos, como no vôo exclusivamente por referência a instrumentos. Uma solução para esse problema é a utilização da bússola baseada em um giroscópio, a bússola giroscópica.

O giroscópio é um dispositivo constituído por uma roda giratória cujo eixo de giro não muda de direção, a menos que uma força atue sobre a roda. Tal roda mantém-se suspensa por um conjunto de anéis concêntricos (gimbals) que permitem a ela girar livremente sem atrito em qualquer direção. Quando o eixo inercial do giroscópio é configurado para apontar para o norte geográfico, ele o fará mesmo se forças forem aplicadas para alinhá-lo em outra direção.

A bússola giroscópica é geralmente mais utilizada em sistemas de navegação devido ao fato de apontar para o norte verdadeiro (norte geográfico) e não para o norte magnético.

\subsection{Sistemas de Navegação e Controle de Vôo}

Os sistemas de navegação têm como função principal obter a posição de uma aeronave, relativa a algum sistema de referência, e calcular os comandos de direção. $O$ controle de vôo, também conhecido como piloto automático, tem como função estabilizar e manobrar a aeronave em resposta aos comandos de direção. O relacionamento entre os sistemas de navegação e o piloto automático é ilustrado na figura 2.2 [KAY69].

\footnotetext{
${ }^{1}$ Existem dois nortes: o geográfico e o magnético. O norte geográfico está localizado literalmente no pólo norte da Terra, coincidindo com o eixo de rotaçāo do Planeta e, por isso, é também chamado de norte verdadeiro; já no norte magnético é onde se encontra o magnetismo terrestre e ele nāo coincide com o eixo de rotaçāo da Terra.
} 


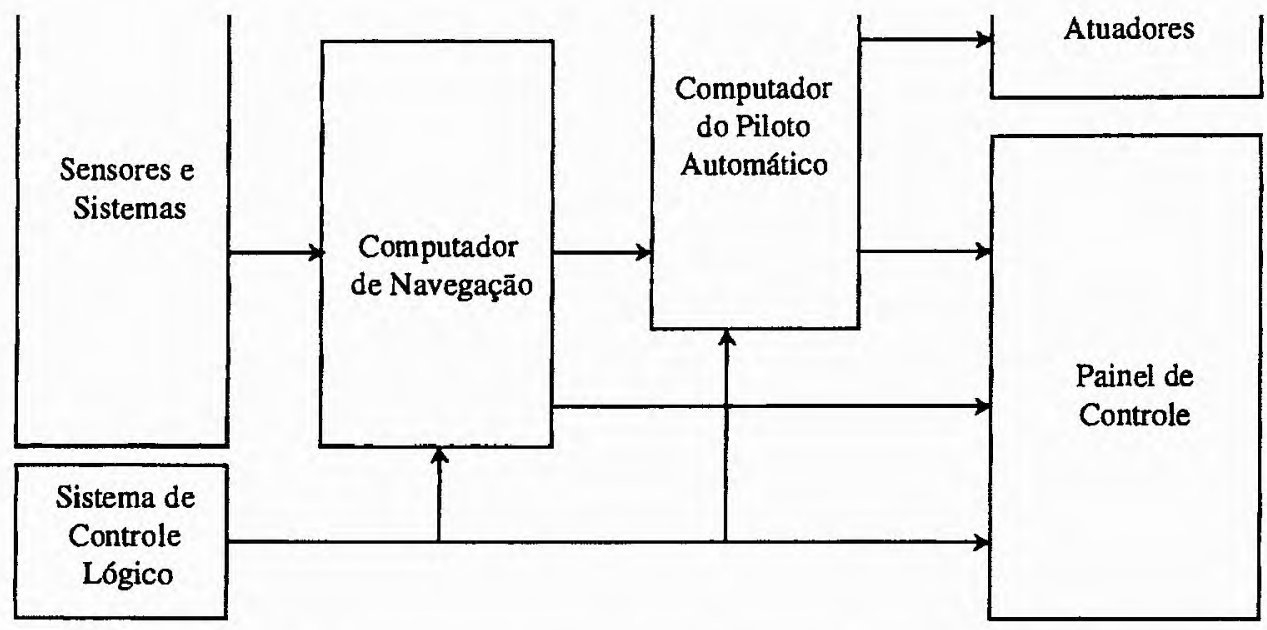

Figura 2.2 - Relacionamento entre os sistemas de navegação e o piloto automático.

Os dados de entrada do computador de navegação são sinais de diversos sensores que representam o desvio ou erro na posição, velocidade ou direção da aeronave em um dado momento. O piloto automático combina essa informação com os dados recebidos de vários sensores e sistemas para calcular os comandos das manobras. A informação resultante, exibida no painel de controle, permite que o piloto humano possa efetuar as manobras necessárias. Essa informação também pode ser utilizada pelo piloto automático, que realiza as manobras automaticamente, através da intervenção direta nos atuadores. O sistema de controle lógico permite configurar os modos de operação dos sub-sistemas descritos.

O computador de navegação realiza, basicamente, cálculos matemáticos com alto grau de precisão, velocidade moderada, poucas entradas e saídas e poucas computações paralelas. Em contrapartida, o computador do piloto automático realiza cálculos de filtragem e lógicos, utilizando um grande número de entradas, provendo muitos cálculos em paralelo e fornecendo um grande número de saídas. A precisão necessária é moderada. A velocidade da computação necessária é alta devido ao fato dos cálculos de filtragem estarem associados com a dinâmica do piloto automático.

\subsubsection{Sistemas de Controle de Vôo}

O sistema de controle de vôo automático é freqüentemente referenciado como AFCS (Automatic Flight Control System) ou piloto automático. O piloto automático também é usado em navios, foguetes e mísseis. Os equipamentos que compreendem o piloto automático 
incluem sensores, controladores, atuadores e painel de controle e, por serem equipamentos de bordo, são projetados para ter peso e volume pequenos, além de alta confiabilidade.

O piloto automático é um dispositivo que controla uma aeronave em um vôo padrão pré-programado sem a intervenção humana e tem como função principal estabilizar as características dinâmicas dessa aeronave. Ele controla a atitude, direção e velocidade da aeronave e a "pilota" ao longo de uma rota selecionada.

O desenvolvimento e a construção de um piloto automático para uma aeronave em particular requer um alto grau de coordenação entre a estrutura (airframe) da aeronave, o conjunto de equipamentos citados acima e o usuário (piloto). A razão para a integração desses componentes é que o piloto automático atua diretamente no sistema mecânico que posiciona as superfícies de controle da aeronave. Conseqüentemente, o piloto automático tem uma grande influência no projeto do sistema mecânico da aeronave.

O sistema de controle automático de vôo possui os seguintes subsistemas ou funções [NEL98, KAY69]:

Sistema de manutenção de altitude;

Sistema de manutenção de velocidade;

$\rightarrow$ Sistema de manutenção de atitude e direção;

$\rightarrow$ Sistema de aumento de estabilidade;

$\rightarrow$ Sistema de controle de rota.

\subsubsection{Sistema de Manutenção de Altitude}

A função deste sistema é minimizar o desvio entre a altitude real e a altitude desejada para a aeronave. A figura 2.3 mostra um diagrama de blocos simplificado.

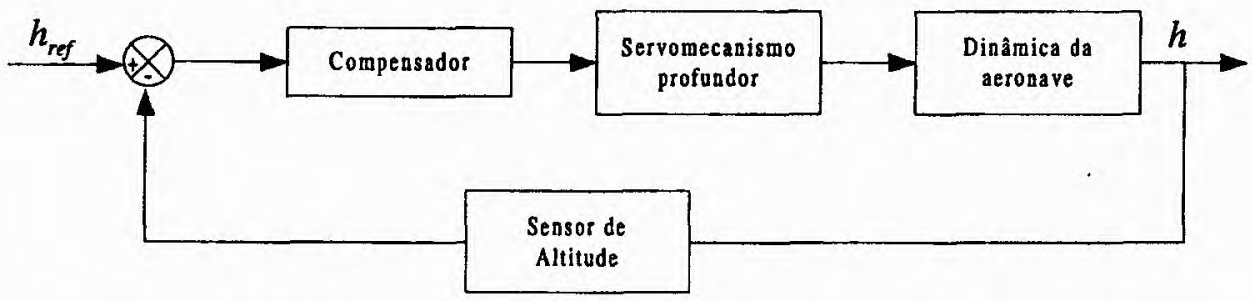

Figura 2.3 - Diagrama de blocos de um sistema de manutenção de altitude. 
Para realizar este controle, é necessário idealizar um caso onde são feitas as seguintes consideraçōes: a velocidade da aeronave é controlada por um sistema de controle separado; é desconsiderado qualquer efeito de dinâmica lateral; e, o único movimento possível para a aeronave é no plano vertical.

\subsubsection{Sistema de Manutenção de Velocidade}

A velocidade de um aviāo pode ser controlada mudando a força produzida pelo sistema de propulsão. A função do sistema de controle de velocidade é manter a velocidade de vôo desejada. Este sistema pode incluir um compensạdor, um controle do acelerador, a dinâmica do avião e uma realimentação de velocidade e aceleração. A figura 2.4 mostra um diagrama de blocos simplificado do sistema de controle para manutenção de velocidade.

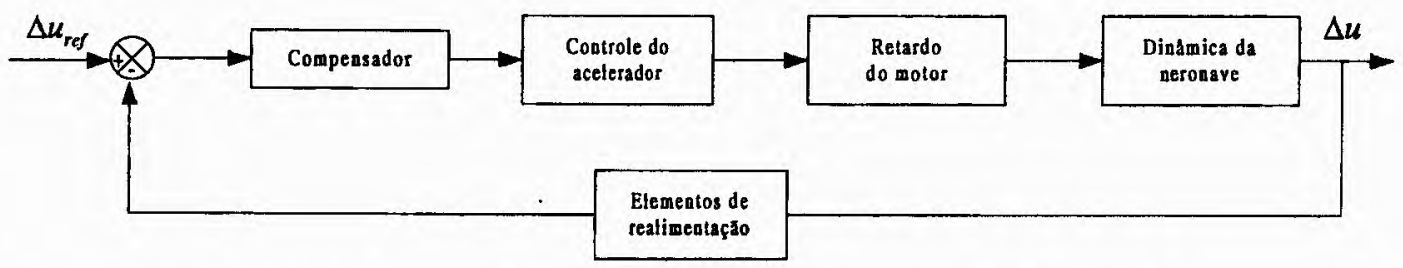

Figura 2.4 - Diagrama de blocos de um sistema de manutenção de velocidade.

\subsubsection{Sistema de Aumento de Estabilidade}

Este subsistema provê um amortecimento das respostas dinâmicas da aeronave às rajadas de vento, nos movimentos de rolamento, arfagem e guinada, além de melhora na qualidade de pilotagem manual da aeronave. Em alguns casos, fornece ainda coordenação em manobras de inclinação.

A necessidade da utilização deste subsistema depende das características da aeronave. Por vezes, a necessidade é mínima. Entretanto, existe um grande número de casos em que o aumento de estabilidade é essencial, como nos vôos que devem ser extremamente seguros.

Para amortecer as respostas dinamicas, as taxas de movimento dos ângulos da aeronave sobre seus eixos de rolamento, arfagem e guinada são obtidas através de sensores e realimentadas no computador do piloto automático. O computador combina e filtra, apropriadamente, essa informação, e calcula comandos para serem aplicados aos atuadores. Os atuadores, por sua vez, posicionam as superfícies de controle (leme, aileron e profundor) 
da aeronave para resultar em movimentos aerodinâmicos que se opõem aos movimentos angulares. O diagrama de blocos da figura 2.5 [KAY69] ilustra o aumento de estabilidade para o eixo de arfagem. Os diagramas de blocos para os eixos de rolamento e guinada são similares.

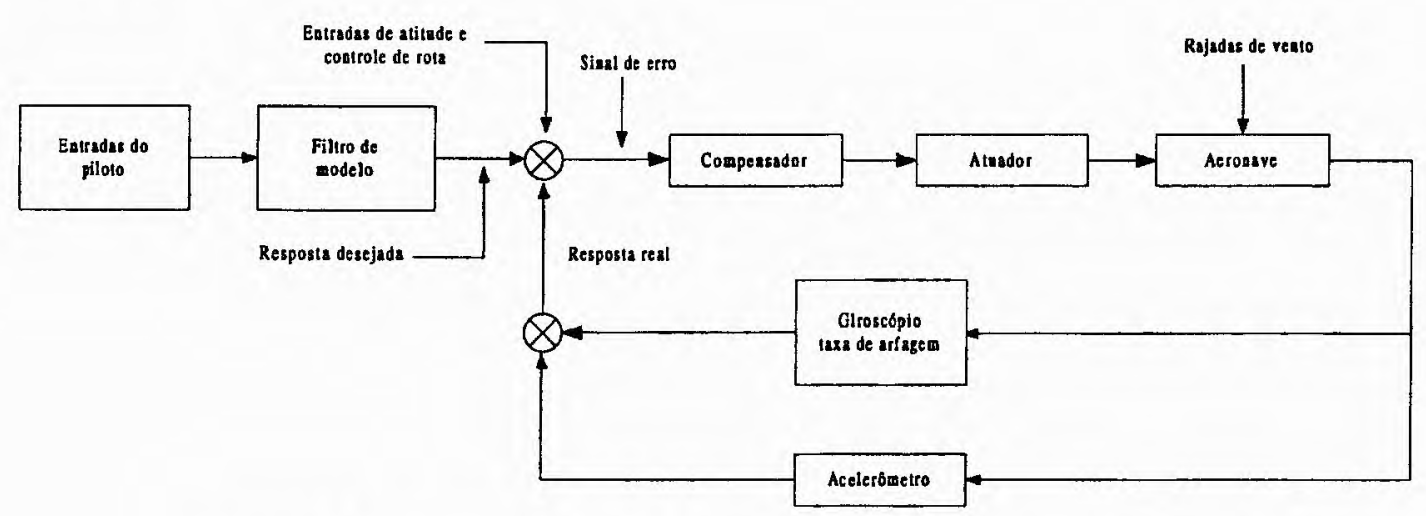

Figura 2.5 - Diagrama de blocos da função de extensão para o eixo de arfagem.

As entradas do sistema ilustrado na figura 2.5 consistem de entradas provenientes do piloto humano, da atitude da aeronave e das entradas do controle de rota. As rajadas de vento atuam sobre a aeronave. $O$ filtro de modelo e o compensador estão incluídos no computador do piloto automático.

Para fornecer uma melhor qualidade de pilotagem manual da aeronave, a força aplicada pelo piloto nos pedais do leme e no manche é medida através de sensores. Os sinais elétricos derivados dos sensores são aplicados a um filtro que modela a resposta desejada da aeronave aos sinais. Posteriormente, os sinais são introduzidos em um laço de controle interno constituído por compensador, atuadores, aeronave e sensores de movimento.

\subsubsection{Sistema de Manutenção de Atitude e Direção}

A função de manutenção de atitude e direção fornece um controle preciso da atitude e da direção selecionadas para a aeronave, que são mantidas até que sejam selecionados novos valores pelo piloto ou pelo sistema de navegação.

O sistema de atitude e direção pode ser uma plataforma inercial que fornece dados sobre a direção e sobre os movimentos de arfagem e rolamento ou pode se constituído por dois giroscópios (um vertical e um direcional) que fornecem as mesmas informações. Nesse caso, o giroscópio é normalmente considerado como parte do piloto automático. 


\subsubsection{Sistema de Controle de Rota}

O sistema de navegação fornece informações na forma de sinais para o piloto automático. Tais sinais representam o desvio ou erro na localização, na velocidade ou na direção da aeronave em relação a algum sistema de referência. $O$ propósito do sistema de controle de rota é o de manobrar a aeronave em resposta às entradas provenientes do sistema de navegação, a fim de alcançar e manter a rota desejada. Para realizăr essa tarefa, o sistema deve calcular os comandos de manobra introduzidos no piloto automático na forma de entradas de atitude e direção.

\subsection{Sistemas Tradicionais de Navegação}

\subsubsection{Sistemas de Coordenadas}

Os sistemas de coordenadas são métodos utilizados para identificar e localizar, em um mapa, pontos da Terra. Eles são mais utilizados em Sistemas de Informações Geográficas (GIS) e em Sistemas de Navegação. Existem vários tipos de sistemas de coordenadas, cada um adequado para cada tipo de Datum $^{2}$ e projeção ${ }^{3}$ específicos [BRY99]. Abaixo são listados alguns tipos de sistemas de coordenadas:

\& Latitude /Longitude;

$\rightarrow$ Universal Transverse Mercator (UTM);

$\downarrow$ Military Grid Reference System (MGRS);

+ World Geographic Reference System (GEOREF);

$\uparrow$ Universal Polar Stereographic (UPS).

Os sistemas de coordenadas mais utilizados são o sistema de coordenadas latitude/longitude (seção 2.5.1.1) e o sistema UTM (seção 2.5.1.2). Os receptores GPS utilizam o sistema de coordenadas latitude/longitude para localizar os waypoints. Existem alguns receptores que possuem a op̧̧ão de utilizar UTM como sistema de coordenadas.

${ }^{2}$ Sistemas de referências que descrevem o tamanho e a forma da Terra. Atualmente existem centenas de diferentes Datums. Dentre os modelos da Terra, o mais utilizado é o modelo Elipsoidal. Sistemas de navegação como GPS e Loran-C utilizam o modelo Elipsoidal para calcular posiçōes.

${ }^{3}$ Representaçāo da superfície da Terra em um plano. Todas as projeçōes estāo baseadas em uma das quatro classes: Projeçāo cilíndrica, cônica, azimutal e miscelânea. 


\subsubsection{Sistema de Coordenadas Latitude/Longitude}

O sistema de coordenadas latitude/longitude é atualmente o sistema mais utilizado. Trata-se de um sistema de coordenadas esféricas onde a posição fornecida é tridimensional. É um sistema baseado no Datum WGS84 onde a Terra foi definida como um elipsóide com os seguintes parâmetros de definição [PAZ00]:

$$
\begin{aligned}
& a=6.378 .137 \mathrm{~m} \\
& f=1 / 298,257223563 \\
& \text { ponto central: centro da Terra } \\
& \text { orientação: plano do Equador }
\end{aligned}
$$

onde

$$
\text { a é o eixo maior do elipsóide; }
$$

f é o achatamento do elipsóide dado por $a-b / a$ onde $b$ é o eixo menor do elipsóide.

O sistema latitude/longitude divide a Terra em linhas de latitude e em linhas de longitude. As linhas de latitude são chamadas de paralelos e percorrem o globo em paralelo ao Equador nas direções norte e sul. $O$ valor da latitude $e 0^{\circ}$ no Equador e cresce a medida que se afasta dele e se aproxima dos pólos, conforme ilustra a figura 2.6(a) [BOW01]. O maior valor da latitude é $90^{\circ}$. As linhas de latitude são indicadas em graus, minutos e segundos seguidos das letras $\mathrm{N}$ ou $\mathrm{S}$ dependendo se a localidade está a norte (North) ou a sul (South) do Equador.

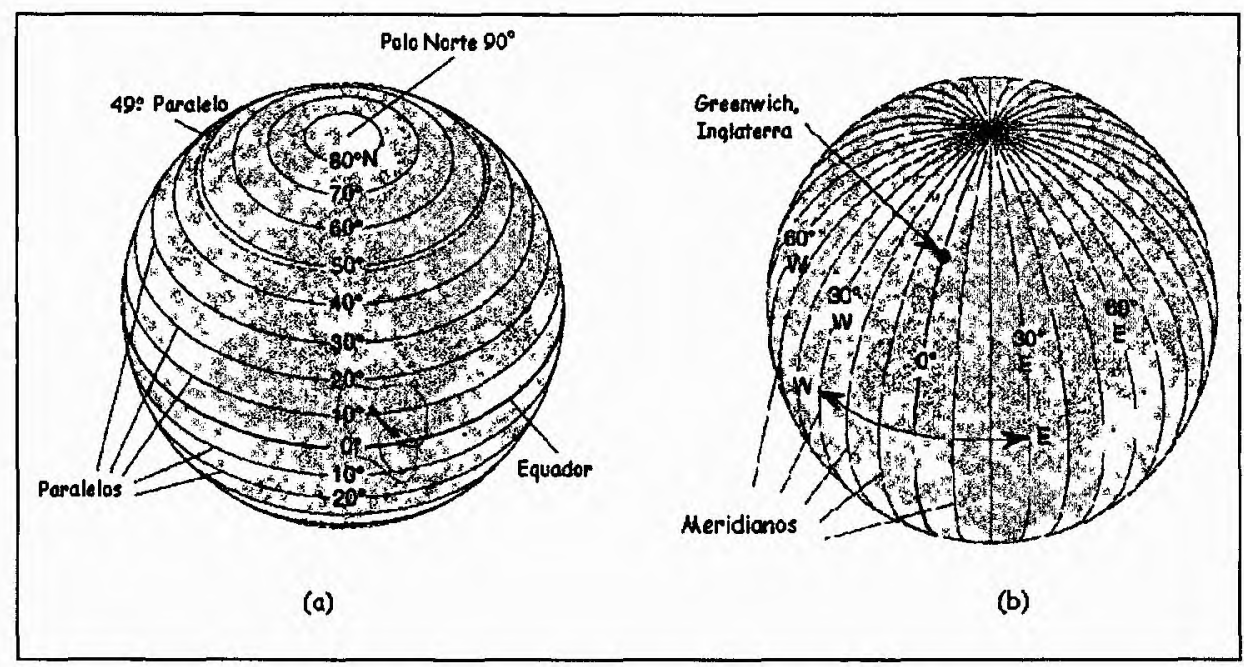

Figura 2.6 - (a) Paralelos de latitude e (b) Meridianos de Longitude. 
As linhas de longitude são perpendiculares às linhas de latitude e se cruzam nos pólos. As linhas de longitude são chamadas de meridianos e são contadas a partir do meridiano de Greenwich, meridiano que passa sobre a cidade de Greenwich, na Inglaterra, nas direções leste ou oeste. Portanto, o maior valor da longitude é $180^{\circ}$, o meridiano oposto ao de Greenwich. As linhas de longitude são indicadas em graus, minutos e segundos seguidos das letras E ou W dependendo se a localidade está a leste (East) ou a oeste (West) de Greenwich. A figura 2.6(b) ilustra os meridianos de longitude.

Os valores das coordenadas de um ponto $p$ em latitude e longitude, conforme ilustra a figura 2.7, podem ser definidos como:

Latitude $(\varphi)$ : distância angular medida em cima dos meridianos'da Terra. É medida desde o Equador até a projeção ortogonal $\left(p^{\prime}\right)$ do ponto considerado da Terra $(p)$, sobre a superfície de referência. Por convenção adota-se latitude positiva no Hemisfério Norte e negativa no Sul.

Longitude $(\lambda)$ : distância angular medida em cima do Equador desde um meridiano de origem até o meridiano de $\left(p^{\prime}\right)$. A longitude para leste do meridiano de referência geralmente é considerada positiva, sendo negativa para oeste.

Altitude $(H)$ : distância medida entre o ponto na superfície da Terra $(p)$ e sua projeção ortogonal $\left(p^{\prime}\right)$.

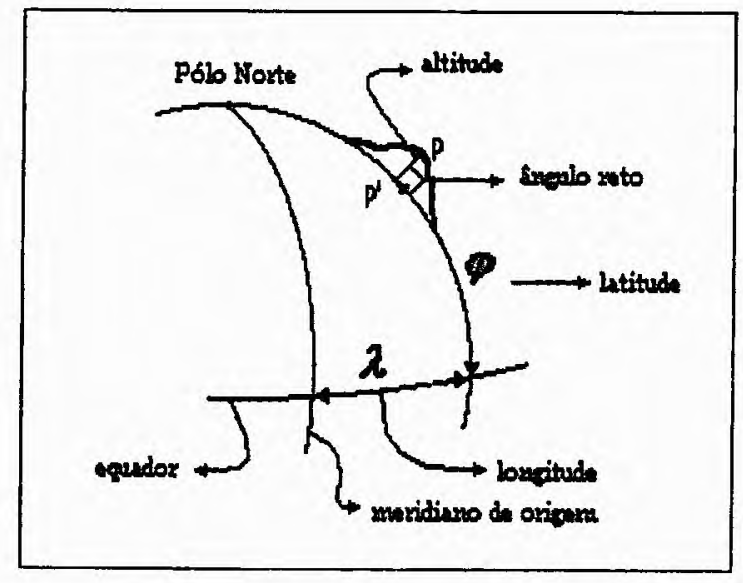

Figura 2.7 - Latitude, longitude e altitude de um ponto $p$. 


\subsubsection{Sistema de Coordenadas UTM}

O sistema de coordenadas UTM (Universal Transverse Mercator) é um sistema militar criado pelas Forças Armadas dos Estados Unidos. Trata-se de um sistema de coordenadas mais preciso que o sistema latitude/longitude.

O sistema UTM divide a Terra em 60 zonas sendo que cada uma possui $6^{\circ}$ de longitude de largura. As zonas estendem-se de $80^{\circ} \mathrm{S}$ até $84^{\circ} \mathrm{N}$ de latitude. Nas regiões polares, acima de $84^{\circ} \mathrm{N}$ e abaixo de $80^{\circ} \mathrm{S}$, é utilizado o sistema de coordenadas UPS (Universal Polar Stereographic) que foi criado especialmente para identificar pontos nos pólos.

As zonas são enumeradas de 1 até 60 , começando na longitude $180^{\circ}$ em direção ao leste. Cada zona é dividida ao meio por uma linha chamada de meridiano de zona. A zona 1 , por exemplo, estende-se de $180^{\circ} \mathrm{W}$ até $174^{\circ} \mathrm{W}$ e seu meridiano é em $177^{\circ} \mathrm{W}$. Cada zona é dividida em bandas horizontais espaçadas de $8^{\circ}$ de latitude. As bandas são rotuladas por letras começando na posição $80^{\circ} \mathrm{S}$ de latitude com a letra $\mathrm{C}$ e terminando com a letra $\mathrm{X}$ na posição $84^{\circ} \mathrm{N}$. A banda de rótulo $\mathrm{X}$ possui $12^{\circ}$ de comprimento. A figura 2.8 [DAN95] ilustra a divisão de um mapa da Terra em zonas e bandas.

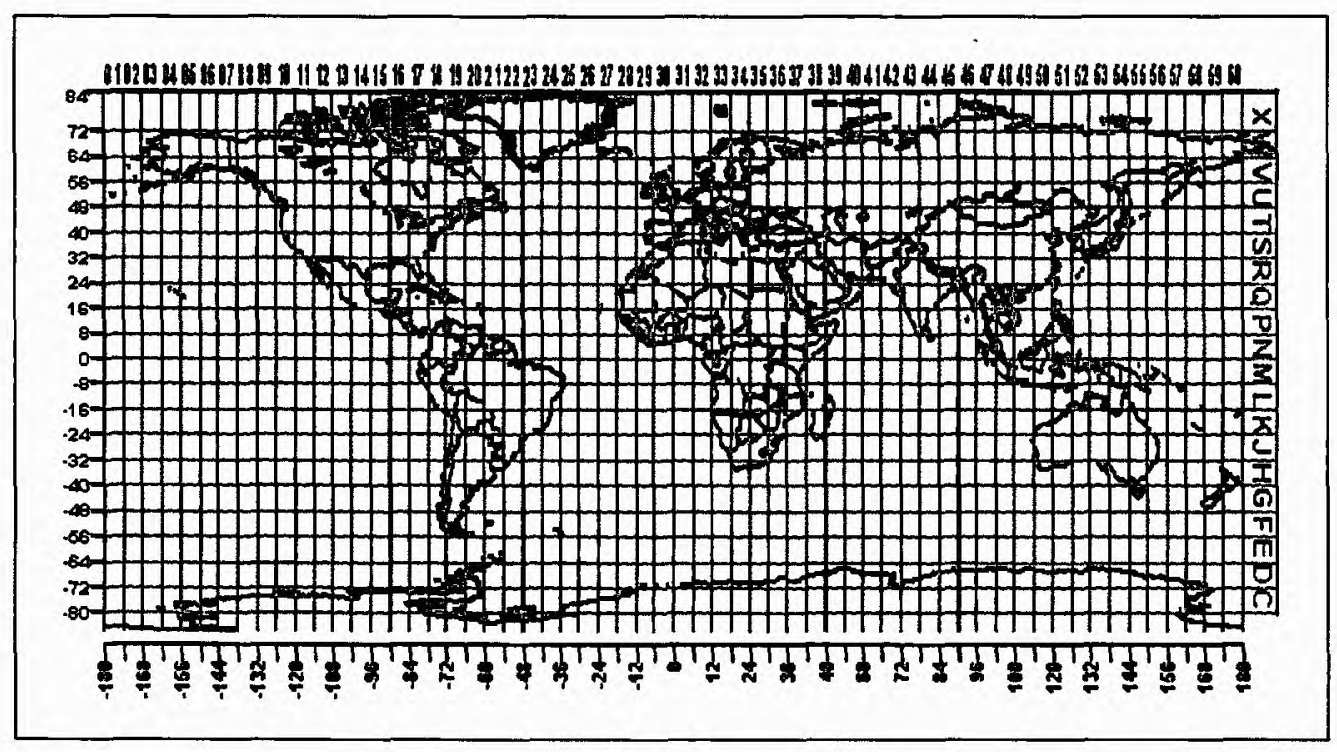

Figura 2.8 - Divisão do mapa da Terra em zonas e bandas.

As coordenadas UTM de um ponto expressam as distâncias, em metros, do ponto ao meridiano de zona e do ponto à linha do Equador. Essas distâncias são chamadas de easting e 
northing, respectivamente. Antes dos valores das coordenadas, são expressas a zona e o hemisfério da localização do ponto. A ordem dos valores de uma coordenada UTM é:

$$
\underset{\text { zona }}{11} \underbrace{N}_{\text {hemisferio }} \underbrace{360^{100 m} \cdot E_{\text {northing }}^{59} 00^{800 m} . N}_{\text {easting }}
$$

O meridiano de qualquer zona possui o valor igual a ${ }^{5} 00^{000 m}$ E. . Um ponto que possui coordenadas com valor acima de ${ }^{5} 00^{000 m} E$. significa que ele está a leste do meridiano de zona e com valor abaixo de ${ }^{5} 00^{000 m} \cdot E$. significa que o ponto está a oeste do meridiano, conforme ilustrado na figura 2.9. Um ponto que possui easting de ${ }^{5} 01^{560 m} \cdot E$. está a $1560 \mathrm{~m}$ de distância do meridiano de zona.

A distância de northing é relativa à linha do Equador que é a referência horizontal em cada zona. O valor designado para a linha do Equador é ${ }^{00} 00^{000 m} \mathrm{~N}$. para pontos ao norte e ${ }^{100} 00^{000 \mathrm{~m}} \mathrm{~N}$. para pontos ao sul, conforme ilustrado na figura 2.9. A coordenada northing de um ponto ao norte do Equador é simplesmente sua distância do Equador. Um ponto de coordenada de northing ${ }^{58} 97^{000 m} . \mathrm{N}$. está a $5.897 .000 \mathrm{~m}$ ao norte do Equador.

A coordenada northing para um ponto ao sul do Equador cujo valor é ${ }^{58} 97^{000 m .} \mathrm{N}$. é dada por $10.000 .000-5.897 .000=4.103 .000 \mathrm{~m}$, o que significa que o ponto está $4.103 .000 \mathrm{~m}$ ao sul do Equador. Desconsiderando se o ponto está ao sul ou ao norte do Equador, o valor para northing aumenta à medida que se desloca para o norte e diminui ao se deslocar para o sul. 


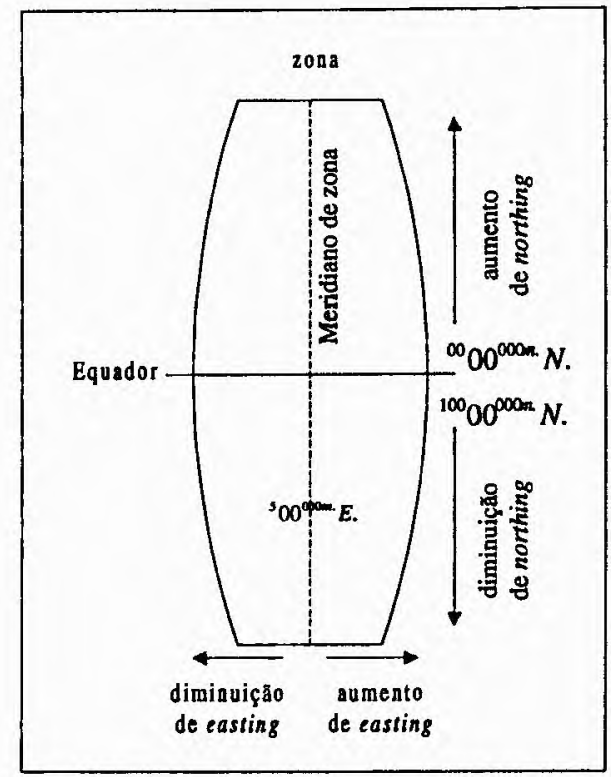

Figura 2.9 - Divisão de uma zona ao meio pelo meridiano de zona.

A tabela 2.1 mostra os valores máximos e mínimos para easting e northing em cada zona.

Tabela 2.1 - Máximos e mínimos para easting e northing.

\begin{tabular}{|c|c|c|c|}
\hline \multicolumn{2}{|c|}{ Međida } & Valor mínimo & Valor máximo \\
\hline \multicolumn{2}{|c|}{ Easting } & ${ }^{1} 66^{640 m} \cdot E$. & ${ }^{8} 33^{360 m} \cdot E$. \\
\hline \multirow{2}{*}{ Northing } & norte do Equador & ${ }^{00} 00^{000 m} \cdot N$. & ${ }^{93} 34^{060 m} \cdot N$. \\
\cline { 2 - 4 } & sul do Equador & ${ }^{11} 10^{400 m} \cdot N$. & ${ }^{100} 00^{000 m} \cdot N$. \\
\hline
\end{tabular}

\subsubsection{Histórico}

Navegação é uma arte que foi desenvolvida por marinheiros. Eles utilizavam o bom senso para determinar direção, distância, velocidade e posição de um navio, o que não é muito difícil se os pontos de referência (faróis, montanhas, torres, etc.) forem abundantes. Entretanto, quando o homem aventurou-se a navegar longe da terra, perdendo-a de vista e, portanto não podendo utilizar pontos de referência, ele se tornou capaz de utilizar elementos da natureza como o vento, as ondas e o céu para se orientar. Muitos instrumentos foram sendo desenvolvidos para aumentar a precisão e o sucesso da navegação. 
Até a invenção do aeroplano, as necessidades da marinha dirigiram o desenvolvimento da navegação. As capacidades de vôo dos primeiros aeroplanos limitavam os seus requisitos de navegação, pois eles não voavam acima das nuvens. Quando os aeroplanos se desenvolveram e o contato visual com o solo foi perdido, cresceu a necessidade de métodos de navegação sofisticados. Inicialmente, os equipamentos e técnicas de navegação da Marinha eram utilizados pelos aeroplanos, mas foram encontradas limitações severas no novo ambiente. Os sistemas de navegação e equipamentos começaram, a partir de então, a ser desenvolvidos especificamente para a aviação.

\subsubsection{Definição}

Navegação é o processo de direcionar os movimentos de um veículo de um ponto para outro [KAY69]. Esse processo envolve coordenadas de posição, direção, tempo e velocidade. $\mathrm{O}$ veículo em questão pode ser de qualquer tipo, como exemplo, um navio, um avião ou até mesmo um robó.

Formalmente, navegação é o processo de conduzir um veículo de um lugar para outro utilizando algum método de orientação. Para isso várias questões devem ser respondidas [SMI93]:

+ Qual é a posição atual?

$\downarrow$ Qual é a posição de destino?

$\rightarrow$ Como chegar ao destino a partir da posição atual?

$\rightarrow$ Qual caminho seguir?

+ Quais mudanças no percurso são necessárias?

\subsubsection{Métodos de Navegação}

Para resolver algumas destas questões, existem vários métodos de navegação. Os mais utilizados são [SMI93]:

+ Correção de Posição;

† Dead Reckoning;

+ Navegação Inercial;

† Rádio-navegação. 
Cada método envolve alguns cálculos que, no passado, eram realizados manualmente com o auxílio de mapas, réguas de cálculo, tabelas e relógios. Atualmente, os cálculos são realizados por computadores. Muitos navegadores combinam mais de dois métodos para obter uma melhor precisão.

\subsubsection{Correção de Posição}

Este método consiste na correção da posição de um veículo em relação a um ponto de referência. É o método mais simples e o mais antigo. Existem três técnicas básicas para corrigir posições:

$\rightarrow$ Leitura de mapas;

+ Navegação celestial;

† Distância e direção de pontos identificáveis.

\section{Leitura de Mapas}

O método de leitura de mapas consiste em associar o que pode ser visto a olho nu com um mapa, e pode ser utilizado apenas em condições climáticas adequadas. Em condições climáticas ruins, entretanto, pode-se utilizar um radar para fornecer a visão, uma técnica bastante utilizada em navios, a fim de se evitar colisões [SMI93].

O radar pode ser utilizado na navegação aérea para obter imagens do que existe abaixo e à frente da aeronave. A associação dessas imagens com o mapa era uma função realizada pelo homem até a automatização deste processo, que possibilitou a utilização de um banco de dados digital.

\section{Navegação Celestial}

Durante séculos, a navegação celestial tem sido o único meio de correção de posição disponível para os marinheiros em mar aberto. Para se definir uma posição sobre a superfície da Terra, utilizando os astros celestiais, é necessário calcular as seguintes variáveis sobre os astros [REI96]:

Posição Geográfica do astro (PG): ponto onde a reta que liga o astro ao centro da Terra 'fura' a sua superfície. Na figura 2.10(a), a PG está representada pela letra X. 
Distância Zenital: distância da posição do navegador $\mathrm{P}$ ao ponto $\mathrm{X}$, representado na figura $2.10(a)$.

Os astros estão a grande distância da Terra, de modo que os raios de luz que deles provêm e que incidem sobre a PG (ponto $X$ ) e sobre o navegador (ponto $P$ ) são paralelos. Deste modo, conforme ilustrado na figura 2.10(a), pode-se concluir que a distância zenital (PX), medida em graus, é igual ao ângulo que o navegador observa entre o astro e a vertical. As coordenadas do ponto $\mathrm{PG}^{4}$ podem ser encontradas em um almanaque náutico.

É mais fácil medir o ângulo formado entre a horizontal e o astro. Este ângulo, para a navegação celestial, é denominado altura (H) do astro. A altura do astro é obtida por um sextante que mede o ângulo entre o horizonte e o astro. Pela figura $2.10(a)$, pode-se ver que a distância zénital é igual a $90^{\circ}$ menos a altura do astro.

A distância zenital e a PG do astro fornece então um círculo cujo centro é a PG e o raio é a distância zenital. A localização do navegador está em algum ponto sobre este círculo. Realizando os mesmos cálculos para mais dois astros diferentes, a interseç̧ão dos três círculos encontrados fornece a posição do navegador, conforme ilustra a figura $2.10(b)$.

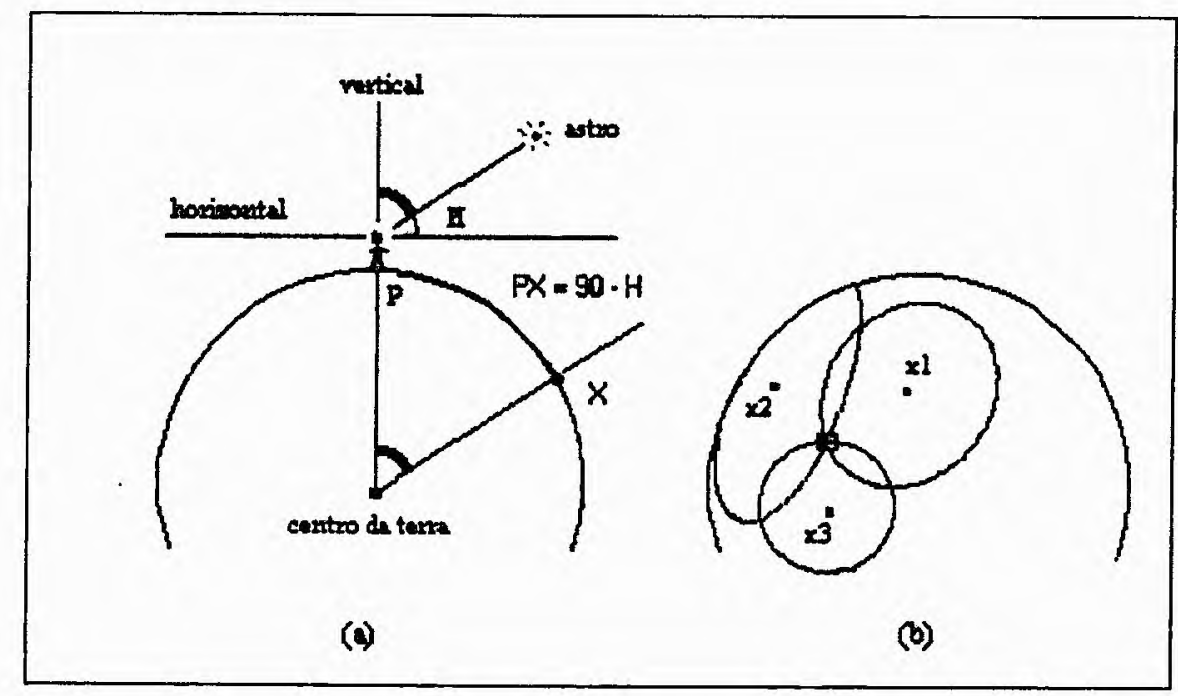

Figura 2.10 - Método de navegaçāo celestial.

\footnotetext{
${ }^{4}$ As coordenadas de uma PG, inclinação e AHG (Ângulo Horário em Greenwich) são análogas às coordenadas latitude e longitude, respectivamente.
} 


\section{Distância e Direção de Pontos Identificáveis}

Este método é o mais utilizado na Marinha e é a base da maioria dos sistemas modernos de correção de posição. Trata-se de uma técnica que utiliza as direções e distâncias do veículo até pontos (torres, faróis, estações de rádio, etc.) cujas posições são conhecidas, para obter a posição do veículo através de cálculos trigonométricos. A posição do veículo é encontrada por meio da interseção das linhas das direções ou dos círculos de alcance e distância quando essas linhas são transcritas para mapas e gráficos [SMT93].

Muitas estações de rádio, utilizadas para obter a direção de um veículo, enviam ondas em baixas e médias freqüências para obter uma grande cobertura. Ondas nessas freqüências são afetadas pelas condições atmosféricas e pela camada ionosférica, degradando a precisão de posicionamento do veículo. Para se obter uma melhor precisão, poderiam ser utilizadas ondas em altas frequiências, embora com o risco de sofrerem reflexões, o que restringe seu alcance.

Alguns sistemas foram desenvolvidos para resolver esses problemas. Os sistemas desenvolvidos utilizam transmissões dedicadas que enviam feixes de ondas de rádio, especialmente moduladas. Dentre esses sistemas, o mais utilizado é o sistema VOR (VHF Omnidirectional Range). O VOR emprega dois tipos de sinais diferentes trabalhando juntos: um feixe estreito de ondas provenientes de um farol rotacional e um pulso piscante unidirecional. O feixe de ondas gira a uma taxa constante de 30 voltas por segundo. Quando o feixe aponta na direção do Pólo Norte, o sinal piscante é irradiado brevemente em todas as direções. Um veículo irá perceber um tempo de atraso entre as recepções do pulso e do sinal proveniente do farol [LOG92].

Para se obter a distância entre um veículo e um ponto conhecido, o sistema utilizado é o DME (Distance Measurement Equipament). O DME utiliza um sistema de rádio-navegação ativa. $O$ veículo transmite um sinal que é imediatamente retransmitido em uma outra freqüência pela estação DME. A distância da estação DME é obtida multiplicando-se a metade do tempo total de viagem do sinal (ida e volta) pela velocidade da luz.

As estaçōes transmissoras do sistema VOR e DME podem estar próximas para fornecer a direção e a distância de um veículo. Um sistema similar à união do VOR com o DME é o Tacan, de uso militar, que trabalha em altas freqüências. 


\subsubsection{Dead Reckoning}

O método de navegação dead reckoning é uma técnica para calcular a posição da aeronave a partir de sua velocidade em relação ao solo (Ground Speed) e de sua direção (heading) [KAY69]. A velocidade de solo (gs) é decomposta para se obter as componentes de direção norte e leste e cada componente é multiplicada pelo tempo transcorrido desde a última posição obtida. As componentes de $g s, g s_{\text {norte }}$ e $g s_{\text {leste }}$, são dadas pelas equações:

$$
\begin{aligned}
& g s_{\text {nore }}=g s \cos \alpha \\
& g s_{\text {lesse }}=g s \operatorname{sen} \alpha
\end{aligned}
$$

onde $\alpha$ é o heading verdadeiro ${ }^{5} \mathrm{da}$ aeronave.

As distâncias norte e leste percorridas durante um certo intervalo de tempo são dadas por:

$$
\begin{aligned}
& y-y_{0}=\int_{0}^{t} g s_{\text {norre }} d t \\
& x-x_{0}=\int_{0}^{t} g s_{\text {lesse }} d t
\end{aligned}
$$

onde $g s_{\text {norte }}$ e $g s_{\text {leste }}$ são dadas pelas equações 2.1 .

As componentes de gs podem ser convertidas em medidas angulares, isto é, latitude e longitude, e adicionados à posição inicial para se obter a posição atual. A figura 2.11 ilustra o processo de dead reckoning.

\footnotetext{
${ }^{5}$ Heading medido a partir do norte verdadeiro.
} 


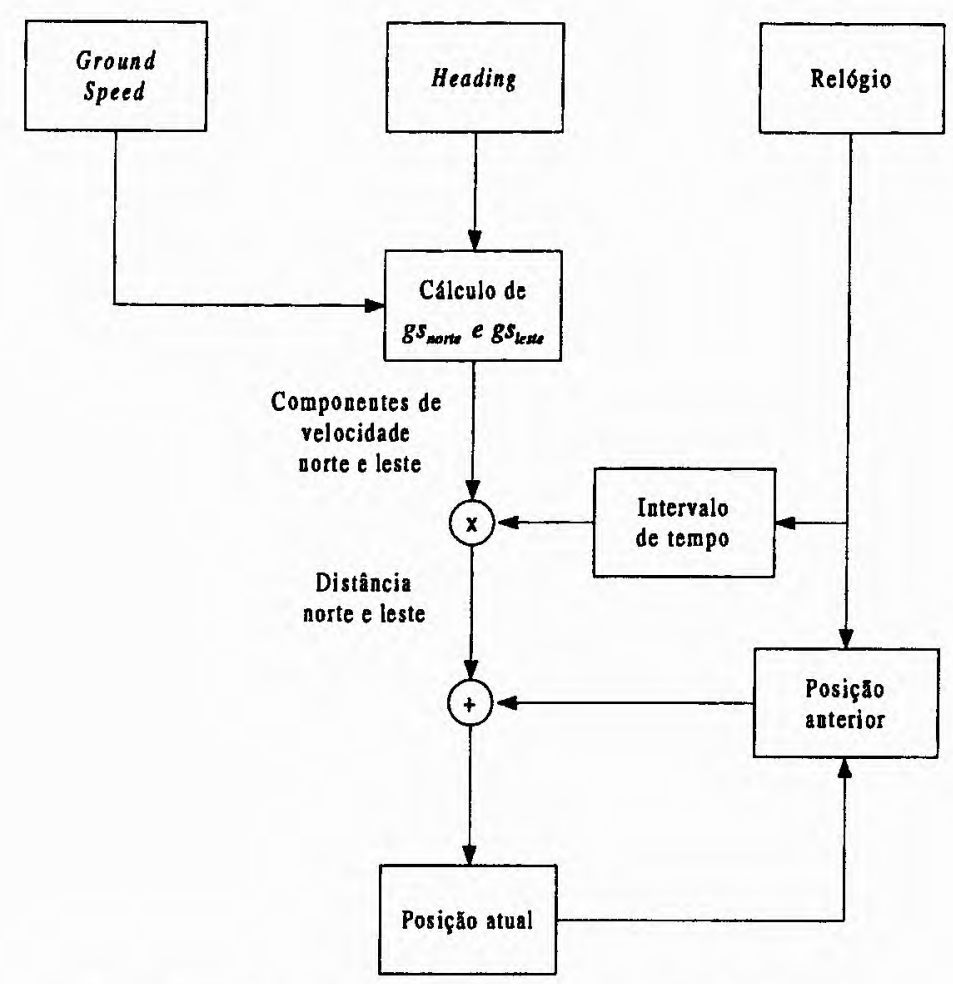

Figura 2.11 - Diagrama de blocos do método dead reckoning.

A desvantagem do método dead reckoning é o acúmulo contínuo de erro na posição do veículo com o decorrer do tempo. Para resolver esse problema, os navegadores costumam utilizar o método de correção de posição para atualizar a posição do veículo.

\subsubsection{Navegação Inercial}

O sistema de navegação inercial (INS - Inertial Navigation System) é um sistema simples e auto contido que determina a posição e a velocidade de um veículo a partir de sua aceleração [KAY69]. A aceleração é obtida através de sensores internos. A velocidade é calculada através de um processo matemático de integração e a posição atual do veículo é calculada por um segundo estágio de integração se sua posição inicial e sua velocidade forem conhecidas.

Trata-se de um sistema baseado no método dead reckoning e por isso ele possui a desvantagem de acumular, constantemente, erros na posição do veículo. Entretanto, pode-se utilizar outro método de navegação, externo ao sistema de navegação inercial, como referência para resolver esse problema, como o sistema GPS (seção 2.6) e o sistema de rádionavegação Loran C (seção 2.5.4.4). 
Comparado com os outros métodos de navegação, o sistema de navegação inercial apresenta as seguintes vantagens [KAY69]:

† Os cálculos de velocidade e posição do veículo são instantâneos e contínuos;

† Não depende de nenhum equipamento externo, ou seja, o cálculo da posição do veículo depende somente dos sensores internos ao mesmo;

+ As informações de navegação podem ser obtidas em qualquer latitude, incluindo as regiões polares, e sobre quaisquer condições climáticas, sem a necessidade de estações transmissoras no solo;

+ As informações de navegação são independentes das manobras do veículo, ao contrário do sistema Loran (seção 2.5.4.4);

† Fornece a posição, a velocidade em relação ao solo e o azimute. É o sistema mais preciso em relação ao azimute para veículos em movimento.

Os equipamentos necessários para a navegação inercial são o acelerômetro, o giroscópio e plataformas estáveis.

O acelerômetro mede a aceleração do veículo que o contém. Esse dispositivo utiliza as leis de Newton (a aceleração de um corpo é proporcional à força aplicada ao mesmo). Se uma pequena massa é suportada dentro de uma caixa de tal maneira que todas as forças na massa podem ser medidas, as medições irão representar a aceleração do corpo.

Um problema em medir a aceleração é que as forças inerciais devidas a essa aceleração não podem ser distinguidas das forças gravitacionais que atuam na massa. $O$ acelerômetro deve ser mantido horizontalmente e os sinais de gravidade devem ser compensados, a fim de se obter a medida da aceleração verdadeira.

\subsubsection{Rádio-navegação}

Rádio-navegação é um método de navegação que determina a posição de um veículo, pela medição do tempo que uma onda eletromagnética de um transmissor no solo gasta para chegar até um receptor contido no veículo em questão. Atualmente existem, pelo menos, 100 tipos diferentes de sistemas domésticos de rádio-navegação sendo utilizados. Todos eles emitem ondas eletromagnéticas, mas as técnicas que são empregadas para fixar a posição do veículo são diferentes [LOG92]. 
Os sistemas de rádio-navegação podem ser classificados, de acordo com sua complexidade, em:

Sistemas que utilizam Rádio-navegação ativa: nestes sistemas o veículo tem sua posição determinada através da transmissão de uma série de pulsos, precisamente sincronizados, para a estação, que lhe retransmite imediatamente os mesmos pulsos em uma freqüência diferente. A distância do veículo até a estação é obtida multiplicando-se a metade do tempo de viagem dos pulsos (ida e volta) pela velocidade da luz. A rádio-navegação ativa é ilustrada na figura 2.12(a).

Sistemas que utilizam Rádio-navegação passiva: nestes sistemas o veículo espera a estação emitir pulsos sincronizados e, ao receber esses pulsos, faz um cálculo do tempo de viagem dos pulsos, multiplicando esse tempo pela velocidade da luz para obter a distância da estação, conforme ilustra a figura 2.12(b).

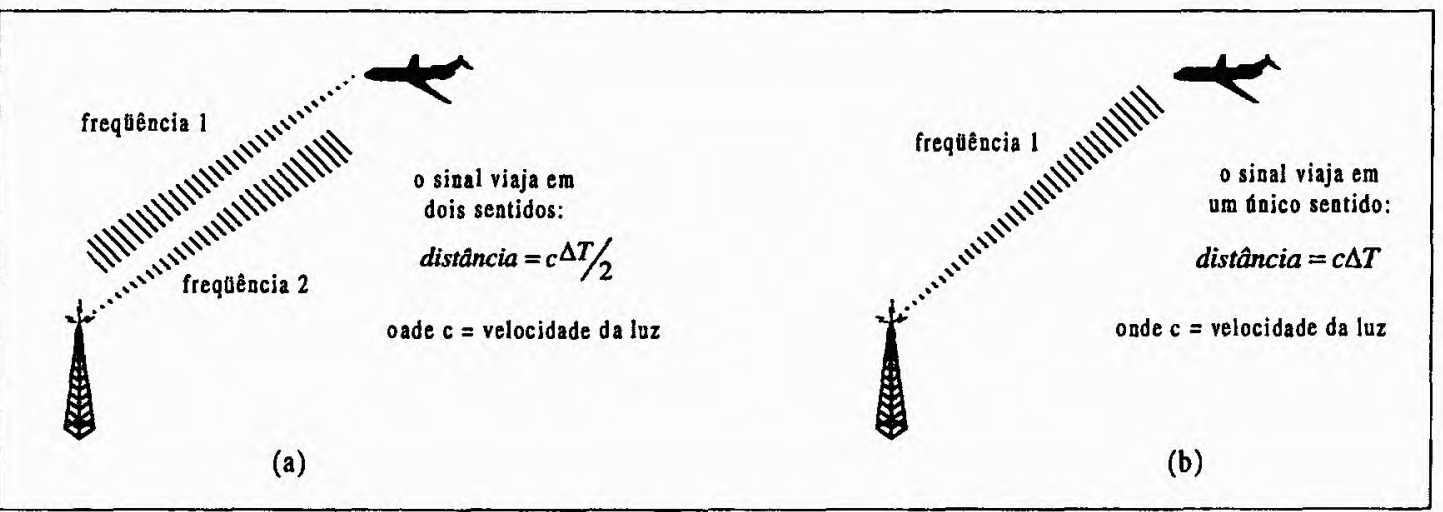

Figura 2.12 - (a) Sistema de rádio-navegação ativa e (b) Sistema de rádio-navegação passiva.

Os sistemas de rádio-navegação com bases no solo são sistemas que utilizam estações transmissoras dispersas pela Terra para determinar a posição de um veículo. Dentre esses sistemas, os mais importantes são o Omega, o Loran C/D e o Decca.

\section{O Sistema Omega}

O sistema Omega possui oito transmissores que estão distribuídos na superfície da Terra. Os transmissores Omega são phase-locked-looped, ou seja, as ondas portadoras eletromagnéticas originárias de vários transmissores estão sempre em fase. A coerência de fase é efetuada em cada transmissor pelo monitoramento das ondas portadoras dos 
transmissores vizinhos. Relógios atômicos ajudam a manter a precisão e a integridade da sincronização das fases [LOG92].

Um receptor a bordo de um veículo que captura ondas de dois dos oito transmissores Omega irá observar uma diferença de fase de chegada das ondas, o que se deve aos diferentes caminhos que as ondas percorreram até esse receptor. Se as duas ondas pudessem ser mostradas em um osciloscópio, a diferença de fase entre elas poderia ser lida. Cada fase discreta é associada a um caminho específico que fixa o veículo em uma linha hiperbólica de posição. Captando mais ondas de dois outros transmissores, o receptor fixa a posição do veículo em uma segunda linha hiperbólica de posição. A posição do usuário é então conhecida através da interseção das duas hiperb́́licas [SMI93].

Os transmissores operam em quatro VLF (very low frequency): 10.20, 11.05, $11.33 \mathrm{e}$ $13.60 \mathrm{KHz}$. Operando em freqüências baixas, o sistema Omega fornece uma cobertura global com apenas oito transmissores. Na média, as transmissões cobrem $88 \%$ da Terra durante o dia e $98 \%$ à noite. Os sinais VLF podem ser captados a qualquer profundidade debaixo da água, o que toma esse sistema adequado para submarinos.

Os oito transmissores Omega estão localizados na Noruega, Libéria, Havaí, Dakota, Diego Garcia, Argentina, Austrália e Japão. Eles operam seqüencialmente, com cada um transmitindo em uma das quatro freqüências por aproximadamente um segundo. Cada transmissão é seguida por um intervalo de silêncio de 0.2 segundos. Os oito intervalos de transmissão são espaçados no tempo; logo, não existe sobreposição entre as quatro freqüências diferentes.

\section{O Sistema Loran C/D}

O sistema Loran (LOng RAnge Navigation) foi o primeiro sistema de rádio-navegação e é o mais importante. Duas versões são atualmente utilizadas: Loran C, para fins civis, e Loran D, para fins militares.

O sistema Loran emprega a técnica de diferença no tempo de chegada das ondas portadoras. Os transmissores terrestres trabalham em pares para posicionar o veículo ao longo de uma linha hiperbólica de posição na superfície da Terra. Os transmissores do par que são referenciados como transmissor primário e transmissor secundário ficam, geralmente, separados por algumas centenas de quilômetros. $\mathrm{O}$ transmissor secundário monitora os sinais 
modulados enviados pelo transmissor primário, para manter uma sincronização em relação ao tempo [INA95].

Um receptor Loran mede a diferença de tempo de chegada dos dois sinais para determinar sua localização em uma linha hiperbólica de posição. Efetuando o mesmo procedimento para mais um par de sinais, o receptor pode determinar sua longitude e latitude na superfície da Terra [ALL96].

O sistema Loran opera na faixa de $100 \mathrm{KHz}$ com o comprimento de onda de $2.560 \mathrm{~m}$, o que torna o sistema pouco preciso (embora mais preciso que o sistema Omega). Suas ondas cobrem uma área de $2880 \mathrm{~m}$ na navegação aérea. A área de alcance chega a $4.000 \mathrm{~m}$, mas os sinais provenientes dos transmissores podem refletir na camada ionosférica e provocar um erro de posição de até $3.657,6 \mathrm{~m}$ [LOG92].

O Loran cobre a maior parte do hemisfério Norte. Atualmente mais de 50 transmissores estão em operação, mas eles fornecem uma cobertura de somente $10 \%$ da Terra.

\section{O Sistema Decca}

O sistema Decca possui os mesmos princípios básicos de funcionamento do Omega e do Loran, utilizando ondas contínuas e medição de fase para determinar a posição na linha hiperbólica de posição. Também opera na faixa de $100 \mathrm{Khz}$, o que dá ao sistema um alcance de $2.400 \mathrm{~m}$ [LOG92].

O sistema Decca utiliza um transmissor-mestre e três transmissores-escravos que transmitem sinais em frequiências sincronizadas em fase. Quando um receptor Decca captura os sinais enviados pelo transmissor-mestre, ele compara com as fases dos sinais transmitidos por transmissores-escravos para obter a posição do veículo. O resultado da posição do veículo é dado em coordenadas hiperbólicas, o que requer mapas especiais para sua interpretação, tornando difícil a utilização do sistema Decca em navegação aérea.

\subsection{Sistemas de Navegação com GPS}

A idéia de se utilizar corpos celestes para navegação acompanha o homem desde os primórdios da humanidade. Ao que tudo indica, durante muito tempo, o homem continuará 
utilizando corpos celestes para se orientar. Nos dias atuais, entretanto, sua orientação é feita com base em corpos dispostos convenientemente no espaço e sob seu inteiro controle.

A navegação astronômica possui sérios inconvenientes, dentre os quais a dependência da observação de astros que precisam estar à disposição do usuário em qualquer ponto e a qualquer hora. Ela também é imprópria para obtenção, em tempo real, da posição de usuários que se movimentam rapidamente. Em compensação, uma vantagem desse sistema é que ele pode ser utilizado por qualquer pessoa habilitada.

Outros sistemas de navegação modernos que utilizam ondas de rádio também possuem limitações: as ondas de rádio de alta frequiência proporcionam navegação precisa, 'mas são influenciadas pelo relevo. As ondas de baixa freqüência apresentam baixa precisão. Além de tudo, os equipamentos utilizados não são de fácil acesso para um usuário qualquer. Nas décadas de 60 e 70, entretanto, o uso de satélites artificiais introduziu novos sistemas de navegação que resolveram alguns desses problemas. Mas não todos.

O primeiro sistema americano de navegação por satélites foi o Transit Navigation Satellites [LOG92]. Este sistema não obteve sucesso devido à baixa altitude de seus satélites $(928 \mathrm{Km})$ o que o tornava indisponível em alguns pontos da Terra, em certos momentos. Fornecia a posição do veículo somente em duas dimensões, longitude e latitude.

O caminho para uma solução ampla foi dado através de pesquisas realizadas nas décadas de 70 e 80 pela Força Aérea dos Estados Unidos, que culminaram no desenvolvimento de um sistema de navegação por satélites denominado GPS Navstar (Global Positioning System Navstar), também conhecido apenas como GPS.

O sistema GPS foi originalmente criado para fins militares estratégicos. A partir de meados da década de 70, o seu uso foi estendido para aplicações civis, tendo passado por uma contínua evolução desde então, principalmente no que diz respeito aos equipamentos eletrônicos e programas computacionais utilizados. Atualmente, o sistema GPS é monitorado e administrado pelo Departamento de Defesa dos Estados Unidos.

O sistema GPS Navstar permite a qualquer usuário equipado com um receptor GPS determinar sua posição na superfície da Terra, a qualquer hora do dia e em qualquer lugar. Tal sistema está disponível para qualquer usuário civil ou militar. 


\subsubsection{Funcionamento Básico}

Um receptor GPS na terra, na água ou no ar captura os sinais provenientes de quatro ou mais satélites Navstar (seqüencialmente ou simultaneamente) para determinar sua posição tridimensional.

O cálculo da posição tridimensional de um veículo, realizado pelo receptor GPS, baseia-se em geometria esférica (diz que a interseç̧ão entre quatro esferas fornece um único ponto). No sistema GPS, cada satélite representa o ponto central de uma esfera cujo raio corresponde à distância entre o satélite e o receptor GPS. Para resolver este problema de geometria esférica, os microprocessadores de um receptor GPS medem a distância que os separa dos satélites, estabelecendo assim os raios de que necessitam. Para calcular a distância de cada satélite, $\epsilon$ utilizada a seguinte equação Velocidadè que a velocidade do sinal é conhecida ${ }^{6}$, é necessário então determinar o tempó gasto pelo sinal enviado, do satélite até o receptor [DOT97].

Para determinar este tempo, os satélites e os receptores são programados para gerarem um sinal codificado exatamente ao mesmo tempo. $O$ receptor estima o tempo de viagem do sinal, subtraindo a hora que o seu relogio registra o momento da recep̧̧ão do sinal do tempo indicado pelo satélite quando ele transmitiu o sinal em questão. A figura 2.13 [LOG92] mostra um receptor GPS recebendo sinais provenientes de quatro satélites.

\footnotetext{
${ }^{6}$ Os sinais de rádio viajam na velocidade da luz, ou seja, aproximadamente $300.000 \mathrm{~km} / \mathrm{s}$.
} 


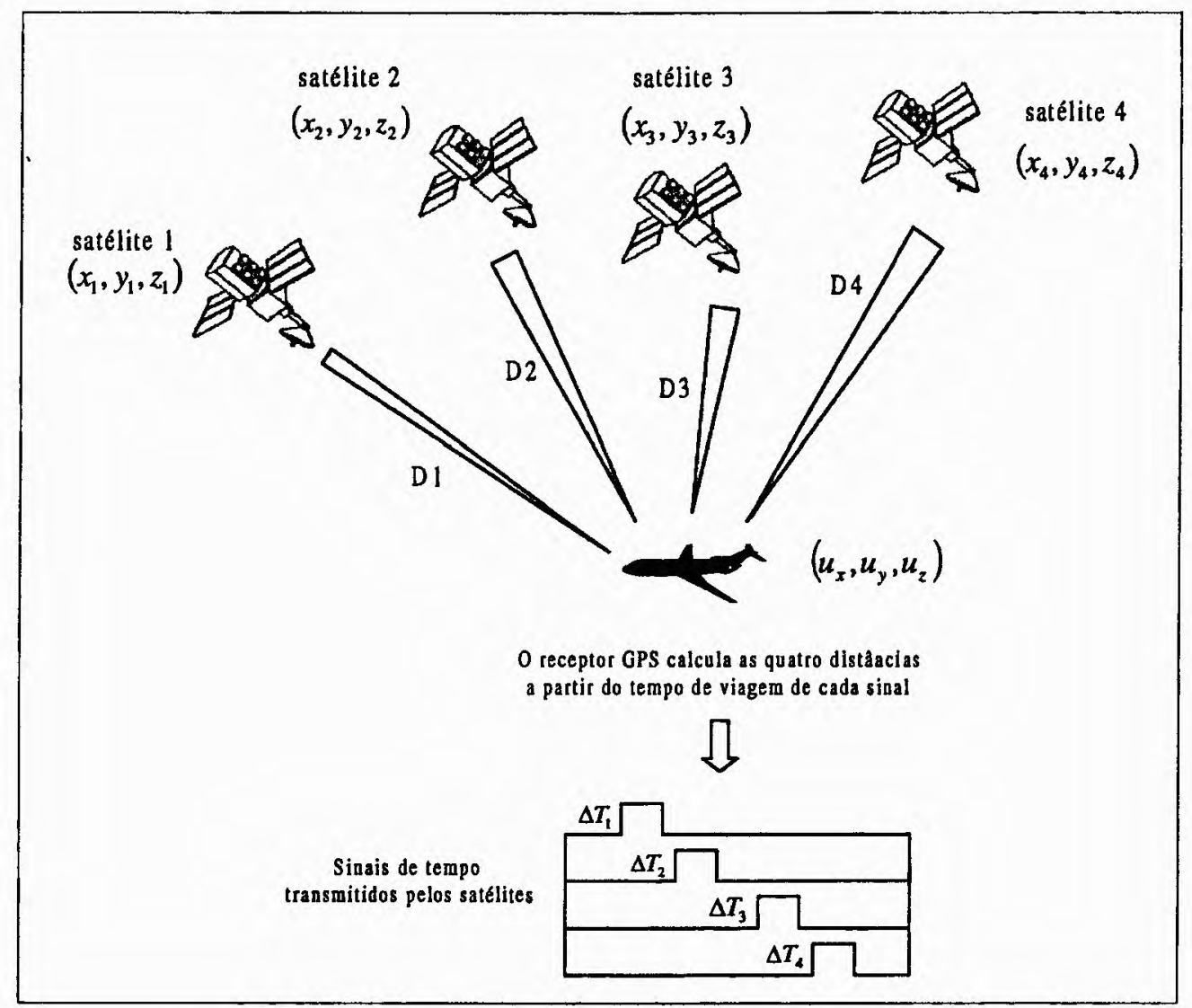

Figura 2.13 - Determinando a posição no sistema GPS através de quatro satélites.

Três medidas de distância desse tipo seriam suficientes para determinar a posição tridimensional de um veículo se o relógio do receptor fosse perfeitamente sincronizado com os relógios a bordo dos satélites. Entretanto, a maioria dos receptores GPS é equipada com relógios de quartzo para medir o tempo. Estes relógios não são sincronizados em relação aos relógios atômicos ${ }^{7}$ a bordo dos satélites. Conseqüentemente, o receptor estima, na realidade, uma pseudodistância (distância falsa) de cada satélite. Todas as pseudodistâncias são corrompidas pelo mesmo erro de tempo no relógio do receptor. Esse erro (E) pode ser eliminado matematicamente através da mediçāo de quatro pseudodistâncias ao invés de três. Isso produz um sistema de quatro equações com quatro variáveis:

${ }^{7}$ Um relógio atômico possui uma precisão de um bilionésimo de segundo. São os relógios mais estáveis e apurados disponíveis pela tecnologia, com uma margem de erro de apenas um segundo a cada 70 anos. Cada satélite possui 4 relógios atômicos, que custam US\$ 100.000 cada um. 


$$
\begin{aligned}
& \left(x_{1}-u_{x}\right)^{2}+\left(y_{1}-u_{y}\right)^{2}+\left(z_{1}-u_{z}\right)^{2}=\left(D_{1}-E\right)^{2} \\
& \left(x_{2}-u_{x}\right)^{2}+\left(y_{2}-u_{y}\right)^{2}+\left(z_{2}-u_{z}\right)^{2}=\left(D_{2}-E\right)^{2} \\
& \left(x_{3}-u_{x}\right)^{2}+\left(y_{3}-u_{y}\right)^{2}+\left(z_{3}-u_{z}\right)^{2}=\left(D_{3}-E\right)^{2} \\
& \left(x_{4}-u_{x}\right)^{2}+\left(y_{4}-u_{y}\right)^{2}+\left(z_{4}-u_{z}\right)^{2}=\left(D_{4}-E\right)^{2}
\end{aligned}
$$

onde

$$
\begin{aligned}
& D_{1}=c \times \Delta T_{1} \\
& D_{2}=c \times \Delta T_{2} \\
& D_{3}=c \times \Delta T_{3} \quad \text { e } \quad c=\text { velocidade da luz } \\
& D_{4}=c \times \Delta T_{4}
\end{aligned}
$$

As variáveis $u_{x}, u_{y}$ e $u_{z}$ são as coordenadas da posição do veículo que se desejar calcular e a variável $E$ é o erro introduzido pela falta de sincronização entre os relógios do receptor e dos satélites. Os valores das coordenadas de cada satélite $(x, y$ e $z$ ) estão armazenados em um almanaque de informações em cada receptor GPS. Os dados do almanaque devem ser adquiridos antes do início da navegação com GPS [DOT97].

\subsubsection{Segmentos dos receptores GPS}

O sistema GPS é dividido em três segmentos principais (figura 2.14):
$\rightarrow$ Segmento Espacial;
$\rightarrow$ Segmento de Usuário;
$\rightarrow$ Segmento de Controle. 


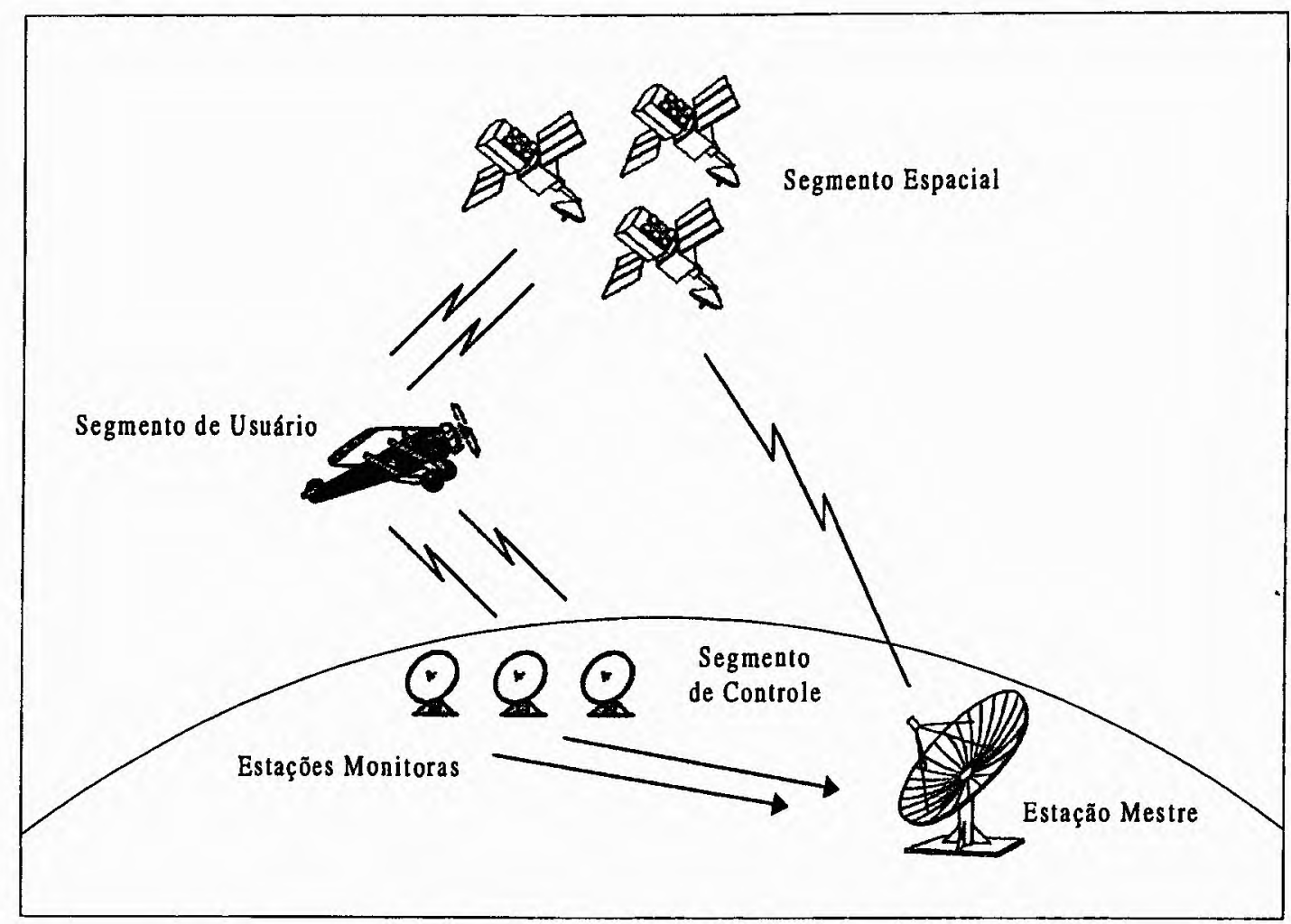

Figura 2.14 - Segmentos do sistema GPS.

\subsubsection{Segmento Espacial}

O propósito do segmento espacial é fornecer pulsos sincronizados e informações orbitais (almanaques) dos satélites para a determinação de posição, velocidade e hora. As informações orbitais consistem de 16 constantes que são enviadas para todos os receptores Navstar, com o intuito de que esses possam determinar onde cada satélite estava quando ele transmitiu os seus sinais[PAZ00].

O segmento espacial é constituído por 21 satélites ativos e 3 de reserva arranjados em 6 planos orbitais. Os satélites do sistema GPS são do tipo Block I (figura 2.15(a)), experimentais, e do tipo Block II (figura 2.15(b)), definitivos. Com essa configuração há, no mínimo, 4 satélites acima da linha do horizonte 24 horas por dia em qualquer ponto da superfície da Terra, fomecendo um posicionamento mundial de três dimensões (latitude, longitude e altitude) e informações de velocidade e de hora. Os satélites estão dispostos a uma altura de 20 mil $\mathrm{Km}$ e têm um período de 12 horas. 


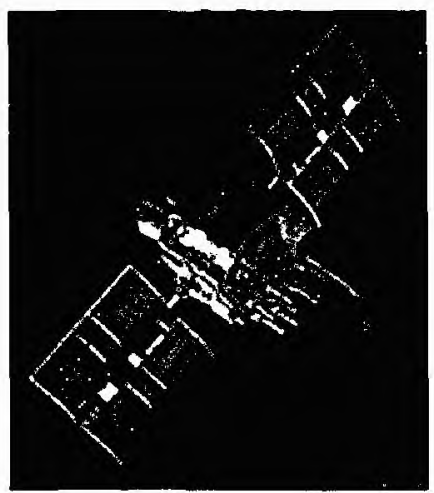

(a)

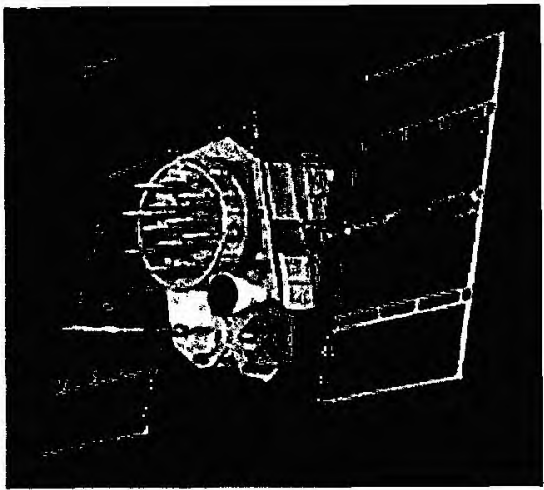

(b)

Figura 2.15 - (a) Satélite Block I e (b) Satélite Block II

Todos os satélites do sistema GPS enviam uma seqüência de números que permitem a um receptor GPS medir a distância de cada satélite. A onda de rádio que carrega uma sequiência de números é chamada de código (code). Os satélites enviam dois códigos: $\mathrm{P}$ (Precision) e CA (Coarse Acquisition). O código P é uma sequiência de números tão longa que ela se repete somente uma vez a cada sete dias. Já no código CA a seqüência é tão curta que se repete a cada 1 milisegundo.

Todos os satélites enviam os códigos em duas freqüências: $1227,6 \mathrm{MHz}$, chamada de L2 (Link 2) e 1575,42, chamada de L1 (Link 1). O código P trafega em ambas as freqüências enquanto que o código CA trafega somente na frequiência $L 1$. Devido à freqüuencia mais alta, o código $\mathrm{P}$ fornece mais precisão na determinação das coordenadas. O Departamento de Defesa dos EUA (DoD) restringiu o uso do código $\mathrm{P}$ somente para fins militares, sobrepondo ao mesmo uma nova modulação, o código Y, que é conhecida por AS (Anti-Spoofing). Além do AS, o DoD decidiu pôr uma outra restrição, conhecida como Selective Availability (SA), incluindo um erro proposital nas mensagens enviadas pelos satélites [LOG92]. Com a idéia de eliminar os efeitos sistemáticos dos erros impostos, foi desenvolvida uma técnica específica de posicionamento com o uso do código CA, o DGPS (Differential Global Positoning System). Tal técnica será apresentada na seção 2.6.4.

Os sinais gerados pelos satélites contêm um "código de identidade", dados efêmeros (de status) e dados do almanaque. O "código de identidade" identifica qual satélite está transmitindo. Cada satélite é identificado pelo seu PRN, de 1 a 32, e este é o número mostrado no receptor para indicar de qual(is) satélite(s) ele está recebendo informações. Os dados efêmeros são constantemente transmitidos e contêm informações de status do satélite 
(operacional ou não), hora, dia, mês e ano. Os dados de almanaque dizem ao receptor onde procurar cada satélite a qualquer momento do dia.

\subsubsection{Segmento de Usuário}

O propósito do segmento de usuário é processar a hora e as informações de posição provenientes de quatro ou mais satélites, para obter a velocidade e a posição precisa do veículo. Um receptor GPS pode ser dividido em três componentes principais: antena, unidade de processamento (que recebe e processa os sinais dos satélites) e unidade de display (que possibilita uma interface entre o usuário e o sistema GPS).

Um receptor GPS somente "escuta" os sinais transmitidos pelos satélites, não interagindo ou fornecendo nenhuma realimentação. Portanto, o número de usuários simultâneos é ilimitado. O receptor fornece automaticamente uma posição precisa sem a necessidade de entrada de dados ou intervenção humana.

A primeira tarefa realizada pelo receptor GPS quando ele é ligado é o recebimento de informações orbitais de todos os satélites. Elas são conhecidas como almanaque. Cada satélite possui o almanaque completo de todo o sistema; logo, um satélite específico não precisa estar visível para que o receptor saiba a sua posição. $O$ tempo para que um receptor receba todo o almanaque é de aproximadamente 12 minutos e é conhecido como tempo para a primeira fixação (TTFF - Time to First Fix). Depois disso, ele armazena as informações do almanaque em sua memória não-volátil, reduzindo o tempo de lock (tempo necessário para localizar três satélites e determinar sua posição).

Se um receptor não é utilizado por mais de seis meses ou é movido a uma distância superior a $480 \mathrm{Km}$ desde o último ponto a partir do qual ele realizou o TTFF, o almanaque armazenado na memória é atualizado[LET98]. Quando o receptor é desligado, ele armazena as coordenadas da última posição obtida em sua memória não-volátil. Ao ser novamente ligado, a última coordenada armazenada torna-se sua posição estimada. A memória nãovolátil armazena o último conjunto de constantes do almanaque, definindo a localização de todos os satélites em funcionamento na constelação corrente. Essas constantes podem ser utilizadas em uma nova navegação para determinar quais satélites estão acima do horizonte e quais os quatro satélites que estão em posições favoráveis para fornecer uma localização 
precisa. O receptor GPS possui um relógio de cristal de quartzo que continua operando mesmo quando o receptor é desligado.

\subsubsection{Segmento de Controle}

A função do segmento de controle é rastrear e monitorar os satélites do sistema GPS. Este segmento é composto por 5 estações de monitoramento no solo, sem operadores. Quatro estações de monitoramento capturam sinais de um determinado satélite, ao mesmo tempo, calculando a que distâncias estão desse satélite. As distâncias obtidas são transmitidas para a estação-mestre de controle. A estação-mestre processa as distâncias obtidas pelas estações de monitoramento, para determinar as constantes orbitais e os fatores de correção nos relógios atômicos a bordo de cada satélite. Tais informações são atualizadas em cada satélite, uma vez ao dia, por antenas posicionadas ao redor da Terra.

A estação-mestre de controle é um computador operado pela Força Aérea dos Estados Unidos, situado no Consolidated Space Operations Center (CSOC). O CSOC, que também serve para muitos satélites militares, está localizado em uma área de segurança no Colorado.

\subsubsection{Precisão do Sistema GPS}

Existem vários fatores que influenciam na precisão de um receptor GPS, dentre eles:

$\rightarrow$ Disponibilidade seletiva;

$\rightarrow$ Interferência ionosférica;

$\rightarrow$ Geometria dos satélites;

$\rightarrow$ Reflexão de sinais.

\subsubsection{Disponibilidade Seletiva (Selective Availability)}

Um erro é introduzido através da mudança de hora em que o código CA é difundido, causando uma falta de sincronização entre os satélites. O erro limita a precisão da informação do posicionamento do satélite enviada aos receptores GPS. A precisão para uso civil varia, randonicamente, entre 15 e $100 \mathrm{~m}$. O usuário nunca sabe a quantidade de erro introduzida e em qual direção ele ocorreu. Disponibilidade seletiva é implementada de forma que, em $95 \%$ 
das vezes, a precisão do receptor varia entre 15 e $100 \mathrm{~m}$ e, nos outros $5 \%$, o erro introduzido chega a $300 \mathrm{~m}$.

Atualmente, a inserção do erro proposital está suspensa. O Presidente dos Estados Unidos, no dia 2 de maio de 2000 , tomou esta decisão com base nas recomendações do Secretário de Defesa e em coordenação com os Departamentos de Estado, Transporte, Comércio e com o diretor da Central de Inteligência. O Secretário alegou que as áreas de pesquisas científicas, o transporte nacional, os interesses comercias e todas as demais áreas que fazem uso do GPS poderiam obter melhor aproveitamento e desempenho com o desligamento da AS. Alegou-se também que o impacto desse desligamento na segurança nacional seria mínimo.

Com essa medida, os usuários civis do receptor GPS podem obter sua localização com uma precisão dez vezes maior. Foram realizados vários testes em vários estados nos Estados Unidos para verificar o ganho de precisão sem a disponibilidade seletiva. Um teste realizado no National Oceanic and Atmospheric Administration (NOAA) pela National Geodetic Survey $^{8}$ (NGS), consistiu em coletar dados de um receptor GPS 24 horas antes do desligamento da SA e 24 horas depois. O gráfico da figura 2.16 [MILO0] mostra que $95 \%$ dos pontos coletados pelo receptor GPS antes do desligamento do SA estão dentro de um raio de $45 \mathrm{~m}$ e a figura 2.17 [MIL00] mostra que $95 \%$ dos pontos coletados depois do desligamento estão dentro de um raio de $6,3 \mathrm{~m}$. Os dados foram coletados por um receptor Ashtech Z-12, utilizando ambas as freqüências L1 e L2 e incorporando as correções ionosféricas (seção 2.6.3.2).

\footnotetext{
${ }^{8}$ Sub área da NOAA que define e gerencia o Sistema de Referência Espacial Nacional (The National Geodetic Survey-NGS).
} 


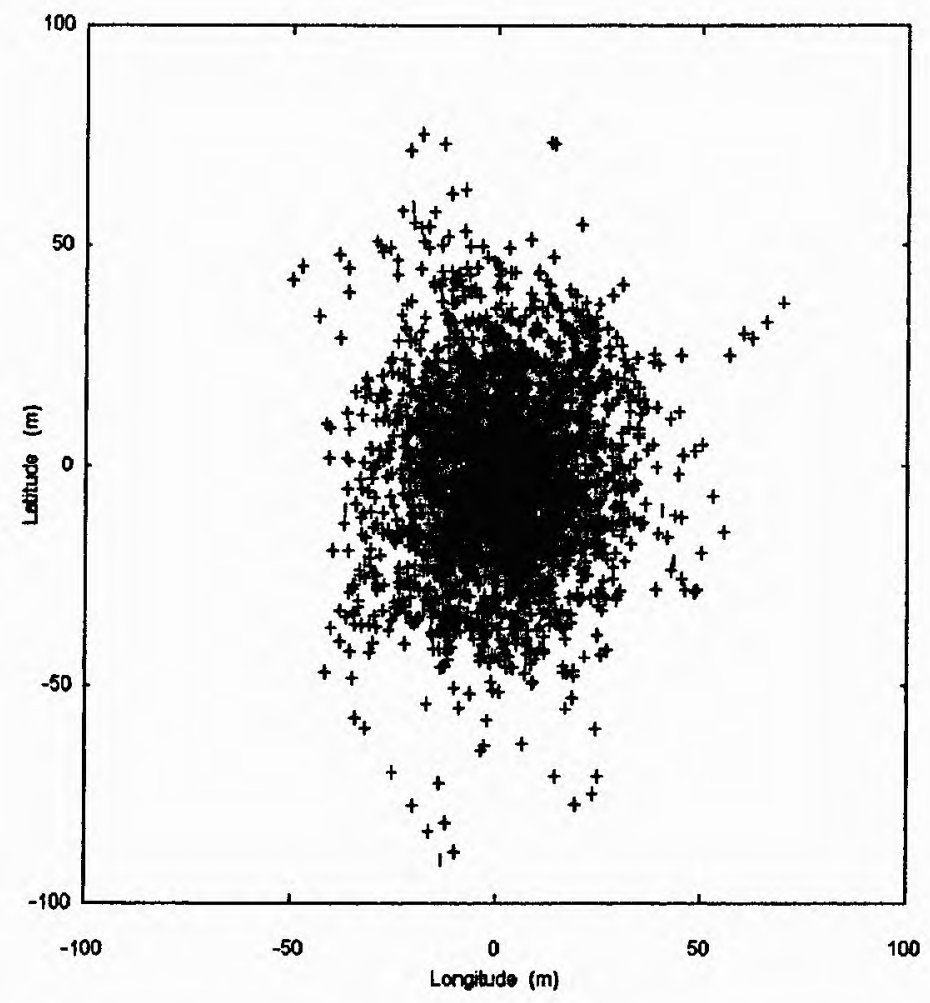

Figura 2.16 - Dados coletados com SA no dia 1 de maio de 2000,24 hs antes do desligamento.

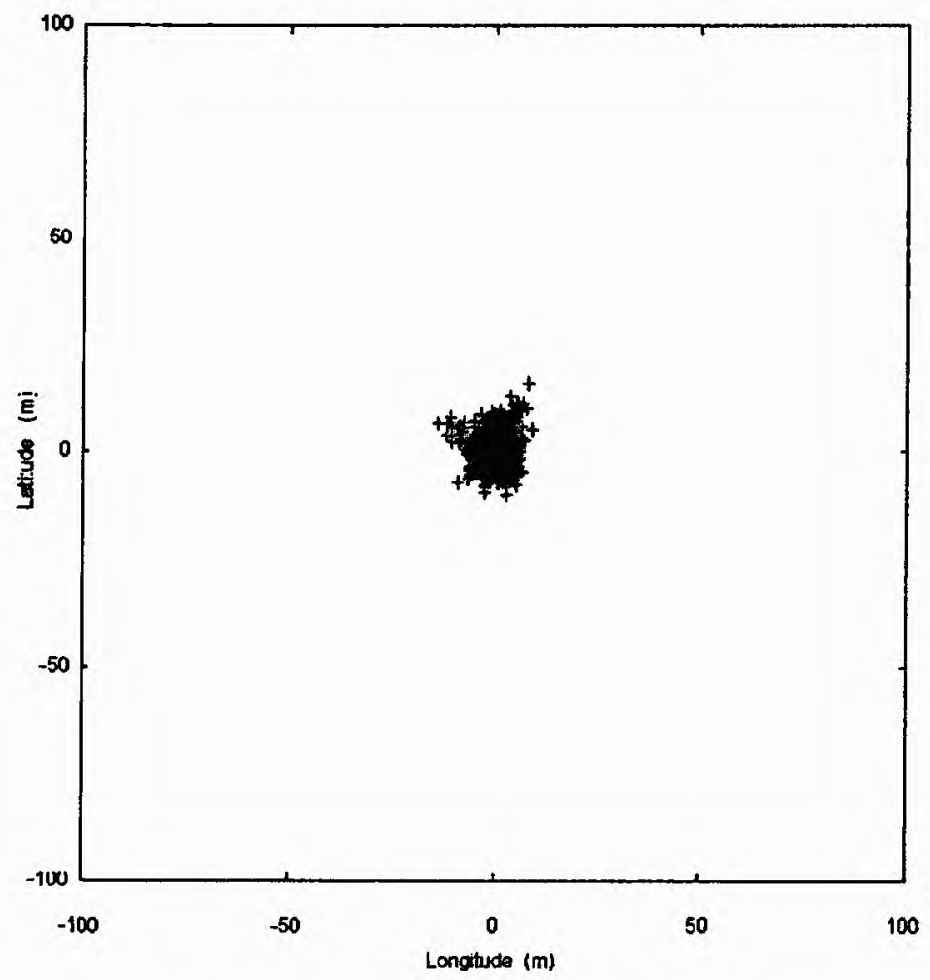

Figura 2.17 - Dados coletados sem SA no dia 3 de maio de 2000, 24 hs depois do desligamento. 


\subsubsection{Interferência Ionosférica}

A ionosfera é uma camada da atmosfera da Terra que fica entre 80 e $400 \mathrm{Km}$ acima da superfície. Quando os sinais provenientes dos satélites atravessam a ionosfera, eles sofrem uma curvatura e um atraso. O tempo total de atraso é inversamente proporcional ao quadrado da freqüência de transmissão dos sinais. Contudo, as duas freqüências de transmissão dos satélites (L1 e L2) podem ser utilizadas para realizar uma compensação no atraso. Cada freqüência resulta em um tempo de atraso diferente. Conseqüentemente, pode ser realizada uma simples correção matemática em um receptor de códigos $\mathrm{P}$ para extrair os atrasos ionosféricos. Já em receptores de códigos CA, que capturam somente sinais L1, não se pode utilizar esse método. Esses receptores modelam matematicamente o comportamento da ionosfera, usando um conjunto de coeficientes polinomiais que corrigem o erro provocado pela ionosfera em até $50 \%$, quando esses valores são comparados com aqueles não-corrigidos.

\subsubsection{Geometria dos Satélites}

A geometria dos satélites, ou constelação, refere-se às posições dos satélites relativas ao posicionamento do usuário. A quantidade de erro introduzida pela geometria dos satélites é denominada DOP (Dilution of Precision). Existem vários componentes da DOP: vertical (VDOP), horizontal (HDOP), tempo (TDOP), posição (PDOP) e geometria (GDOP). Algumas posições de satélites garantem mais precisão. O receptor GPS calcula cada componente para cada combinação de quatro satélites e então utiliza os sinais provenientes dos quatro satélites que fornecem uma PDOP menor. Quanto maiores os valores numéricos dos fatores (PDOP, HDOP, VDOP, TDOP, GDOP), pior a qualidade da determinação correspondente; os valores para DOP que fornecem uma boa precisão variam entre 1 e 3 . Quando o receptor calcula uma DOP maior que 6, ele nem tenta calcular a posição do usuário [LOG92].

\subsubsection{Reflexão de Sinais}

Em condições ideais, os sinais provenientes dos satélites seguem um único caminho, diretamente para o receptor GPS. Se o sinal é refletido por alguma barreira, pode-se ter mais de um caminho até o receptor, provocando um efeito de retardo do sinal. Esse efeito é chamado de multipath. Os sinais chegam: dos satélites e de reflexões em objetos como uma 
montanha. Atualmente, somente receptores especiais, pesados e de custo alto podem detectar e eliminar os sinais refletidos. O receptor comum não consegue diferenciar os sinais diretos dos sinais refletidos. Se o receptor utilizar os sinais refletidos para determinar a posição, esta será errada.

Uma vez que os sinais transmitidos podem ser absorvidos, refletidos ou refratados por objetos próximos à antena do receptor ou entre a antena e o satélite, recomenda-se que o horizonte em torno da antena esteja desobstruído acima de 15 graus. Deve-se evitar locais próximos a estações de transmissão de microondas, radares, antenas rádio-repetidoras e linhas de transmissão de alta voltagem, por representarem fontes de interferência para os sinais GPS.

\subsubsection{GPS Diferencial}

A precisão fornecida por um sistema GPS não é satisfatória para alguns usuários civis, como pilotos de aviōes e navios. A solução para uma melhor precisão é fomecida pelo sistema GPS diferencial (DGPS - Differential GPS) que garante uma precisão entre $2 \mathrm{~cm} \mathrm{e}$ $15 \mathrm{~m}$.

O DGPS utiliza dois métodos para corrigir os erros de posição:

$\rightarrow$ Correção em tempo real;

$\rightarrow$ Correção pós-processamento.

\subsubsection{Correção em Tempo Real}

O sistema DGPS com correção em tempo real é constituído por dois receptores GPS, sendo que um receptor atua como uma estação monitora e o outro é utilizado pelo usuário. Um receptor é colocado de forma fixa em um ponto com coordenadas previamente estabelecidas (estação monitora), enquanto o outro (usuário) é situado no local cujas coordenadas deseja-se saber. Existem programas computacionais específicos que corrigem as posições desejadas utilizando os dados obtidos pelos receptores da estação monitora e do usuário.

Os dois receptores devem estar recebendo informações de posição dos mesmos satélites e a distância entre a estação monitora e o usuário não pode ser superior a $100 \mathrm{Km}$. Para uma maior cobertura, são necessárias várias estações espalhadas pela Terra. 
Como a estação monitora conhece a sua posição verdadeira em relação aos satélites, ela conhece a quantidade de erro introduzida pela disponibilidade seletiva. A estação monitora é equipada com um transmissor de rádio e, após computar a quantidade de erro introduzida, ela difunde essa informação na freqüência do sistema de rádio-navegação Loran C. O sistema DGPS, do lado do usuário, possui um conversor com uma antena Loran $\mathrm{C}$ que captura a informação, enviando-a para o receptor GPS. Este, por sua vez, aplica a informação de correção à posição obtida.

\subsubsection{Correção Pós-processamento}

O método de correção pós-processamento é a maneira mais fácil e de menor custo para se obter a precisão de um sistema DGPS. Como o próprio nome já diz, a correção é realizada após a viagem do usuário. Este sistema requer um receptor que registre mais informações do que o convencional. Quando o usuário armazena as coordenadas de um waypoint, o receptor registra a hora exata em que elas foram armazenadas e os satélites que foram utilizados para a obtenção desse waypoint. Com o decorrer da viagem do usuário, vários waypoints serão armazenados para documentar a rota seguida.

No fim da viagem, todas as informações armazenadas no receptor são transferidas para um computador. O software de correção analisa cada coordenada, a hora e os satélites e então recalcula as coordenadas de modo a obter uma melhor precisão. O pós-processamento é mais adequado para usuários que queiram apenas documentar com precisão o caminho viajado.

\subsubsection{Sistema GLONASS}

O sistema GLONASS (GLObal'naya NAvigatsionnaya Sputnikovaya Sistema) é um sistema de navegação equivalente ao sistema GPS, desenvolvido pela Rússia. O sistema GLONASS fornece a mesma precisão que o sistema Navstar, exceto pelo fato de não existir disponibilidade seletiva. Um receptor GPS Navstar não consegue capturar os sinais provenientes do sistema russo. Porém, já foi desenvolvido um receptor capaz de capturar sinais dos dois sistemas, o que implica em um sistema com uma constelação de satélites duas vezes maior, facilitando a tarefa de se encontrar uma geometria de satélites adequada para se obter uma melhor precisão. A desvantagem deste receptor é o alto custo de aquisição. A tabela 2.2 mostra uma breve comparação entre o sistema GLONASS e o Navstar. 
Tabela 2.2 - Comparaçăo entre os sistemas GPS e o GLONASS

\begin{tabular}{|c|c|c|}
\hline Constelação & $21+3$ & $21+3$ \\
\hline Número de órbitas & 6 & 3 \\
\hline Altitude orbital & $20.180 \mathrm{Km}$ & $19.100 \mathrm{Km}$ \\
\hline Periodo orbital & $12 \mathrm{~h}$ & $11 \mathrm{~h} 15 \min$ \\
\hline Inclinação orbital & $\begin{array}{l}63^{\circ} \text { (Block I) } \\
55^{\circ} \text { (Block II) }\end{array}$ & $64.8^{\circ}$ \\
\hline Frequiência L1 & $1575,72 \mathrm{MHz}$ & $1602,56-1615,50 \mathrm{MHz}$ \\
\hline Freqüêtencia L2 & $1227,60 \mathrm{MHz}$ & $1246,44-1256,50 \mathrm{MHz}$ \\
\hline Identificação dos satélites & Códigos C/A individuais' . & Freqüencias individuais \\
\hline $\begin{array}{l}\text { Precisão de posição para uso } \\
\text { civil }\end{array}$ & $100 \mathrm{~m}$ & $100 \mathrm{~m}$ \\
\hline Taxa de bits & $1,023 \mathrm{Mb} / \mathrm{s}$ & $0,511 \mathrm{Mb} / \mathrm{s}$ \\
\hline
\end{tabular}

\subsubsection{Vantagens de'Sistemas com Bases no Espaço}

Os sistemas de rádio-navegação com bases no solo têm sido utilizados por mais de 50 anos, fornecendo uma cobertura mundial confiável para os navegadores. Porque estão sendo substituídos por sistemas com transmissores no espaço? O principal motivo da substituição é a freqüência com que os sinais são transmitidos. Tanto as freqüências baixas quanto as freqüências altas são insatisfatórias. As ondas transmitidas em baixas frequiências sofrem interferências causadas pela camada ionosférica, embora ofereçam larga cobertura. É o caso do sistema Omega que cobre quase totalmente a Terra com apenas oito estações transmissoras no solo. Mas o sistema Omega, como os outros sistemas de rádio-navegação, não garante uma navegação precisa, uma vez que as ondas por ele transmitidas não podem ser moduladas com muitas informações úteis. Além disso, seus sinais são refletidos na camada ionosférica.

Por outro lado, os sistemas que transmitem sinais em altas freqüências fornecem uma melhor precisão. $O$ problema das ondas de alta freqüência é que essas atravessam a camada ionosférica. Tais sistemas fornecem uma cobertura limitada apenas aos navegadores que estão 
em visada direta com as estações transmissoras. Mesmo com os transmissores em torres de até $90 \mathrm{~m}$ de altura, a cobertura alcançada é de apenas $64 \mathrm{Km}$ de diâmetro. Para se obter uma cobertura mundial, seriam necessários milhões de transmissores no solo e no mar, espalhados pela Terra. A solução para resolver alguns desses problemas é utilizar altas freqüências difundidas de transmissores acima da superfície da Terra. Transmissores localizados em altitudes elevadas podem fornecer uma cobertura quase mundial, emitindo ondas que penetram na camada ionosférica de cima para baixo, fomecendo uma navegação de alta precisão [LOG92].

\subsection{Outros Projetos de Pesquisa Relacionados}

O sistema GPS Navstar fornece atualmente, sem a disponibilidade seletiva, um posicionamento preciso de um ponto em qualquer parte do mundo. O sistema GPS criou novas oportunidades para o desenvolvimento e aplicações de veículos aéreos não tripulados (UAV - Unmanned Aerial Vehicle). Já foi comprovado tecnicamente e economicamente que é viável a substituição de aeronaves tripuladas por UAVs em várias aplicações.

\subsubsection{MAFV - Multi-purpose Autonomous Flight Vehicle}

Um estudo dos sistemas de sensores necessários para cada uma das aplicações e missões citadas na seção 2.2.1 sugeriu o desenvolvimento de um único veículo aéreo para vários propósitos. Este veŕculo é denominado MAFV (Multi-purpose Autonomous Flight Vehicle), também conhecido como Jabiru. A figura 2.18 ilustra o veículo MAFV que está sendo desenvolvido na Austrália. Ele foi projetado de maneira modular, com interfaces padronizadas para acomodar a diversidade de cargas úteis necessárias e os vários tempos de duração de cada missão [VAL96]. Os módulos de navegação/orientação, cargas úteis, combustível e bateria são configurados para possibilitar a otimização das missões desejadas. Todas as configurações do sistema MAFV utilizam um lançador (catapulta), um sistema de recuperação de falhas e uma estação receptora de dados. 


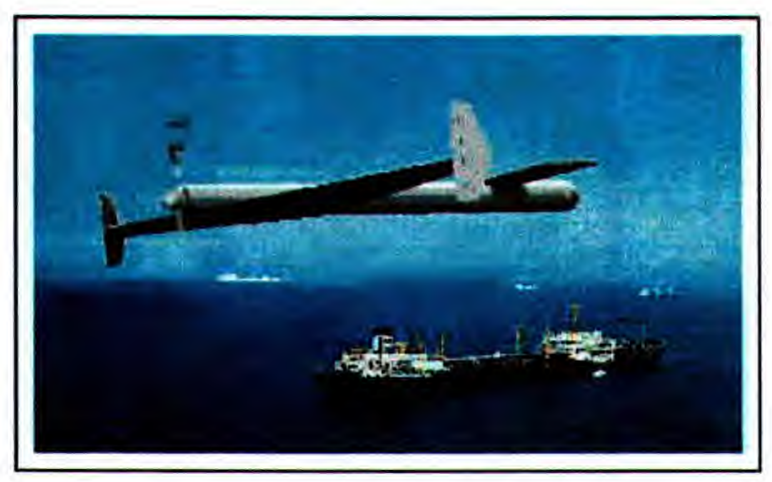

Figura 2.18 - O veículo MAFV

\subsubsection{Funcionamento do Sistema MAFV}

O veículo MAFV pode determinar sua posição real no espaço com uma precisão de $8 \mathrm{~m}$, em tempo real, usando um sistema GPS diferencial para navegação e um piloto automático. Através da comparação com as coordenadas de waypoints pré-programadas, o sistema de gerenciamento de vôo manobra o veículo ao longo da trajetória previamente estabelecida. Os sensores a bordo do MAFV realizam suas leituras ${ }^{9}$, armazenando-as, para depois serem transmitidas para uma estação terrestre, via satélite. Após a missão ser completada, o veículo MAFV retorna automaticamente para um waypoint pré-determinado, onde o controle é passado ou para um controlador manual (rádio-controle) ou para um sistema de pouso automático[VAL96].

Para a maioria das missões, o sistema MAFV utiliza o sistema GPS na determinação de sua posição. Em caso de falha do sistema GPS, é utilizado o sistema de navegação inercial. O veículo MAVF, equipado com um receptor GPS, mede sua distância de quatro satélites para determinar sua posição tridimensional e sua velocidade. $O$ veículo recebe também a hora de cada satélite para corrigir o seu relógio interno.

O usuário do sistema MAFV pode definir o seu plano de vôo através de uma janela gráfica interativa que ainda está sendo desenvolvida. Essa interface gráfica possibilita a definição de waypoints em um mapa digital. O plano de vôo consiste de coordenadas de waypoints considerando a velocidade, a altitude, a taxa de climb, etc.

\footnotetext{
${ }^{9}$ Dependente de cada aplicação. Por exemplo, no caso de monitoramento agrícola, a câmera digital é ativada para a coleta de fotografias.
} 
Após a definição do plano de vôo, este é carregado no computador de bordo. O plano de vôo pode ser modificado durante o vôo através de comunicação via satélite. A figura 2.19 [THO94] ilustra o esquema da unidade de gerenciamento de vôo e os sistemas conectados a ela. Os requisitos para a navegação do veículo MAFV dependem de cada missão. Entretanto, a maioria das missões requer um mesmo conjunto mínimo de requisitos.

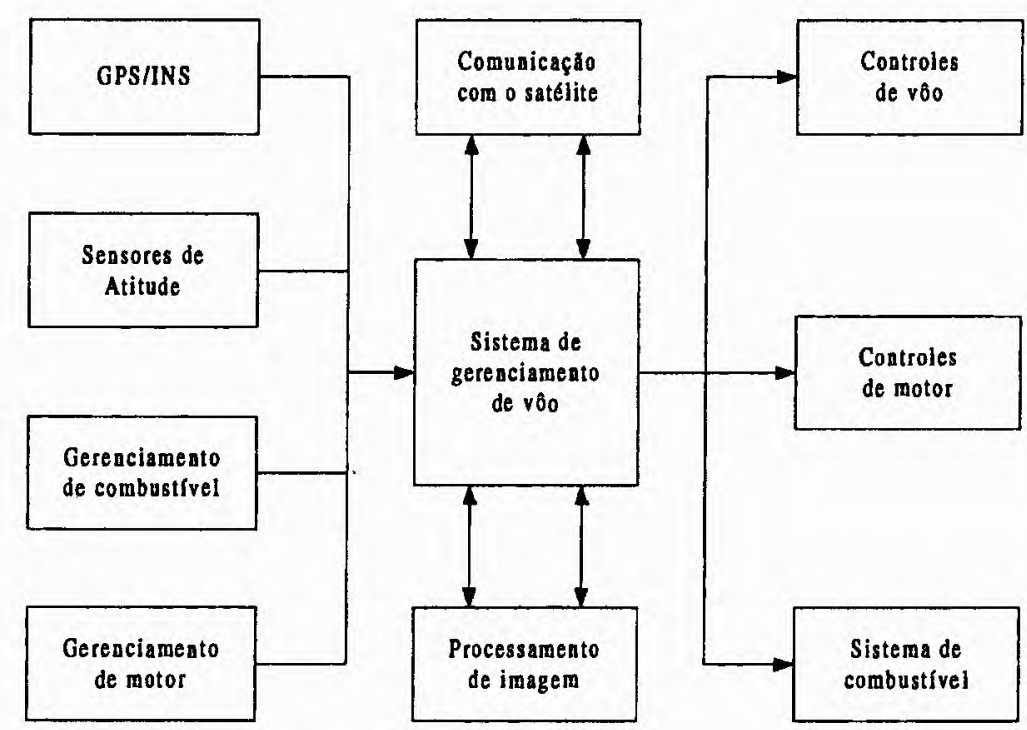

Figura 2.19-Esquematização do sistema de gerenciamento dẹ vôo do veículo MAFV

Muitas missões do sistema MAFV requerem uma comunicação contínua. $O$ sistema emprega comunicação via satélite para possibilitar a transmissão de dados do veículo para a base, facilitando também a reprogramação de planos de vôo. Para tanto, são utilizados os satélites de comunicação já existentes. Os dados a serem transmitidos consistem em imagens (fotografias aéreas), localização do receptor GPS de onde a foto foi capturada, hora e qualquer outro dado necessário do sistema de vôo. As imagens são armazenadas no veículo MAFV em uma memória a bordo. Essas imagens são comprimidas e transmitidas via sistema de satélites IMARSAT [THO94].

O sistema de gerenciamento de vôo denominado AFCS (Automatic Flight Control System) foi desenvolvido especialmente para controlar o MAFV. O AFCS fornece um controle completo para todos os tipos de operações do veículo. O seu hardware é baseado na série 68000 de microcontroladores da Motorola, e opera em $16 \mathrm{MHz}$. O processador está conectado a 64 Kbytes de RAM e ROM. A baixa velocidade e estabilidade do veículo Jabiru facilita o uso de um hardware de baixo desempenho, contribuindo para manter o custo extremamente baixo. 
O sistema é completamente programável e permite ao usuário escrever programas em uma linguagem de programação de alto nível. A linguagem de programação é usada em todos os níveis do sistema, tanto para o controle de baixo nível das superfícies controladoras quanto para o gerenciamento da missão em si.

\subsubsection{Projeto Aerosonde}

O projeto Aerosonde foi desenvolvido em parceria com o Environment System and Services, em Melbourne, e o Australian Bureau of Meteorology. Este projeto está centrado na construção de um avião robô para monitoramento ambiental de longo alcance. Ele pode ser adaptado para outras aplicações que exigem pequena carga útil [HOL99]. O seu desenvolvimento foi centrado no reconhecimento meteorológico e ambiental do oceano, podendo investigar furacões e tempestades. Recentemente, essa aeronave entrou na história quando cruzou o Oceano Atlântico, da Austrália para o EUA, passando por furacões, sem qualquer interferência humana.

O Aerosonde é completamente autônomo, capaz de decolar e pousar sem qualquer interferência humana. A figura 2.20 [HOL99] ilustra a aeronave Aerosonde. Para a navegação, é utilizado um receptor GPS. Existe, entretanto, um mecanismo para sobrepor os comandos gerados pelo computador de bordo, caso seja necessária a intervenção humana. A aeronave possui sensores para determinar a velocidade do vento, pressão, altura, temperatura e umidade com o intuito de realizar o monitoramento ambiental.

O Aerosonde faz a comunicação com a estação de solo utilizando um modem de UHF com raio máximo de alcance de $150 \mathrm{Km}$. A estação móvel está ligada a uma estação fixa em Melborne através de telefonia por satélite e a estação fixa pode comandar a aeronave.

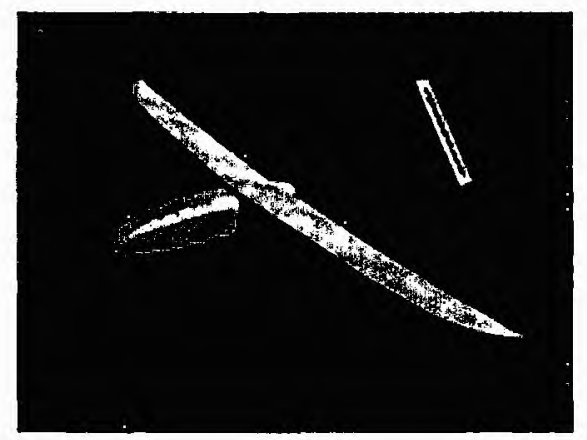

Figura 2.20 - A aeronave do projeto Aerosonde 


\subsubsection{Projeto UAV - Uninhabited Aerial Vehicles}

É um projeto de veículos aéreos sem tripulação para a realização de missões aéreas de baixos risco e custo. Este projeto está sendo desenvolvido pela Universidade de Michigan e possui três modos de operação: por controle remoto, semi-autônomo e completamente autônomo. O projeto tem como objetivo a criação de uma bancada de testes para conduzir pesquisas em UAVs envolvendo vôo com controle adaptativo e reconfigurável e algoritmos para o cumprimento de missões automáticas e para o planejamento de trajetória. Também é objetivo do projeto a demonstração do uso da tecnologia UAV de baixo custo desde o projeto até a operação autônoma. As principais aplicações previstas nesse projeto são:

† Obtenção de imagens para a agricultura;

† Monitoramento de tráfego;

$\downarrow$ Obtenção de dados meteorológicos;

$\downarrow$ Missões de reconhecimento para coleta de informações.

\subsubsection{Projeto AURORA}

O Projeto AURORA (Autonomous Unmanned Remote Monitoring Robotic Airship) está sendo desenvolvido pelo Laboratório de Robótica e Visão do CTI (Centro Tecnológico para Informática) em Campinas, São Paulo.

Este projeto tem a finalidade de disponibilizar um dirigivel não tripulado, semiautônomo, para aquisição de dados e imagens para o monitoramento aéreo de áreas de interesse, monitoramento de tráfego, planejamento urbano, inspeções arqueológicas, pesquisa ambiental, monitoramento e sensoriamento de florestas, estudos agrícolas, caracterização de plantas e identificação de poluentes na atmosfera.

O modelo selecionado de dirigível foi o AS800 da Airships, ilustrado na figura 2.21 [ELF98]. A meta do projeto AURORA é o desenvolvimento de um robô dirigível com um nível de autonomia significativo durante todas as fases de sua operação. Isso inclui habilidade para realizar missões, navegação automática, diagnóstico de falhas e sua recuperação, avaliação em tempo real dos sensores e replanejamento das tarefas. 


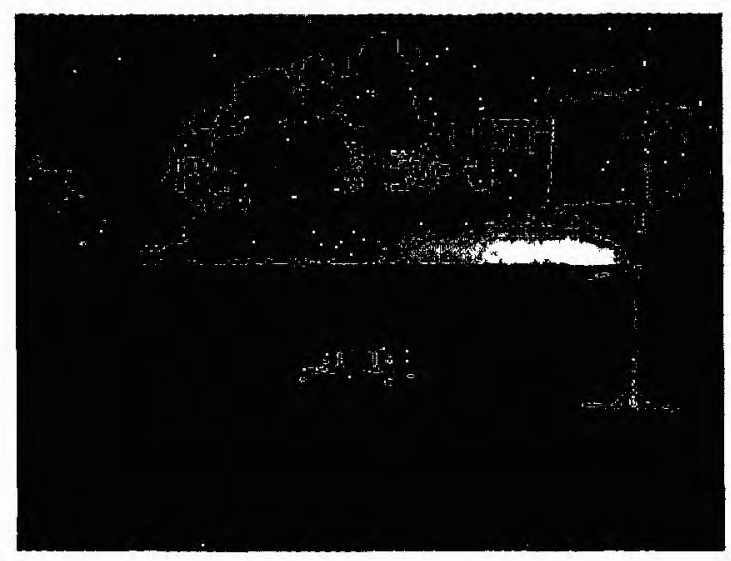

Figura 2.21 - Dirigível AS800

O processo de construção e aprimoramento do projeto AURORA foi dividido em três fases, conforme a tabela 2.3 .

Tabela 2.3 - Etapas do projeto AURORA

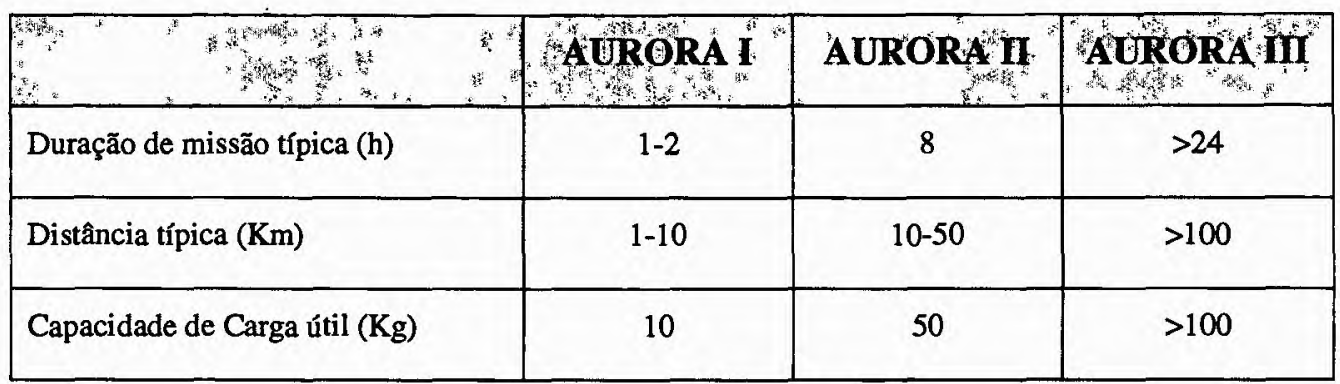

O dirigível é equipado com um controle de bordo e um sistema de navegação, incluindo sensores internos, hardware e software. Os sensores internos da aeronave são:

† Bússola;

$\rightarrow$ Acelerômetro;

† Inclinômetro;

$\downarrow$ Giroscópio;

$\rightarrow$ Receptor GPS.

Câmeras de vídeo foram montadas na gôndola do dirigível para fornecer imagens aéreas ao operador, servindo para a navegação visual. A bússola, o inclinômetro e o receptor GPS estão diretamente conectados ao computador que é do tipo PC 104. Todos os controles de navegação e sensores (velocidade do motor, altitude, sensor de ângulo de ataque, velocidade do vento, acelerômetros, combustível e nível de bateria, e temperatura de motor) 
estão conectados ao PC e os atuadores (motores e controles de superfície) são conectados ao microprocessador.

O dirigível possui um sistema de comunicação composto de links de rádio, os quais transmitem dados e comandos entre o dirigível e a estação base. Inclui também links de vídeo para transmissão das imagens capturadas pelas câmeras montadas a bordo. Uma estação móvel composta de uma infra-estrutura de processamento e comunicação, um mastro de arrasto e um veículo móvel para transporte complementam o equipamento [ELF98].

Quanto ao software de baixo nível foi escolhido o Linux como software básico com um kernel reduzido. A complexidade dos sistemas-robôs requer alta interatividade e o uso de múltiplos threads para habilitar algumas funções e desabilitar outras, de forma independente.

A interface homem-máquina fornece a comunicação e a visualização dos instrumentos a bordo do dirigivel. Como parte da interface, foi desenvolvido um simulador do dirigível, com base no modelo físico permitindo a realização de teste de vôo, decolagem e pouso através da Internet.

\subsection{Considerações Finais}

Neste capítulo foram revistos os conceitos relacionados a uma aeronave da fase III do projeto ARARA. Foram apresentados os conceitos de sistemas de navegação e piloto automático, sistemas fundamentais na implementação da fase III do referido projeto. Além disso, foram mostrados conceitos sobre o sistema GPS, componente de fundamental importância para o sistema de navegação. Este sistema será utilizado para fornecer a posição da aeronave durante o seu vôo autônomo. Discutiu-se ainda, de forma breve, outros projetos de pesquisa em andamento, os quais também possuem envolvimento com aeronaves autônomas.

No próximo capítulo serão definidos os requisitos funcionais do sistema implementado neste projeto. 


\section{Capítulo 3}

\section{Sistema SiNaCoM}

\subsection{Considerações Iniciais}

Neste capítulo são apresentados a análise de requisitos, a especificação e o projeto do sistema SiNaCoM da fase III do projeto ARARA. O SiNaCoM foi dividido em dois módulos: Planejador de Missão e Sistema de Navegação. Para efeitos de clareza, a definição dos diagramas de fluxo de dados foi realizada separadamente para cada módulo.

Na seção 3.2 é definido o Sistema de Navegação do projeto ARARA e suas funções são delimitadas. Na seção 3.3 foi realizada uma análise de requisitos de todo o sistema. Na seção 3.4 são apresentados a configuração da aeronave na fase III do projeto ARARA, o receptor GPS selecionado para esta fase, suas principais características e as principais sentenças da interface NMEA utilizadas por este receptor. A descrição detalhada do conteúdo de cada sentença NMEA pode ser encontrada do apêndice $A$.

A seção 3.5 apresenta a notação utilizada nos diagramas de fluxo de dados e nos diagramas de estados. O diagrama de contexto e o diagrama de fluxo de dados de nível 1do sistema SiNaCoM são apresentados na seção 3.6. Os diagramas de fluxo de dados e a descrição de todas as funções dos módulos Planejador de Missão e Sistema de Navegação são detalhados separadamente nas seções 3.7 e 3.8, respectivamente. O Sistema de Navegação, por ser um sistema de tempo real, também foi especificado em diagramas de estado. Estes diagramas são apresentados na seção 3.9. As considerações finais deste capítulo são apresentadas na seção 3.10 . 


\subsection{Delimitação das Funções do Sistema de Navegação}

As funções do piloto automático podem ser divididas em funções de orientação $e$ controle (seção2.4.1). A fronteira entre estas funçōes dificilmente pode ser definida devido às interações funcionais, operacionais e de equipamentos que elas podem compartilhar.

Neste trabalho, o sistema de orientação e o sistema de controle são definidos separadamente. O sistema de orientação, juntamente com o sistema de posicionamento global (GPS), compõe o Sistema de Navegação. O Sistema de Controle está sendo desenvolvido separadamente em outro trabalho de mestrado.

O Sistema de Navegação tem como função guiar a aeronave ao longo de uma trajetória definida previamente pelo usuário. Para tal, ele calcula manobras, a partir dos dados obtidos do receptor GPS e de sensores, e as envia ao Sistema de Controle. Este, por sua vez, em resposta às manobras, deve atuar nas superfícies de controle da aeronave, posicionando-a na posição desejada.

\subsection{Requisitos Funcionais do Sistema}

O sistema de navegação de aeronaves da fase III do Projeto ARARA (seção 2.1) foi denominado SiNaCoM (Sistema de Navegação e Controle de Missão). As funções do sistema SiNaCoM podem ser agrupadas em dois módulos: Planejador de Missão (módulo da estação no solo) e Sistema de Navegação (módulo da aeronave), cujos requisitos funcionais são apresentados a seguir.

\subsubsection{Requisitos Funcionais do Módulo Planejador de Missão}

† O sistema deve apresentar ao usuário uma interface gráfica para a visualização de mapas com extensões bmp e gif.

$\dashv \mathrm{O}$ usuário pode inserir marcos (landmarks) e waypoints em qualquer ponto do mapa.

O usuário pode selecionar um mapa e traçar sobre ele uma rota a ser seguida pela aeronave. A rota pode ser composta por um waypoint inicial, um ou mais waypoints 
intermediários e um waypoint final. A rota é visualizada como waypoints interligados por retas.

† A área para vôo delimitada pelo usuário deve estar dentro da área de alcance da aeronave.

$\downarrow$ A altitude de um waypoint inserido na rota deve estar acima de um valor mínimo de segurança e abaixo da altitude máxima de vôo da aeronave.

† O sistema deve oferecer ao usuário a opção de desenhar ou delimitar uma determinada

- região. O usuário poderá coletar waypoints com o auxílio de um receptor GPS e os inserir no desenho como marcos, delimitando a região desejada.

$\uparrow$ O usuário pode definir as tarefas a serem realizadas pela aeronave. Cada tarefa é associada a um waypoint e cada waypoint pode ter mais de uma tarefa associada a ele. As possíveis tarefas da aeronave do projeto ARARA são:

- Tirar fotografia - deverá ser especificado o número de fotografias a serem tiradas em um determinado waypoint e o intervalo de tempo entre elas;

- Filmar - deverá ser especificada a duração da filmagem;

- Finalizar missão.

† O usuário pode definir a precisão com que o waypoint deve ser alcançado.

O. sistema deve fornecer opção ao usuário para redefinir a rota e tarefas.

$\rightarrow$ O sistema deve formatar a rota e as tarefas gerando um plano de vôo. O plano de vộo deve ser carregado a bordo da aeronave no módulo Sistema de Navegação.

\subsubsection{Requisitos funcionais do módulo Sistema de Navegação}

† O Sistema de Navegação deve ser iniciado somente quando a aeronave já estiver voando e o piloto automático ativado.

† O sistema pode ser ativado e desativado por um sistema de rádio-controle. 
† O Sistema de Navegação deve ser ativado quando a aeronave atingir determinada velocidade e altitude. Os valores de velocidade e altitude dependem das características operacionais de cada aeronave.

$\downarrow$ O sistema deve ser desativado quando a aeronave atingir o waypoint final da rota. Antes de ser desativado, o sistema deve enviar ao piloto automático um comando para finalizar a missăo. O piloto automático deve desligar o motor e ativar o pára-quedas para a realização do pouso.

$\downarrow$ Após ser iniciado, o Sistema de Navegação deve obter a posição atual para calcular as manobras básicas necessárias para alcançar o primeiro waypoint da rota.

$\dashv$ O sistema deve controlar o escalonamento das manobras para o piloto automático.

† Durante o vôo, o sistema deve verificar, continuamente, a posição e a direção da aeronave. Para isso, devem ser realizadas leituras contínuas nos sensores de posição (GPS), direção (bússola) éáltitude (altímetro).

† Se um dos sensores de navegação falhar, o sistema deverá enviar ao piloto automático um comando para abortar a missão.

$\rightarrow$ Os dados dos sensores devem ser alimentados no Sistema de Navegação juntamente com uma indicação de falha de cada sensor.

$\rightarrow$ O sistema deve monitorar a posição da aeronave continuamente. Caso a aeronave saia da rota devido a rajadas de vento, uma manobra de correção deve ser calculada e enviada para o piloto automático para que a aeronave retome a rota inicial.

+ Se não for possível o alcance de um waypoint, devido a limitações operacionais da aeronave, o sistema deve fornecer um conjunto de manobras para que a aeronave realize uma(rota alternativa para alcançar o próximo waypoint da rota.

Quando o waypoint esperado for alcançado, deve ser realizada uma análise dos prérequisitos das tarefas a serem realizadas nesse waypoint. Se um dos pré-requisitos não for atendido, o sistema deve calcular um novo conjunto de manobras para atender os pré-requisitos da tarefa. 
† Se não for possível o cálculo de um novo conjunto de manobras para atender o prérequisito de uma tarefa, o sistema deve abortar a tarefa e dar continuidade às próximas tarefas.

+ Se o waypoint for alcançado com uma precisão menor que a precisão especificada pelo usuário no módulo Planejador de Missão, o sistema deve calcular um novo conjunto de manobras para tentar alcançar o waypoint com uma melhor precisão. Este processo deve ser realizado um número finito de vezes.

† O sistema de navegação deve controlar a ativação e desativação dos equipamentos necessários (filmadora ou câmera fotográfica) para a realização das tarefas.

$\rightarrow$ O sistema deve gravar um arquivo de informaçōes sobre todas as tarefas realizadas. As tarefas que forem abortadas devido ao não-cumprimento dos pré-requisitos também devem ser gravadas, informando o tipo de erro que provocou o cancelamento da tarefa.

† O sistema deve monitorar continuamente o nível de combustível necessário para a realização da missão.

† O sistema deve enviar um sinal de rádio, em caso de interrupção da missão, para que a aeronave possa ser localizada após o seu pouso.

\subsection{Diagrama de Blocos da Fase III}

O sistema da fase III do projeto ARARA requer uma configuração de hardware similar à configuração proposta por Ribeiro [RIB00] na implementação da fase II.

A figura 3.1 apresenta um diagrama de blocos que ilustra os instrumentos, sistemas e componentes de hardware montados dentro da aeronave para a implementação da fase III. Não é necessário nenhum equipamento auxiliar no solo pois a aeronave tem operação autônoma. 


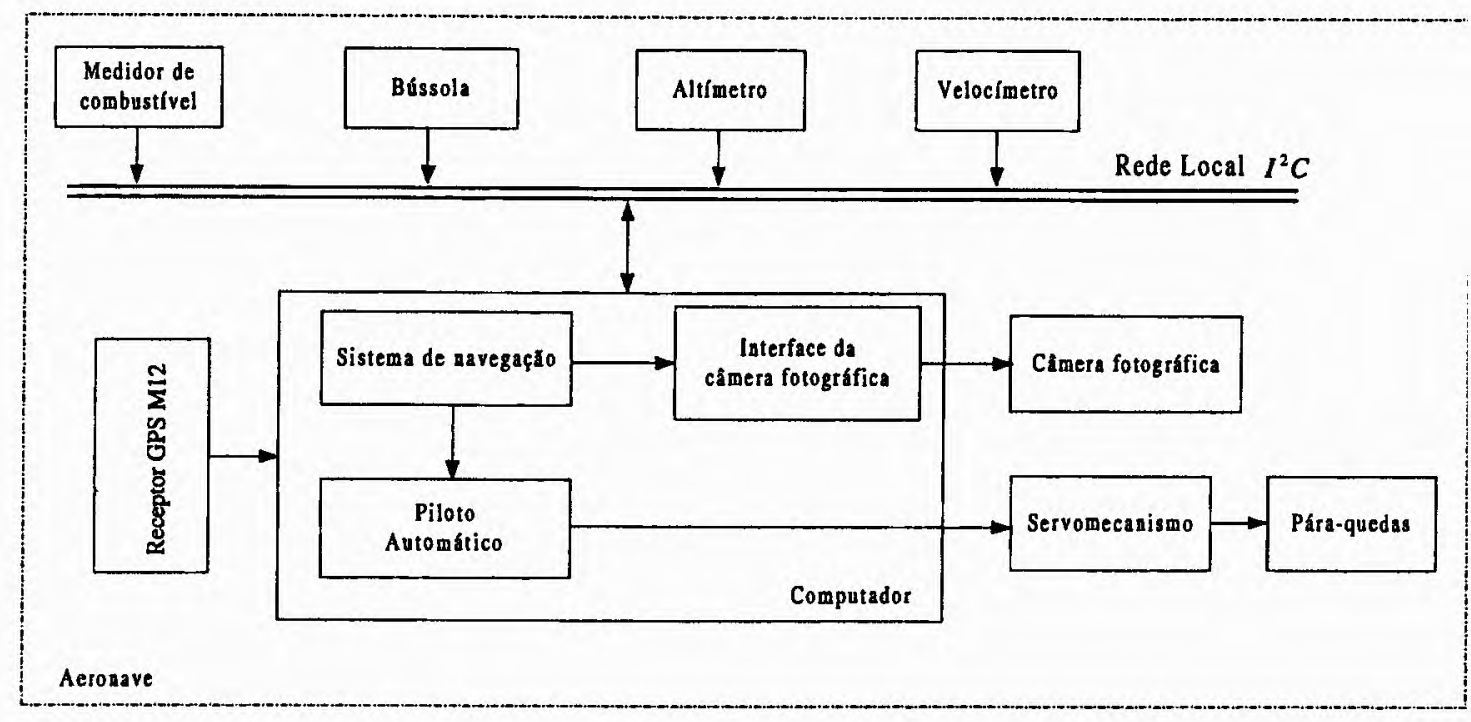

Figura 3.1 - Diagrama de blocos da fase III.

O protocolo de comunicação da rede $I^{2} C$ e os sensores altímetro, velocímetro e medidor de combustível serão desenvolvidos no laboratório LCAD (Laboratório de Computação de Alto Desempenho). O receptor GPS e a bússola serão adquiridos prontos.

A interface da câmera fotografica já foi implementada por Souza [SOU99] e o servomecanismo de controle do pára-quedas pelo Prof. Onofre Trindade Junior. Atualmente, o piloto automático está sendo desenvolvido por Neris [NERO0].

\subsubsection{Receptor GPS}

O receptor de GPS selecionado para a implementação da fase II é o M12 Oncore ${ }^{\mathrm{TM}}$ da Motorola. Este receptor foi escolhido por ser o menor receptor GPS da família Oncore. A tabela 3.1 mostra as principais características de um receptor M12.

Conforme mencionado na tabela 3.1, o padrão utilizado para formatar as mensagens é - NMEA 0183 (National Maritime Eletronics Association). Este padrão especifica um conjunto de sentenças onde cada sentença agrupa dados diferentes com tamanhos diferentes.' As sentenças do receptor M12 estão relacionadas na tabela $3.2^{10}$.

\footnotetext{
${ }^{10}$ Todas as siglas citadas na tabela podem ser encontradas no glossário.
} 
Tabela 3.1 - Características do receptor de GPS M12.

\begin{tabular}{|c|c|}
\hline Dimensōes & - $40 \times 60 \times 10 \mathrm{~mm}$ \\
\hline Peso & $\begin{array}{l}\text { - Receptor: } 25 \mathrm{~g} \\
\text { - Antena: }<40 \mathrm{~g}\end{array}$ \\
\hline Tensão de alimentação & - 2,75 a $3,2 \mathrm{Vdc}$ \\
\hline Datum & - WGS-84 \\
\hline Precisão & $\begin{array}{l}\text { - } 100 \mathrm{~m} \text { com SA } \\
\text { - menor que } 25 \mathrm{~m} \mathrm{sem} \mathrm{SA}\end{array}$ \\
\hline TTFF & $\begin{array}{l}\text { - < } 15 \mathrm{seg} \text { (Almanaque corrente, posição, hora e ephemeris) } \\
\text { - }<40 \mathrm{seg} \text { (Almanaque corrente, posição e hora) } \\
\text { - }<60 \mathrm{seg} \text { (nenhuma informação armazenada) }\end{array}$ \\
\hline Arquitetura do receptor & $\begin{array}{l}\text { 12 canais } \\
\text { - } \mathrm{L} 1-1575.42 \mathrm{MHz} \\
\text { Código CA }\end{array}$ \\
\hline Capacidade de rastreamento & - 12 satélites simultâneos \\
\hline Mensagens de saída & $\begin{array}{l}\text { - Latitude, longitude, altitude, velocidade, heading, tempo } \\
\text { - Interface NMEA } 0183 \text { a } 4800 \text { baud (GGA, GLL, GSA, GSV, RMC, VTG, ZDA) }\end{array}$ \\
\hline Condiçōes de funcionamento & $\begin{array}{l}\text { - Velocidade: } 515 \mathrm{~m} / \mathrm{s} \text { (1000 knots) } \\
\text { - }>515 \mathrm{~m} / \mathrm{s} \text { a altitudes }<18.000 \mathrm{~m}\end{array}$ \\
\hline
\end{tabular}

Tabela 3.2 - Sentenças do NMEA suportadas pelo receptor de GPS M12.

\begin{tabular}{|c|c|}
\hline Sentença: & Conteúdo da Sentença $=$ " \\
\hline GGA & Hora da fixação da posição, posição e dados \\
\hline GLL & Posição, hora da fixação da posição e status \\
\hline GSA & Modo de fixação da posição, $\mathrm{n}^{\mathbf{Q}}$ de satélites utilizados e DOP \\
\hline GSV & $\mathrm{N}^{2}$ de satélites visíveis, números PRN, elevação, azimuth e SNR \\
\hline RMC & $\begin{array}{l}\text { Hora UTC, status, latitude, longitude, Ground Speed, data e variação } \\
\text { magnética da posição fixada }\end{array}$ \\
\hline VTG & Porcentagem completada sobre a rota planejada e Ground Speed \\
\hline ZDA & Hora UTC, dia, mês, ano, offset da hora local, offset dos minutos local \\
\hline
\end{tabular}


Cada sentença NMEA inclui um ID que diferencia uma sentença da outra e um código Talker ID que identifica a origem dos dados. O padrão NMEA 0183 define 35 Talker IDs. Os principais IDs estão descritos na tabela 3.3.

Tabela 3.3 - Códigos Talker IDs

\begin{tabular}{|l|l|}
\hline Código & Especificação \\
\hline GP & GPS \\
\hline LG & Loran C/ GPS \\
\hline LC & Loran C \\
\hline II & Instrumentą̧̃o integrada \\
\hline
\end{tabular}

Os dados de uma sentença estão distribuídos em campos e estes são separados por vírgulas. Uma sentença inclui também um campo de checksum, separado por um asterisco, para validar a integridade dos dados. Toda sentença inicia com o caracter $\$$. O formato de uma sentença NMEA 0183 é:

$\$ \underbrace{G P}_{\text {Tal ker } \text { Dsen tencalD }}, \underbrace{2203200.0}_{\text {campol }}, \underbrace{26}_{\text {campo } 2}, \underbrace{06}_{\text {campo } 3}, \underbrace{1997}_{\text {campo4 }}, \underbrace{00}_{\text {campos }}, \underbrace{00}_{\text {campo }} * \underbrace{52}_{\text {chectsum }}$

Os formatos de todas as sentenças da tabela 3.2 estão detalhados no Apêndice A.

\subsection{Notação Utilizada nos Diagramas}

A notação utilizada na análise estruturada para a representação dos diagramas de fluxos de dados foi a de Yourdon [YOU92]. A tabela 3.4 mostra os símbolos utilizados nesta notação.

O módulo Sistema de Navegação por ser, além de um sistema de processamento de dados, um sistema reativo, é também representado em diagramas de estados. É utilizada uma extensão de diagramas de estados, os statechats [HAR87]. Statecharts são especialmente para representar sistemas reativos complexos como sistemas distribuídos de tempo real, protocolos de comunicação e unidades controle de digital.

As características dos statecharts, importantes neste trabalho, são as representações de concorrência e sincronização entre estados, cluster de estados em um super-estado e 
mecanismo de comunicação broadcast entre componentes concorrentes. A tabela 3.4 mostra os símbolos dos statecharts que foram utilizados neste trabalho.

Tabela 3.4 - Símbolos utilizados nos diagramas do sistema SiNaCoM.

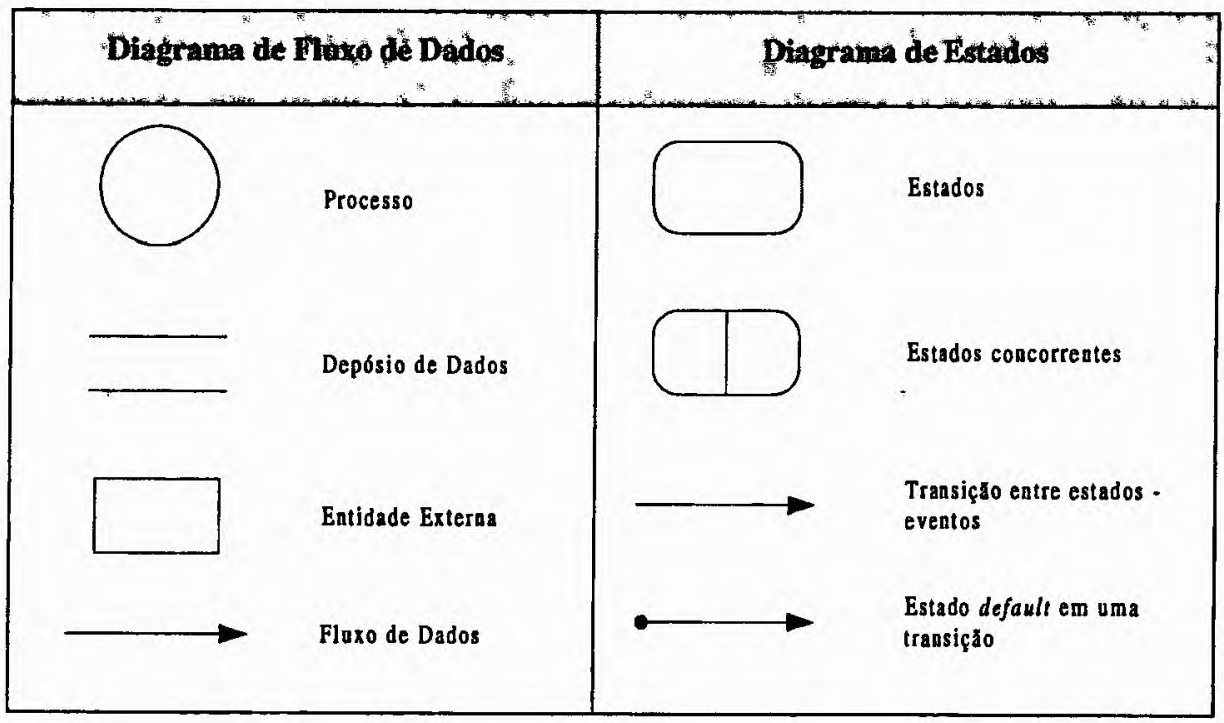

\subsection{Diagrama de Contexto}

O diagrama de contexto do sistema SiNaCoM é apresentado na figura 3.2. 


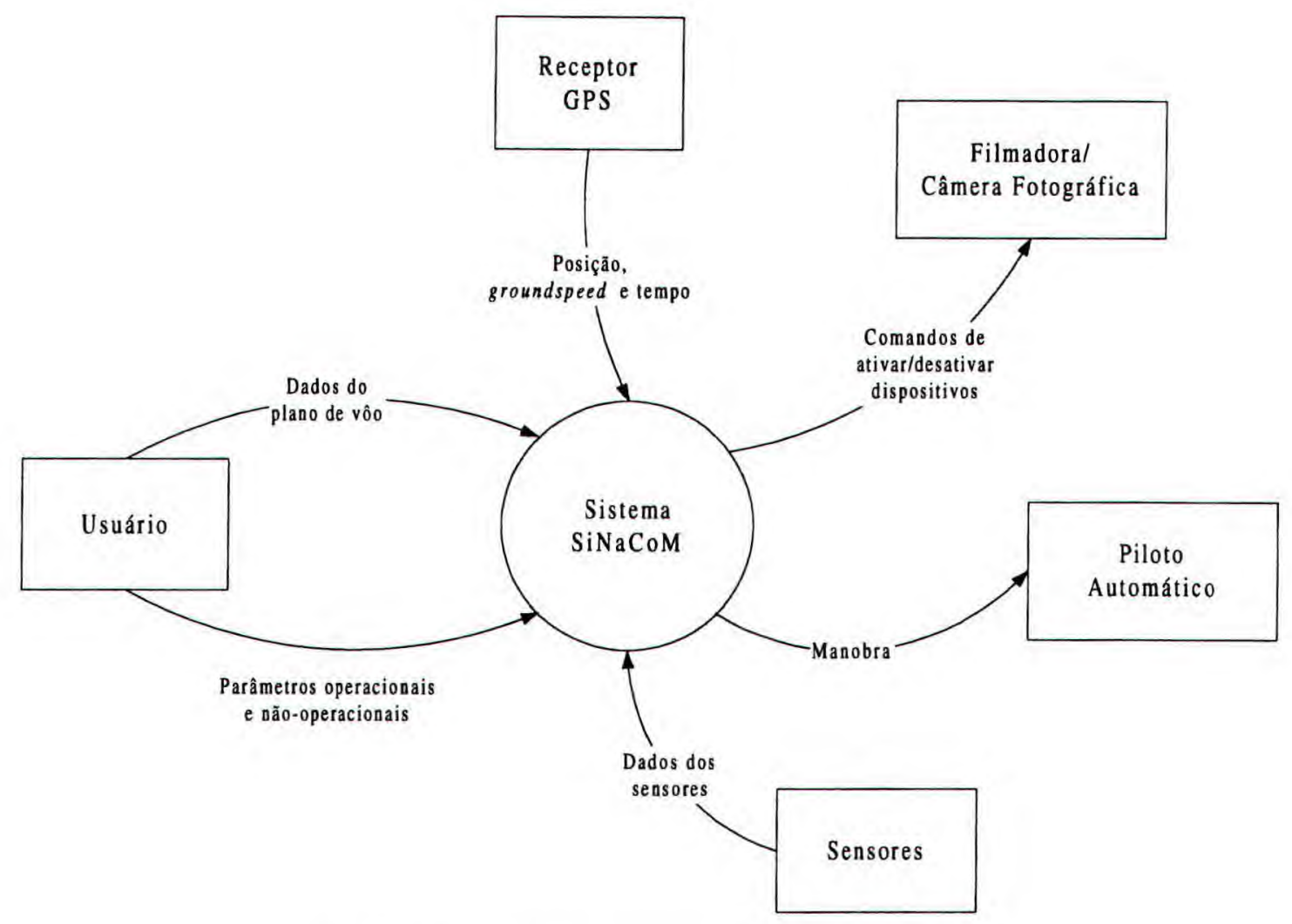

Figura 3.2 - Diagrama de contexto do sistema $\mathrm{SiNaCoM}$

A figura 3.3 mostra o diagrama de fluxo de dados de nível 1 do sistema $\mathrm{SiNaCoM}$. Neste diagrama são mostradas as duas principais funções do sistema, Planejar Missão e Controlar Navegação, que representam os módulos Planejador de Missão e Sistema de Navegação, respectivamente.

Nas seções a seguir, são apresentados os diagramas de nível 2 e 3 das funções citadas acima. Para efeito de clareza, os níveis das funções são apresentados em seções distintas. 


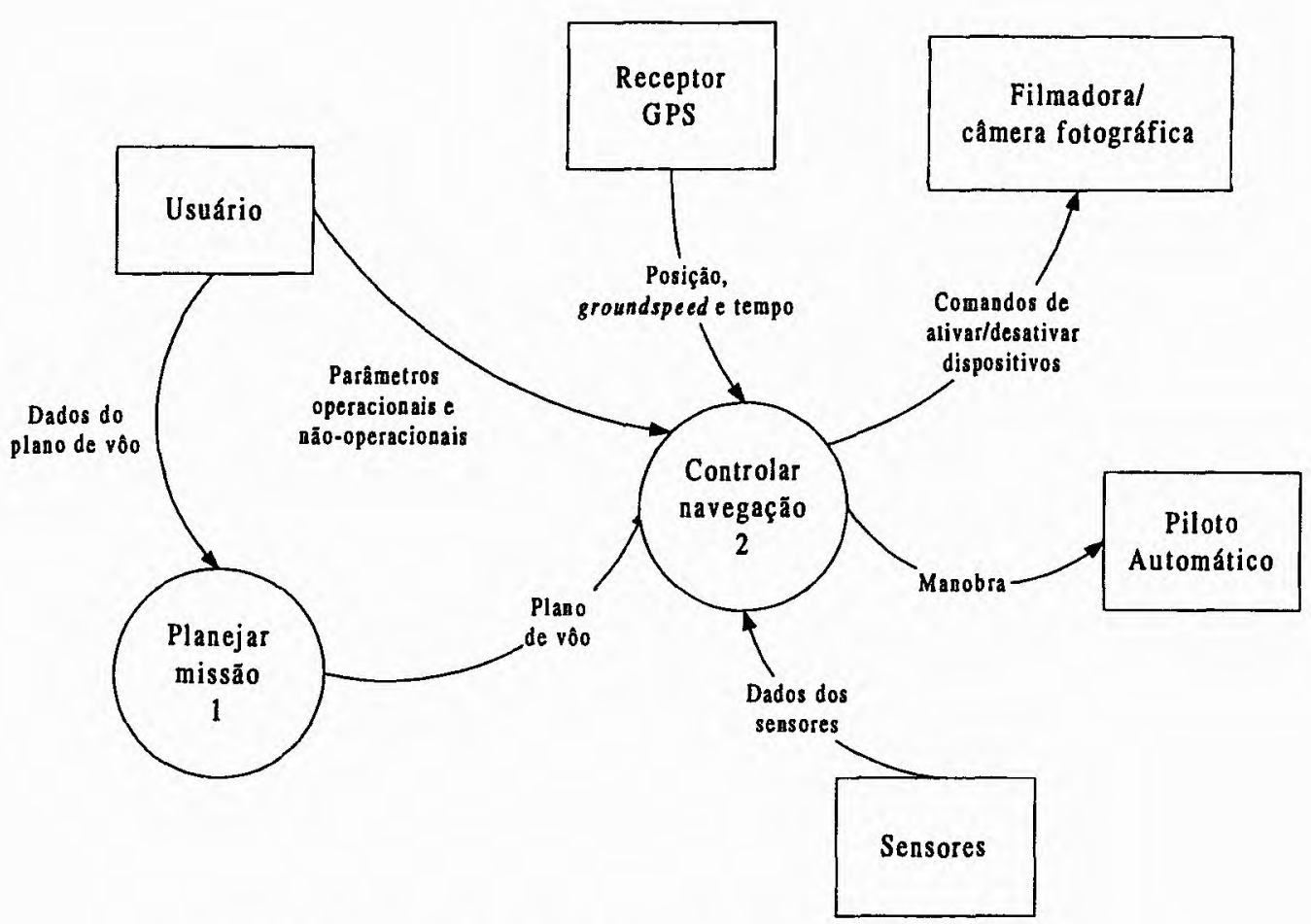

Figura 3.3 - Diagrama de fluxo de dados do sistema SiNaCoM-nível 1.

\subsection{Diagramas de Fluxo de Dados da Função Planejar Missão}

O diagrama de fluxo de dados, DFD, de nível 2 da função Planejar Missão é apresentado na figura 3.4 . 


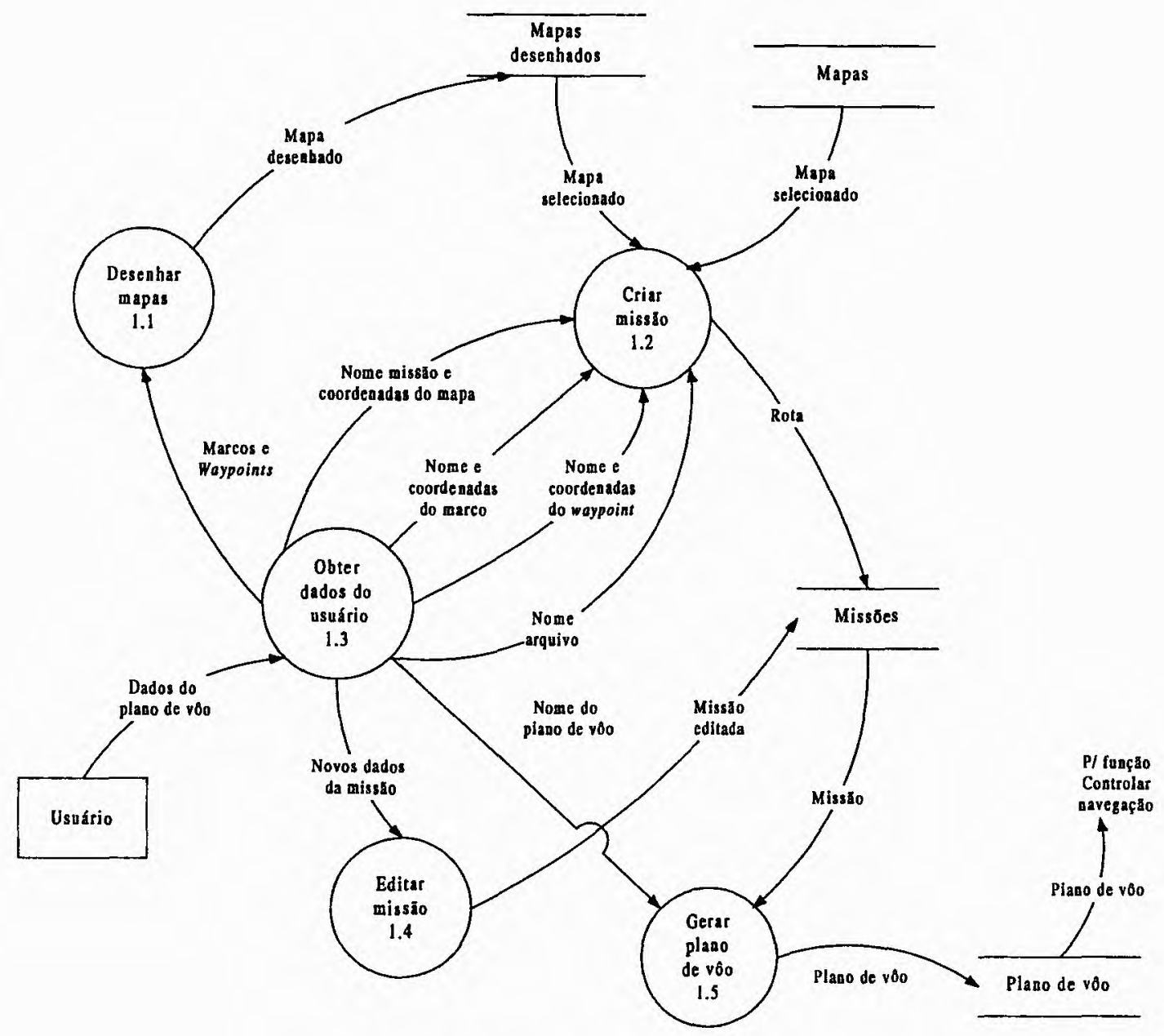

Figura 3.4 - DFD da função Planejar Missão - nível 2.

\subsubsection{Descrição das Funções}

As funções apresentadas no DFD da figura 3.4 são descritas nos itens a seguir.

\section{Desenhar Mapas}

Os contornos de uma determinada região são desenhados através desta função. $O$ usuário deve fornecer à função um conjunto de waypoints para delimitar essa região. Podem, ainda, ser inseridos marcos para indicar pontos como rios, prédios, rodovias, florestas, montanhas, etc. O mapa desenhado pelo usuário pode ser utilizado para criar missões. 


\section{Criar Missão}

Trata-se da função mais importante do módulo Planejador de Missão. Através desta função, o usuário traça a rota a ser seguida pela aeronave e define a lista de tarefas realizadas em cada waypoint da rota.

Para definir uma missão, pode-se utilizar um mapa pronto (bmp, jpeg ou gif) ou desenhá-lo. $O$ mapa é exibido na tela pela função Visualizar Mapa. Para essa visualização, o usuário entra com as coordenadas em latitude/longitude dos cantos superior esquerdo e inferior direito do mapa para que a função exiba o mapa corretamente na tela. Podem ser inseridos marcos no mapa selecionado para realçar pontos já conhecidos pelo usuário. Tais marcos devem ser identificados por nomes ou números. A figura 3.5 mostra o DFD da função Criar Missão.

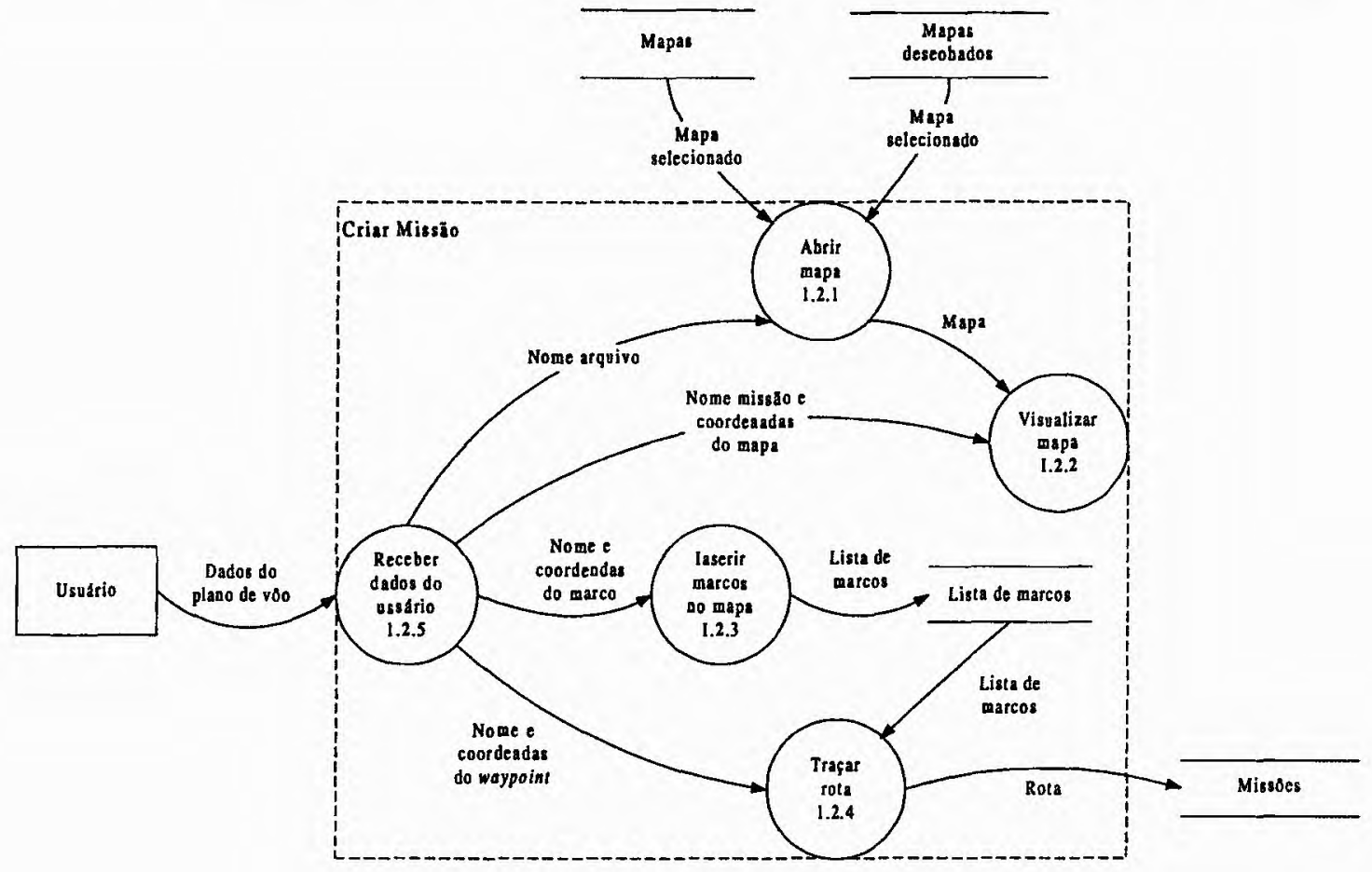

Figura 3.5 - DFD da função Criar Missão - nível 3.

Através da função Traçar Rota, pode-se definir a rota e as tarefas a serem realizadas pela aeronave. A rota é formada por waypoints, podendo também conter marcos. Além disso, é possível modificá-la a qualquer momento antes da geração do plano de vôo. Os waypoints e os marcos devem ser identificados por nomes ou números. Um waypoint pode ter ou não uma tarefa associada a ele. Um mesmo waypoint pode ter mais de uma tarefa. $\mathrm{O}$ usuário define as tarefas e os pré-requisitos associados a cada tarefa. 


\section{Editar Missão}

A missão, depois de planejada, pode ser aberta e modificada. As possíveis modificações podem ocorrer pela:

† Alteração do Nome da missão;

$\rightarrow$ Inserção de novos waypoints e marcos na rota com conseqüente definição de tarefas e pré-requisitos associadas a eles;

$\rightarrow$ Alteração de tarefas já associadas a um waypoint ou marco;

$\dashv$ Alteração dos pré-requisitos associados a tarefas já definidas;

+ Exclusão de waypoints ou marcos da rota.

\section{Gerar Plano de Vôo}

Essa função formata a missão selecionada pelo usuário gerando o plano de vôo que é enviado para o módulo Sistema de Navegação.

\subsection{Diagrama de Fluxo de Dados da Função Controlar Navegação}

O diagrama de fluxo de dados de nível 2 da função Controlar Navegação é ilustrado na figura 3.6. Para simplificar a visualização do DFD, as bases de dados Dados dos Sensores e Plano de Vôo foram duplicadas. 


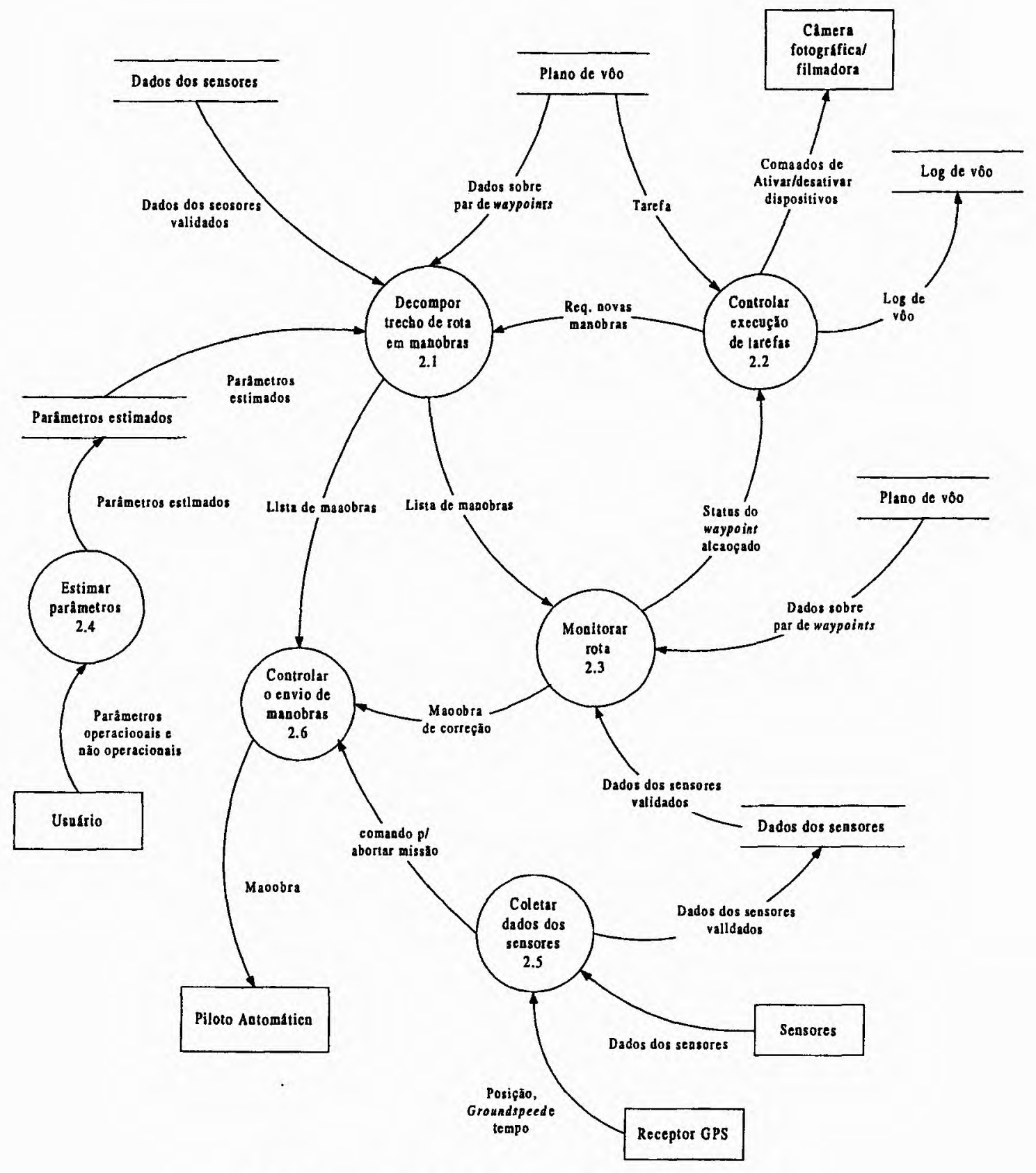

Figura 3.6 - DFD da função Controlar Navegação - nível 2.

\subsubsection{Descrição das funções}

As funções apresentadas no DFD da figura 3.6 são descritas a seguir. 


\section{Decompor Trecho de Rota em Manobras}

Esta função obtém de Plano de Vôo o próximo par de waypoints pertencente à rota e decompõe o trecho de rota compreendido entre eles em uma lista de manobras. Esta deve ser enviada às funções Controlar o Envio de Manobras e Monitorar Rota.

A figura 3.7 ilustra o DFD da função Decompor Trecho de Rota em Manobras.

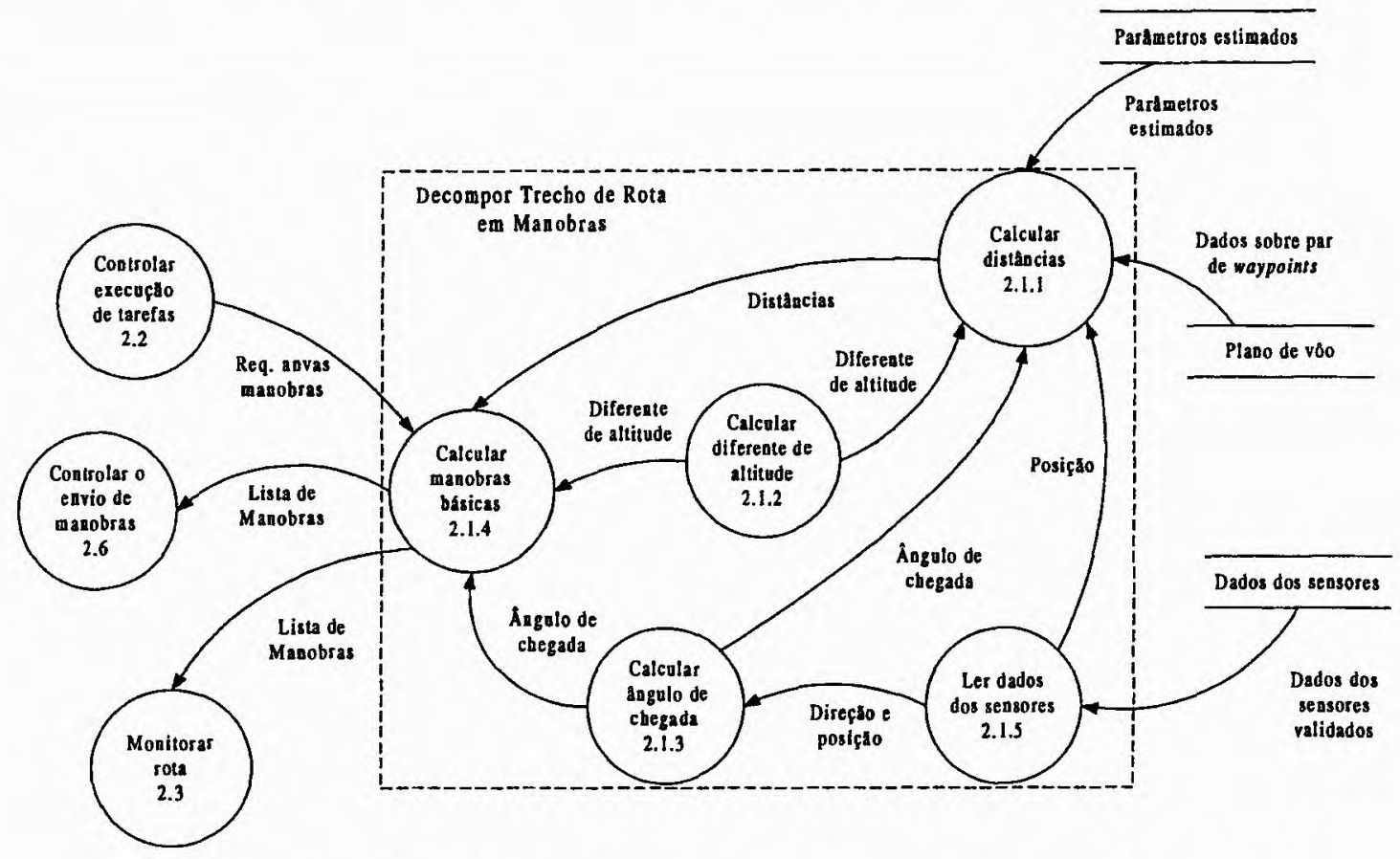

Figura 3.7 -DFD da função Decompor Trecho de Rota em Manobras - nível 3.

Existem algumas variáveis que são analisadas com a finalidade de identificar quais tipos de manobras devem ser calculadas e executadas pela aeronave para que esta possa voar do waypoint de origem até o waypoint de destino. Estas variáveis são:

$\rightarrow$ A diferença de altitude entre os waypoints;

† A distância entre os waypoints;

+ A distância necessária entre os waypoints para que uma manobra básica possa ser realizada;

$\dashv \mathrm{O}$ ângulo formado entre a proa da aeronave e a reta que liga os dois waypoints. 
Cada uma destas variáveis é calculada por uma função específica, conforme mostra o DFD da figura 3.7. A função Calcular Manobras Básicas recebe todos os valores das variáveis citadas acima e define uma lista de manobras.

Se um waypoint não for alcançado com a precisão desejada, a função Controlar Execução de Tarefas requisita o cálculo de novas manobras para tentar alcançá-lo com maior precisão.

\section{Controlar Execução de Tarefas}

A figura 3.8 ilustra o DFD desta função mais detalhadamente. A função Monitorar Rota informa à função Controlar Execução de Tarefas o alcance do waypoint de destino. Então as tarefas relacionadas a este waypoint são lidas da base de dados Plano de Vôo.

O waypoint onde a tarefa deve ser realizada possui uma precisão de posicionamento associada. Se a precisão desejada não é alcançada, a função Analisar Número de Tentativas solicita à função Decompor Trecho de Rota em Manobras o cálculo de novas manobras na tentativa de alcançar o mesmo waypoint com uma melhor precisão. Este processo pode se repetir um número finito de vezes. Se o número de tentativas é ultrapassado, a tarefa deve ser abortada.

A função Gravar Log de Vôo armazena o status de cada tarefa informando se houve sucesso ou não na realização da mesma. No caso de sucesso, o valor das coordenadas e altitude onde a tarefa foi realizada também deve ser armazenado.

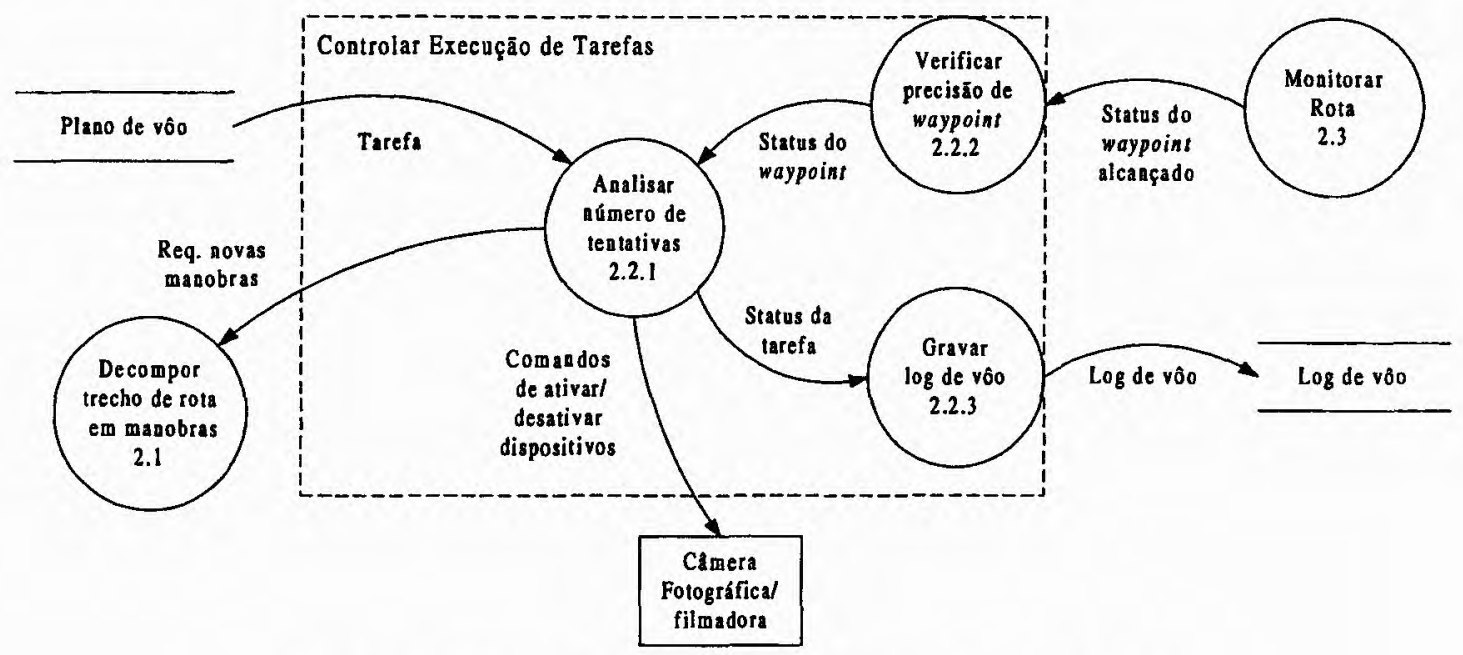

Figura 3.8 - DFD da função Controlar Execuçāo de Tarefas - nível 3. 


\section{Monitorar Rota}

A posição da aeronave deve ser monitorada continuamente com base na lista de manobras recebidas pela função Decompor Trecho de Rota em Manobras.

A função Monitorar Rota lê os dados dos sensores em Dados dos Sensores. A partir destes dados, a posição, a altitude e o heading atuais da aeronave são comparados com a posição, a altitude e o heading desejados. $O$ intervalo de tempo dentro do qual ocorre a comparação depende do tempo de atualização dessa base de dados. Quando a comparação resulta em um valor verdadeiro, uma nova manobra da lista de manobras é monitorada.

A figura 3.9 mostra esse processo em um nível mais detalhado. Caso a aeronave saia de sua rota pré-programada, a função Comparar Velocidades GS e AS identifica o desvio de rota através da comparação contínua das velocidades de solo (GS - Ground speed) e aerodinâmica (AS - Airspeed). A função Calcular Ângulo de Correção de Desvio é informada sobre o desvio e calcula o ângulo que, somado ao heading atual da aeronave, faz com que esta chegue ao destino mesmo voando fora da rota original. Após o cálculo do ângulo, uma manobra de correção, ou seja, o novo heading, é enviado para a função Controlar o Envio de Manobras.

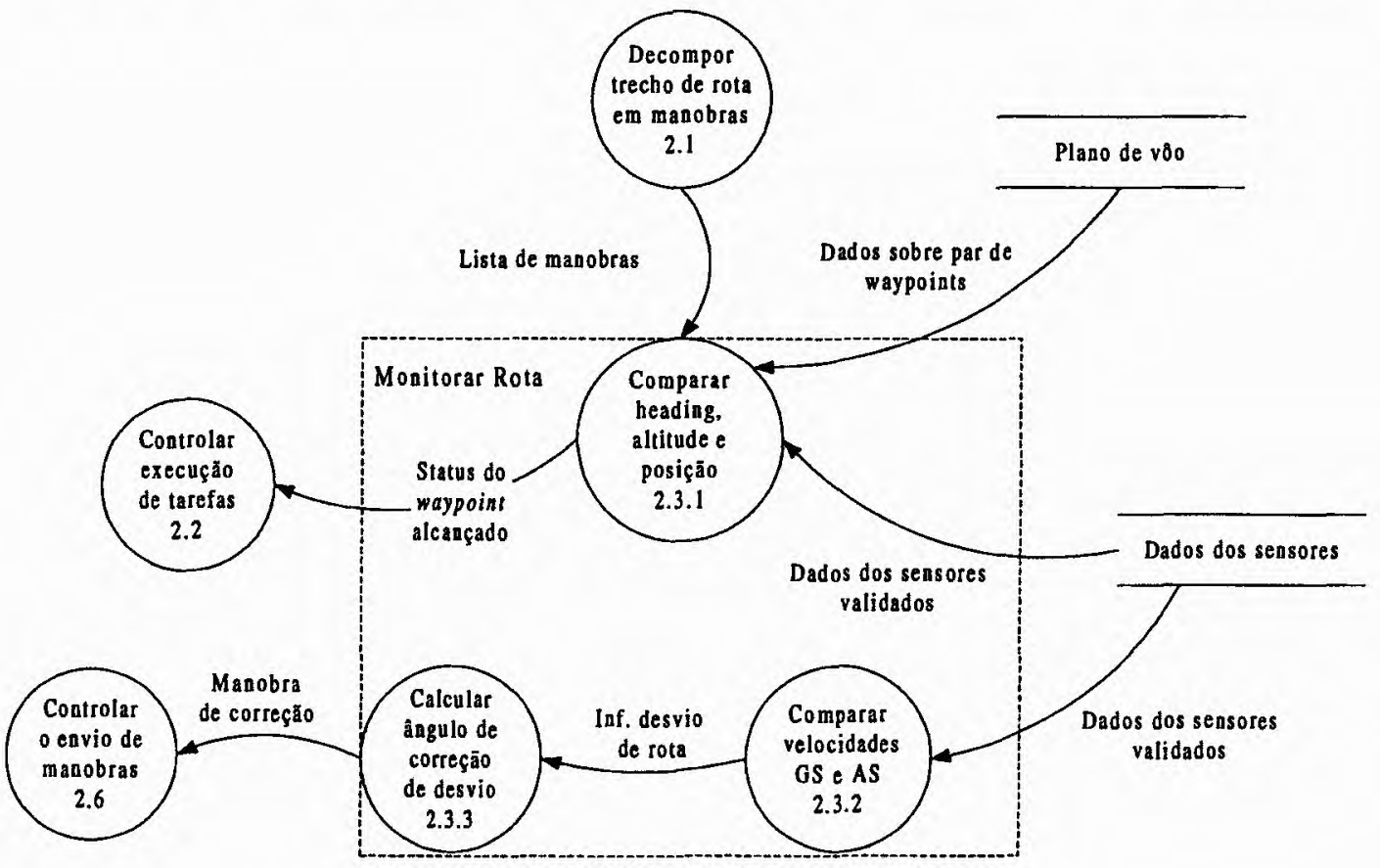

Figura 3.9 - DFD da função Monitorar Rota - nível 3. 
Quando o waypoint esperado for alcançado, a função Monitorar Rota informa à função Controlar Execução de Tarefas a posição atingida para que as tarefas sejam realizadas.

\section{Coletar Dados dos Sensores}

Os dados dos sensores devem ser coletados através da rede $I^{2} C$, validados e atualizados na base de dados Dados dos Sensores. Caso a rede esteja sem comunicação ou um dos sensores não responda, esta função comunica à função Informar Falha Sensor o não-recebimento dos dados. Os dados do receptor GPS não são lidos dessa rede, sendo obtidos diretamente da porta serial do computador central da aeronave.

Os dados que são lidos com sucesso são validados. A função Validar Dados dos Sensores verifica se o valor lido está dentro dos limites possíveis de valores para aquele sensor. Se o valor estiver incorreto, esta função envia uma mensagem de erro à função Informar Falha Sensor. Esta função, por sua vez, envia um comando de abortar missão para a função Controlar o Envio de Manobras.

O DFD da figura 3.10 ilustra as sub-funções da função Coletar Dados dos Sensores.

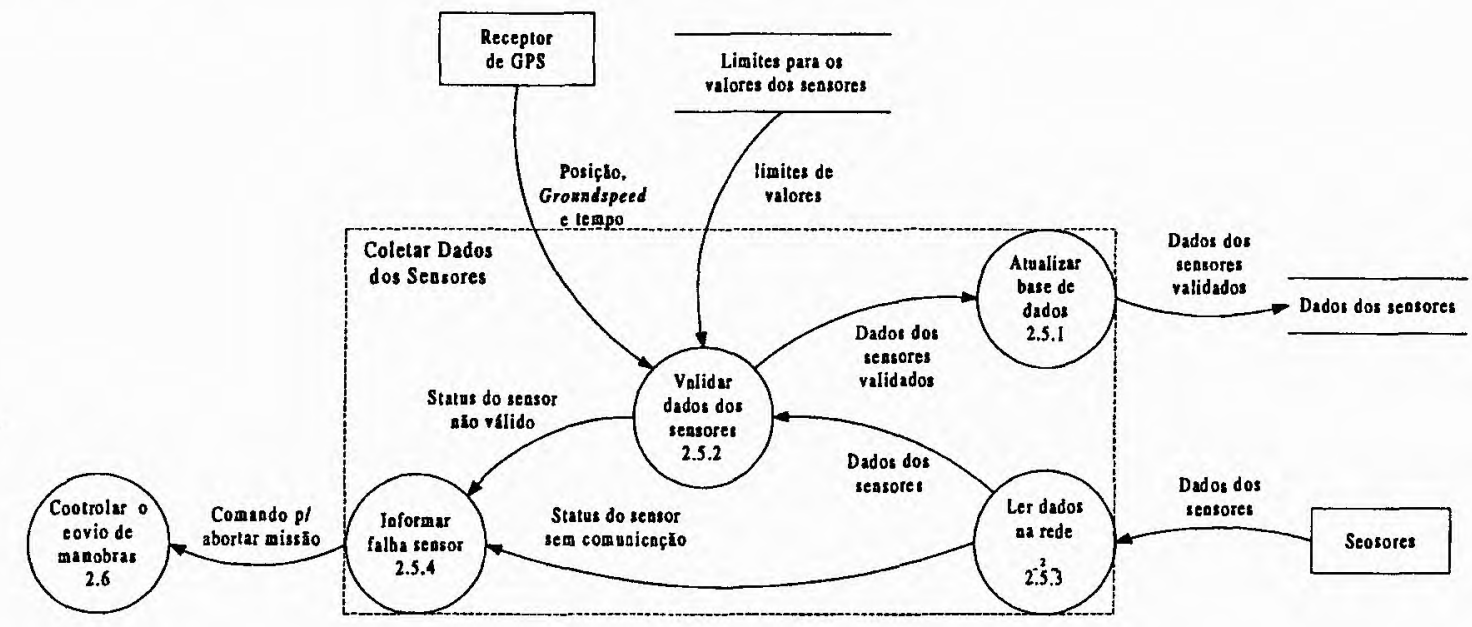

Figura 3.10 - DFD da função Coletar Dados dos Sensores - nível 3.

\section{Controlar o Envio de Manobras}

Esta função controla a emissão do conjunto de manobras para o Piloto Automático. A função Escalonar Manobras determina a ordem de envio das manobras, que são enviadas uma de cada vez pela função Enviar Manobras. O comando para abortar missão tem prioridade em relação aos outros comandos. 
A figura 3.11 mostra a função Controlar o Envio de Manobras.

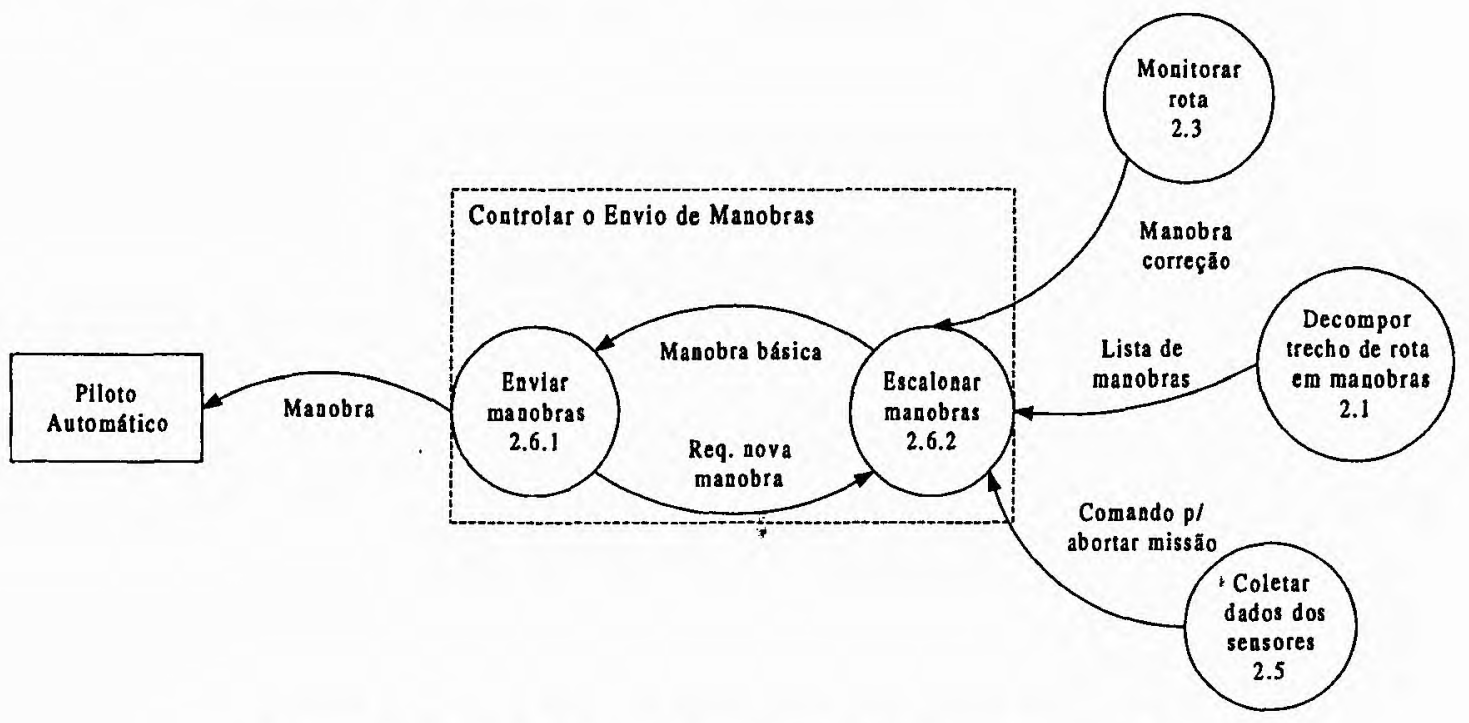

Figura 3.11 -DFD da função Controlar o Envio de manobras - nível 3.

\subsection{Diagramas de Estados do Módulo Sistema de Navegação}

Na figura 3.12 é mostrado o statechart que espelha o laço de controle básico do Sistema de Navegação. Quando o sistema é ativado via sinal de rádio, a posição atual da aeronave é lida na base de dados dos sensores. Os processos responsáveis por decompor o trecho de rota e enviar manobras são iniciados. As manobras são, então, calculadas para o trecho de rota compreendido entre o próximo par de waypoints e enviadas para o piloto automático por um processo concorrente ao processo que monitora a rota da aeronave.

A posição alcançada para a realização de tarefas deve ser analisada para verificar a precisão. Se a precisão não for atendida, é realizada uma verificação do número de tentativas que foi estipulado pelo usuário. Após esta verificação, pode-se calcular um novo conjunto de manobras para tentar uma melhor precisão ou abortar a tarefa. 


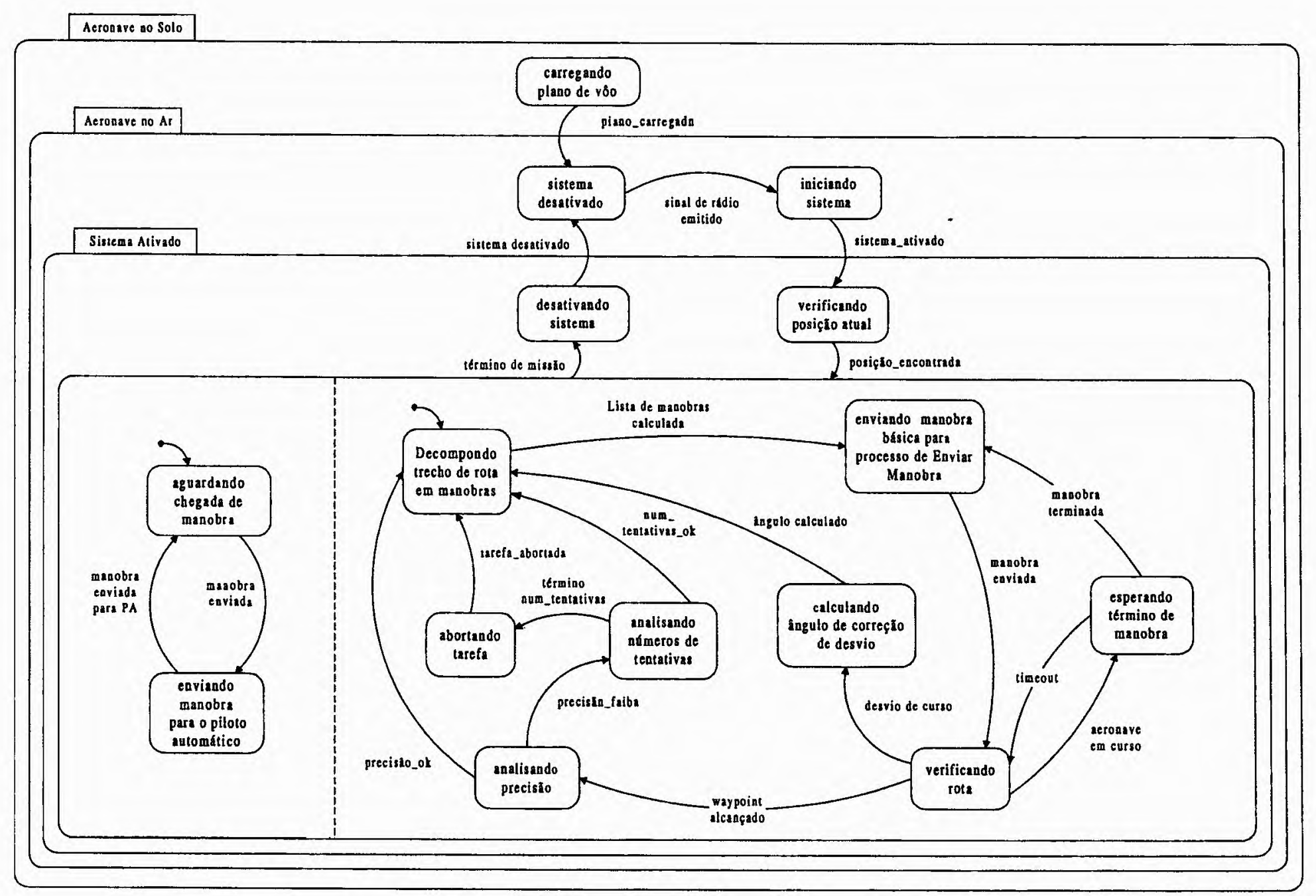

Figura 3.12 - Statechart do módulo Sistema de Navegaçāo 
Se o waypoint de destino for alcançado com a precisão desejada, é iniciado um novo processo para a realização de tarefas, conforme ilustra a figura 3.13. Este processo é concorrente ao processo de decomposição de rota.

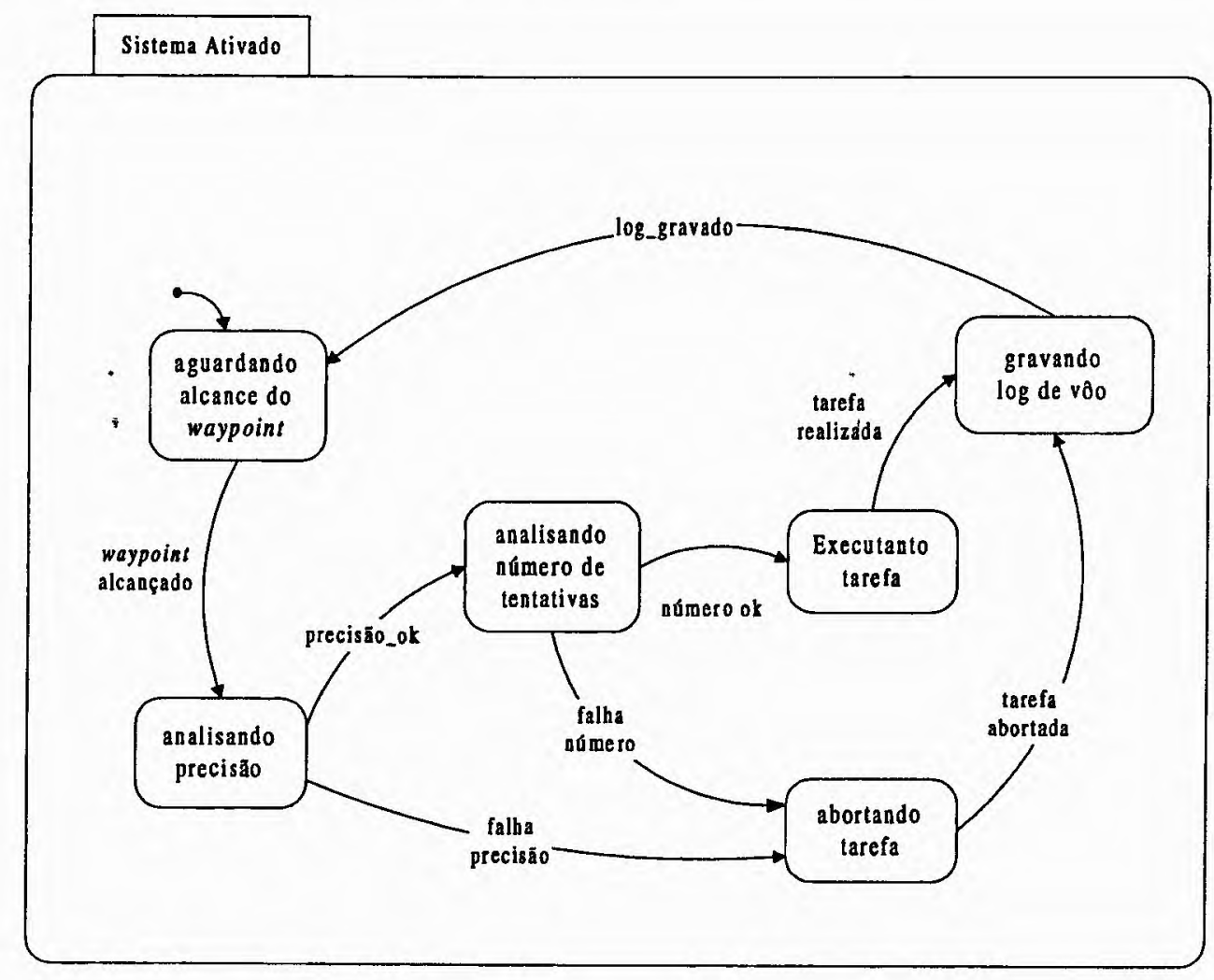

Figura 3.13 - Statechart do controle de execução de tarefas.

Quando o sistema de navegação é iniciado, são criados quatro processos para a leitura de dados dos sensores, um para cada sensor, conforme ilustra a figura 3.14. Os dados são lidos da rede interna da aeronave e analisados para verificar a existência de falhas nos sensores. Se não houver falhas, os dados sāo atualizados em uma tabela compartilhada pelos processos envolvidos no cálculo de manobras e no monitoramento de posição. 


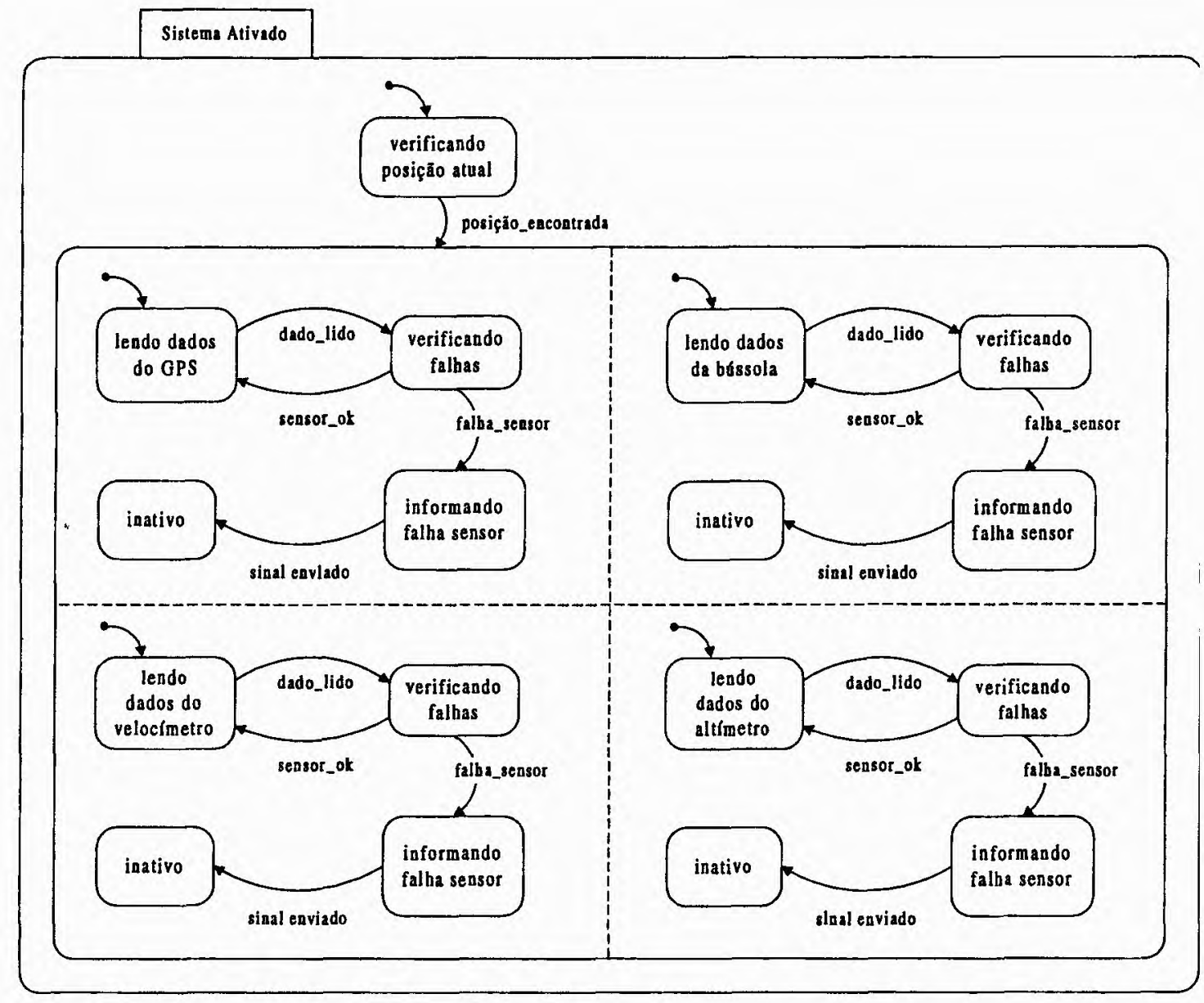

Figura 3.14 - Statechart da leitura de dados dos sensores.

\subsection{Considerações Finais}

Neste capítulo foi apresentado o receptor GPS selecionado para a implementação da fase III do projeto ARARA. Também foram apresentados os diagramas de fluxos de dados das funções mais relevantes do sistema $\mathrm{SiNaCoM}$. Foram descritas todas as funções dos módulos Planejador de Missão e Sistema de Navegação. O Sistema de Navegação, por ser um sistema de tempo real, também foi descrito em statecharts que definem os estados de um sistema.

No próximo capítulo é apresentada a implementação do módulo Planejador de Missão. São descritas a linguagem de programação e a base de dados utilizadas. A interface gráfica do sistema é apresentada, bem como suas telas principais. 


\section{Capítulo 4}

\section{Implementação do Módulo Planejador de Missão}

\subsection{Considerações Iniciais}

No capítulo anterior foram descritos a análise de requisitos, o projeto e a especificação dos módulos Planejador de Missão e Sistema de Navegação. Neste capítulo são apresentados os detalhes da implementação do módulo Planejador de Missão, baseados na análise realizada no capítulo anterior.

Na seção 4.2 são apresentados a linguagem de programação utilizada para o desenvolvimento do software, as justificativas da escolha desta linguagem e o componente de software utilizado para auxiliar no desenvolvimento. A seção 4.3 apresenta a base de dados utilizada no armazenamento da missão, as tabelas criadas e os seus campos. Na seção 4.4 são apresentadas as interfaces do sistema e uma discussão das principais funções. Na seção 4.5 , inserem-se as considerações finais deste capítulo.

\subsection{Implementação do Software}

O módulo Planejador de Missão é executado sobre o sistema operacional Windows 98. O sistema foi implementado na linguagem de programação Delphi 5. A escolha do Delphi é justificada pela facilidade de desenvolvimento de aplicações gráficas, pela grande disponibilidade de bibliotecas VCL (Visual Component Library), também chamadas de classes de componentes visuais [CAN00], e pelo fato do sistema da fase II do projeto ARARA ter sido desenvolvido em Delphi. 
A linguagem de programação Delphi facilita o desenvolvimento de programas pois não permite que ponteiros tenham acesso a áreas não autorizadas na memória, evitando erros do tipo segmentation fault [CAN00]. O Delphi 5 apresenta um ótimo ambiente para o paradigma de programação orientada a objetos.

Para acelerar o processo de implementação do sistema, foi utilizado um componente distribuído pela Global Majic Software [GOB01], o Moving Map. Este componente permite a visualização de mapas com coordenadas conhecidas. Esta visualização pode ser definida em qualquer unidade consistente (latitude/longitude, UTM, etc). Os mapas podem ser agrupados para formar um único mapa. Este componente permite também a inserção de waypoints e objetos, em qualquer ponto do mapa, na forma de objetos padronizados disponíveis no componente (avião, aeroporto, waypoint, landmark, etc), objetos desenhados pelo usuário ou de figuras com extensão bmp ou gif.

O objeto Moving Map possui duas estruturas do tipo lista para armazenar dados sobre os waypoints e marcos ${ }^{11}$ que são inseridos no mapa. A lista de waypoints e a lista de marcos são ordenadas pelo ID do waypoint e pelo ID do marco, respectivamente. Os dados armazenados em cada nó de uma lista são as propriedades relacionadas nos objetos da figura 4.1.

Algumas propriedades do objeto waypoint foram configuradas como constantes para diferenciar dos marcos que podem assumir quaisquer formas e tamanhos. Estas propriedades são a forma, o tamanho, a cor e o estilo do waypoint. Outras propriedades que diferenciam um marco de um waypoint são o WaypointLineColor e o WaypointLineStyle que são as linhas que ligam um waypoint ao outro na rota. Quando um marco é inserido na rota, o nó da lista referente a este marco é copiado para a lista de waypoints.

\footnotetext{
${ }^{11}$ A lista de marcos no componente Moving Map é chamada de lista de objetos. O nome da lista foi mudado para ser compatível às especificações do sistema.
} 


\begin{tabular}{|l|}
\hline \multicolumn{1}{c|}{$\begin{array}{c}\text { Objeto: } \\
\text { Waypoint }\end{array}$} \\
\hline Waypoints \\
WaypointID \\
WaypointCaption \\
WaypointColor \\
WaypointScale \\
WaypointStyle \\
WaypointSymbol \\
WaypointX \\
WaypointY \\
WaypointZ \\
WaypointLlneColor \\
WaypointLineStyle \\
\hline DelMapWaypoint \\
CreateRoute
\end{tabular}

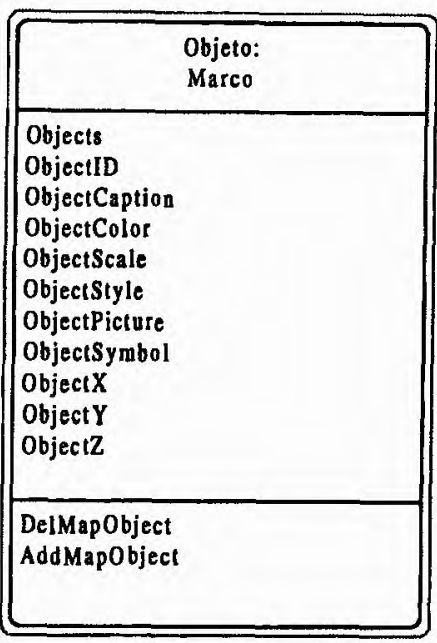

Figura 4.1 - Objetos do componente Moving Map.

\subsection{Base de Dados}

O Delphi possui duas bases de dados nativas, o Paradox e o dBASE. Para armazenar os dados do módulo Planejador de Missão, foi utilizada a base de dados Paradox 7 por permitir a inclusão de imagens em suas tabelas.

O Delphi não possui acesso direto as bases de dados, sendo necessário fazer uma interface com um gerenciador de dados, o Borland Database Engine (BDE). O BDE utiliza um driver específico para cada tipo de base de dados. Todas as versões do Delphi possuem um driver Standard para ser utilizado com o Paradox e o dBASE.

Foram criadas três tabelas para armazenar os dados da missão planejada pelo usuário:

Tabela Mapas: armazena todos os dados referentes ao mapa selecionado pelo usuário, são eles:

- O nome da missão;

- O limite superior e o limite inferior do mapa;

- A figura do mapa;

- A chave que relaciona o mapa aos waypoints e marcos.

Tabela Objetos: armazena os dados de todos os marcos inseridos no mapa. Ela possui um campo chave que a relaciona com a Tabela Mapas. Os dados sobre cada marco 
são:

- ID que identifica unicamente cada marco;

- Nome do marco;

- Posição tridimensional do marco em latitude, longitude e altitude;

- Número que identifica o tipo de desenho do marco. $O$ desenho pode ser padrão do componente Moving Map ou uma figura qualquer;

- Desenho do marco se o desenho não for um desenho padrão.

Tabela Waypoints: armazena dados sobre os waypoints que fazem parte da rota. Se um marco é escolhido pelo usuário para integrar a rota, os seus dados são copiados para a tabela de waypoints. Os dados sobre os waypoints são:

- ID que identifica unicamente cada waypoint;

- Nome do waypoint;

- Posição tridimensional do waypoint em latitude, longitude e altitude;

- Flag que indica se a tarefa Filmar foi selecionada ou não. Se esta tarefa for selecionada, outros campos devem ser preenchidos como a duração da filmagem e a precisão do ponto a ser filmado;

- Flag que indica se a tarefa Fotografar foi selecionada ou não. Se esta tarefa for selecionada, outros campos devem ser preenchidos como o número de fotos, o intervalo em que as fotos devem ser tiradas e a precisão do ponto a ser fotografado;

- Flag que indica se a tarefa Finalizar Missão foi selecionada ou não. Se esta missão for selecionada, o campo de precisão do ponto para finalização da missão deve ser preenchido.

\subsection{Interface do Sistema}

Nesta seção são mostradas as telas da interface do módulo Planejador de Missão. Na figura 4.2, é mostrada a tela principal para traçar um plano de vôo de acordo com alguns dos requisitos funcionais apresentados na seção 3.2.1. A partir desta interface, o usuário tem a opção de inserir marcos no mapa, traçar a rota ou gerar um novo plano de vôo. As principais funções implementadas no sistema estão contidas na barra de ferramentas. 


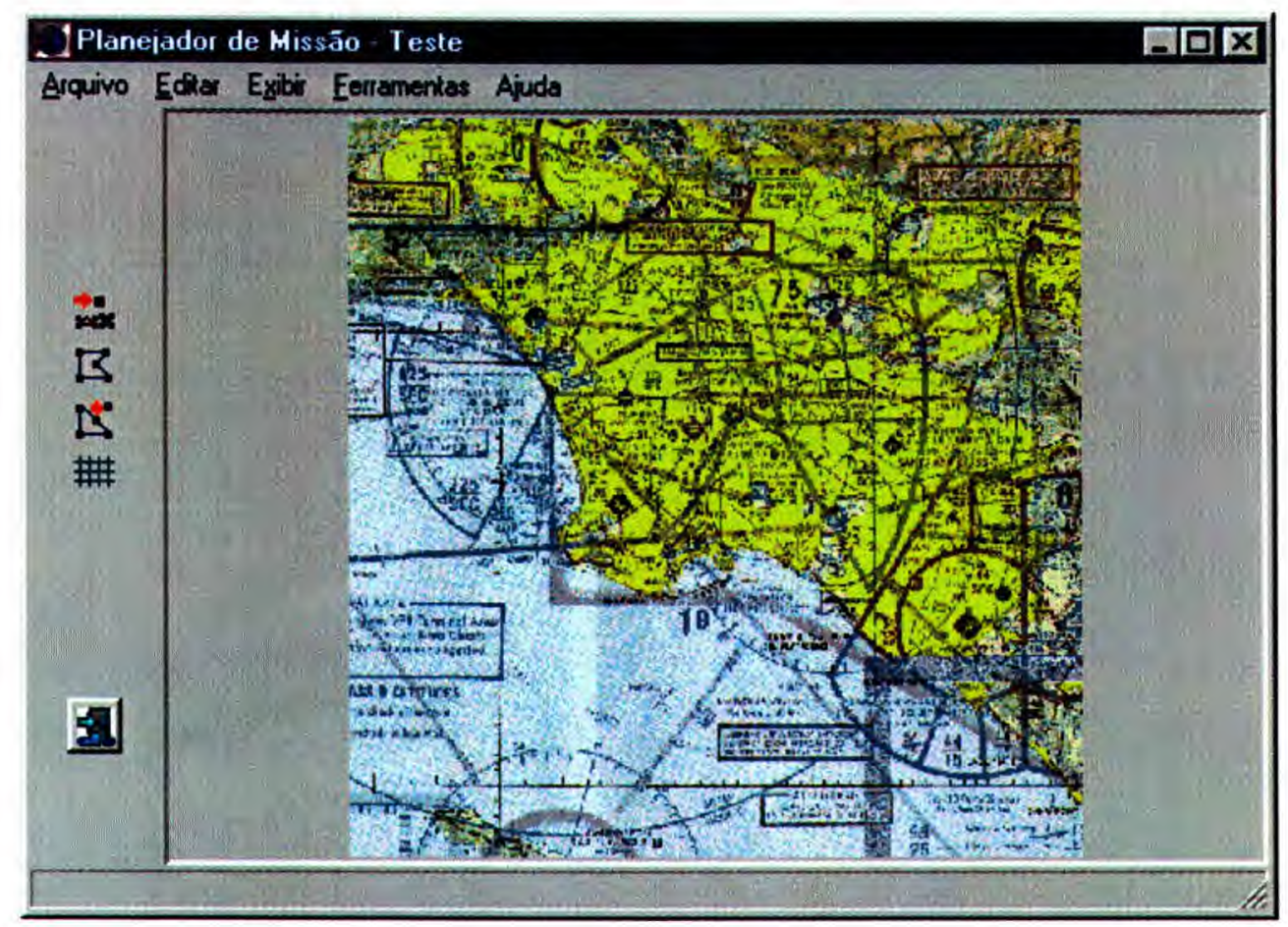

Figura 4.2 - Tela principal para traçar plano de vôo.

$\mathrm{Na}$ figura 4.3, é mostrada a tela de seleção do mapa e os campos de entrada de seus limites. Os limites do mapa devem ser devidamente preenchidos, caso contrário, o botão confirmar não é habilitado. Os valores dos limites devem estar dentro de uma faixa de valores permitida, de $0^{\circ}$ a $90^{\circ}$ para latitude e de $0^{\circ}$ a $180^{\circ}$ para longitude. $O$ formato do mapa utilizado para planejar a missão pode ser bmp, gif ou jpeg.

A figura 4.4 mostra a tela para a inserção de marcos no mapa. Todos os campos devem ser preenchidos corretamente, caso contrário, o botão confirmar não é habilitado e uma mensagem que identifica o tipo de erro é exibida na tela. Um marco pode ser inserido clicando no mapa ou através da inserção das suas coordenadas. No primeiro caso, os campos das coordenadas do ponto clicado são automaticamente preenchidos. No segundo caso, os campos devem ser preenchidos pelo usuário. Se os campos preenchidos estivem fora dos limites do mapa, uma mensagem de erro é exibida mostrando o valor máximo permitido. 


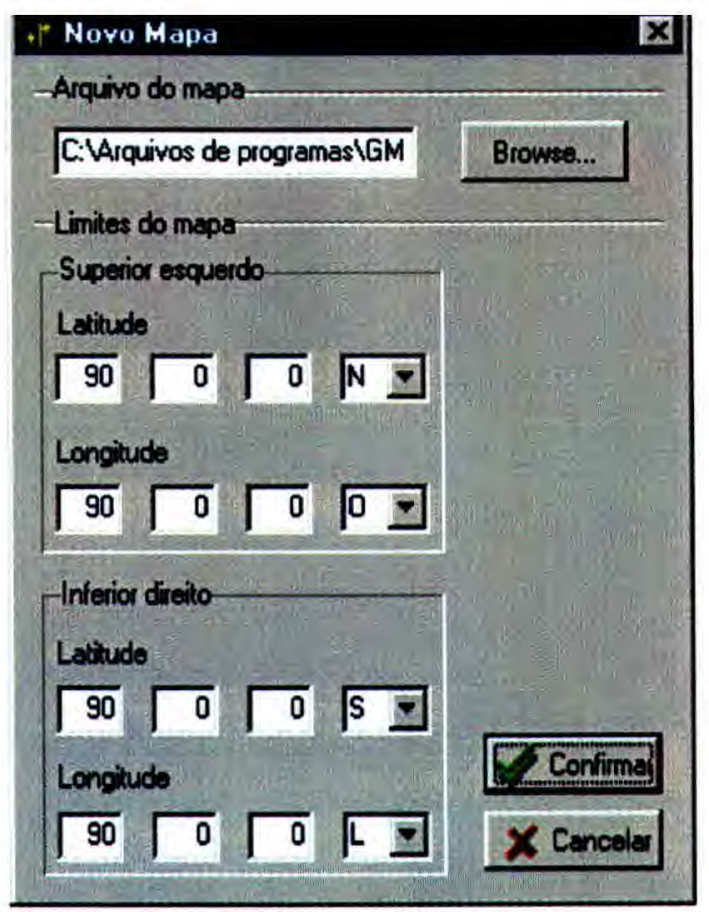

Figura 4.3 - Tela de entrada do mapa.

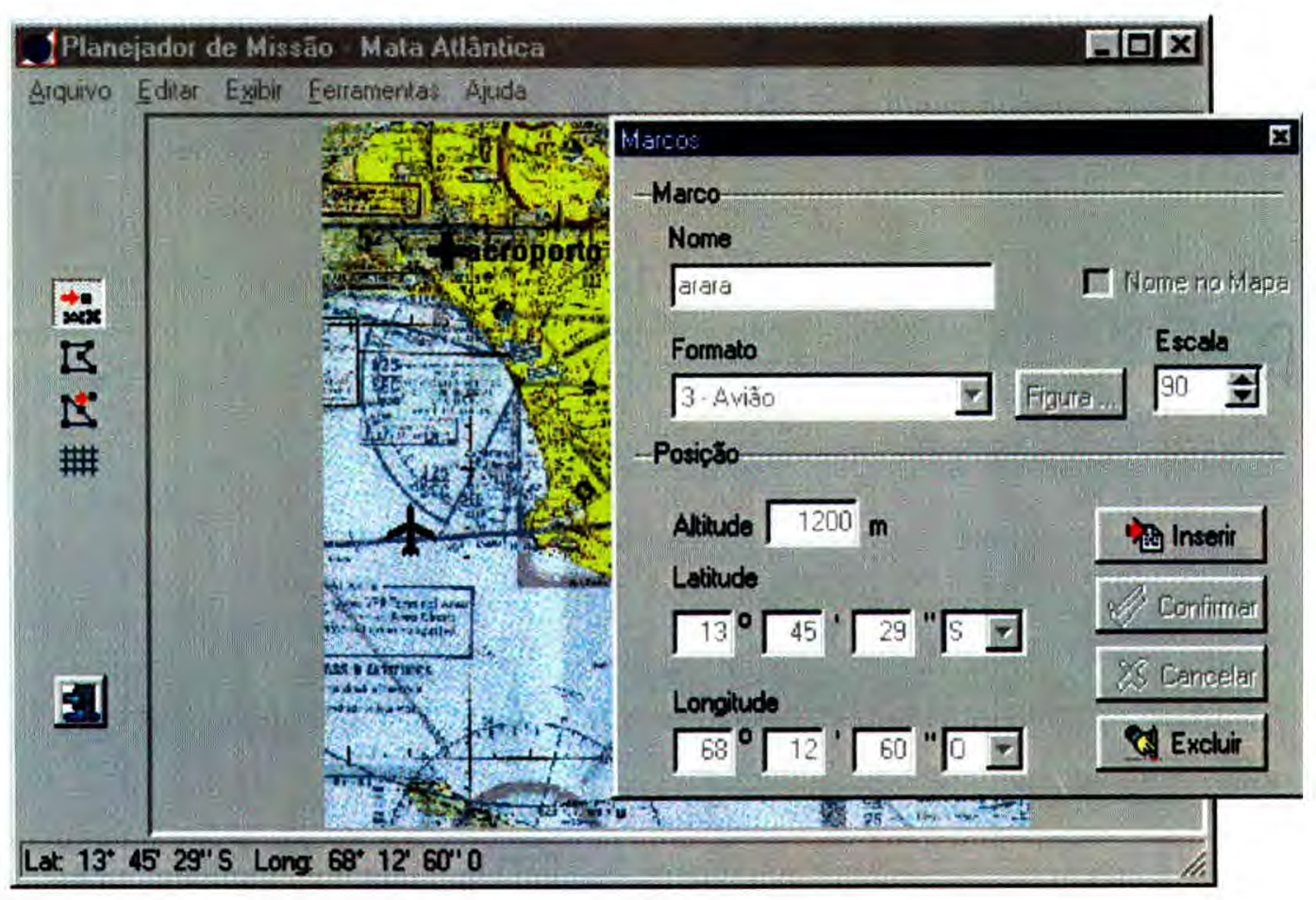

Figura 4.4 - Tela de inserção de marcos no mapa. 
A figura 4.5 mostra a tela de exclusão de um marco do mapa. A exclusão é feita através da seleção do marco desejado da lista de marcos do mapa.

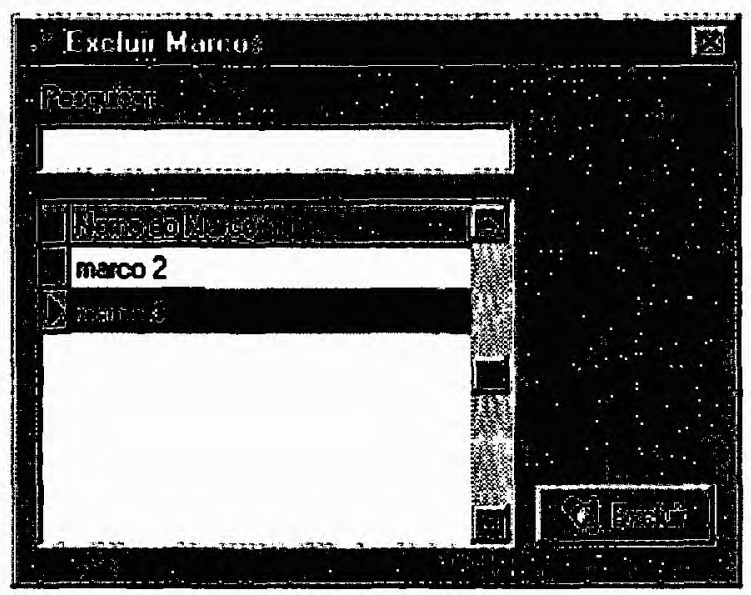

Figura 4.5 - Tela de exclusão de marcos do mapa.

A figura 4.6 mostra a interface de inserção de waypoints na rota. Os waypoints podem ser inseridos clicando no mapa ou através da digitação das suas coordenadas. $O$ botão confirmar somente é habilitado quando os campos nome, altitude, latitude e longitude estiverem corretamente preenchidos. A partir desta mesma interface, marcos que já foram inseridos no mapa podem ser inseridos na rota. A figura 4.7 mostra a tela para selecionar um marco a ser inserido na rota. 


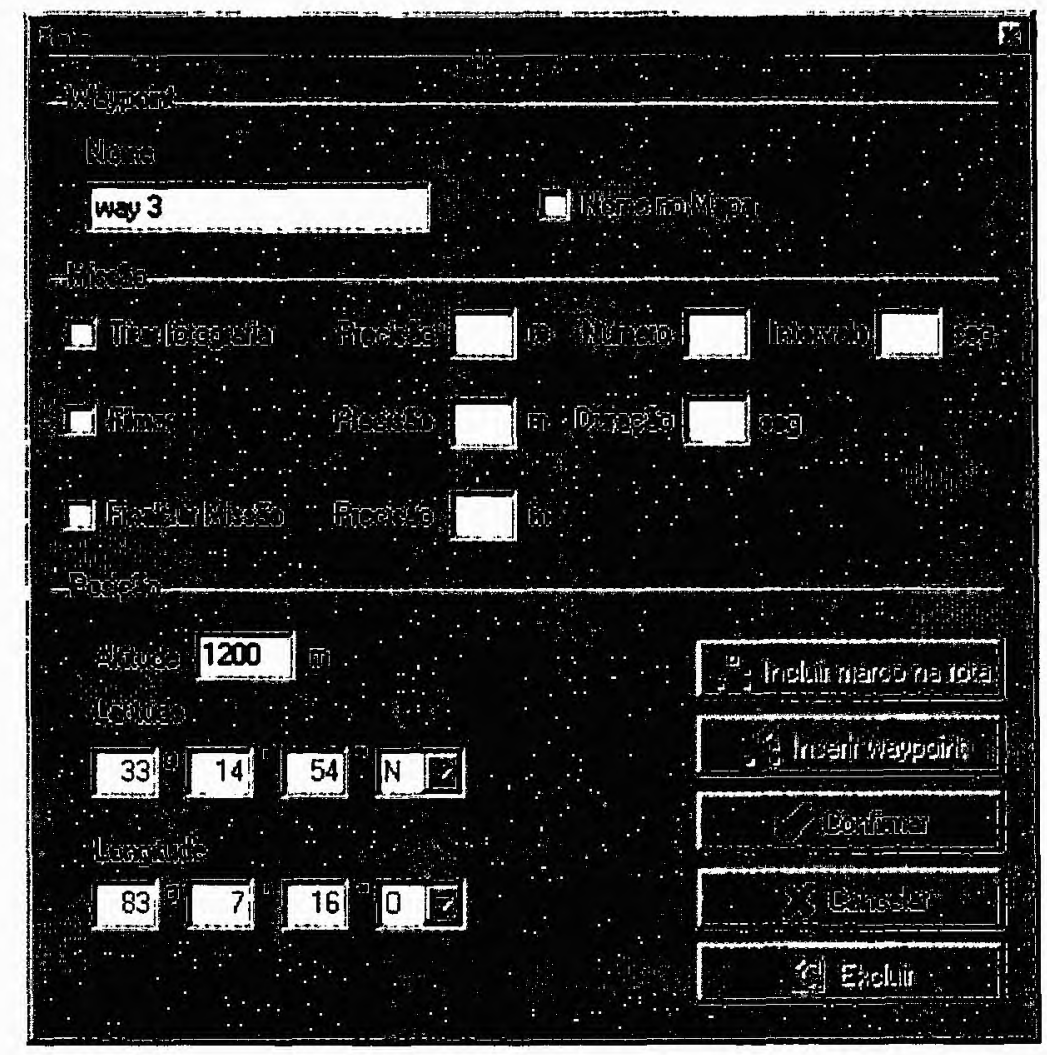

Figura 4.6 - Tela de inserção de waypoints na rota.

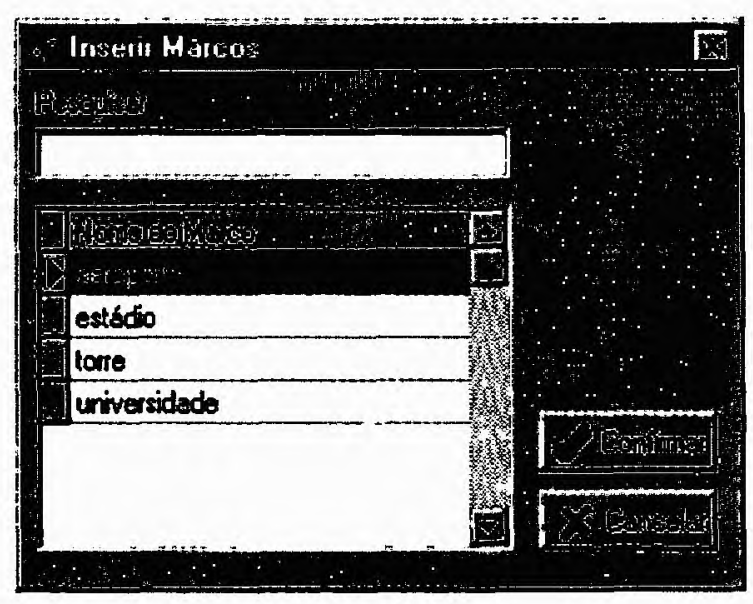

Figura 4.7 - Tela de inserção de marcos na rota.

A exclusão de waypoints da rota é realizada através da seleção do waypoint desejado na lista de waypoints, conforme ilustra a figura 4.8 . 


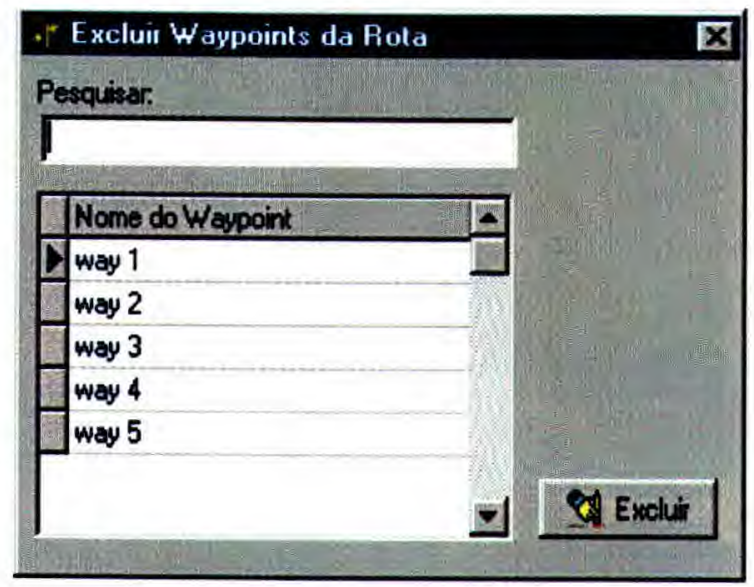

Figura 4.8 - Tela de exclusão de waypoints da rota.

As missões que já foram planejadas podem ser abertas e modificadas. A figura 4.9 mostra a tela de abertura de missão.

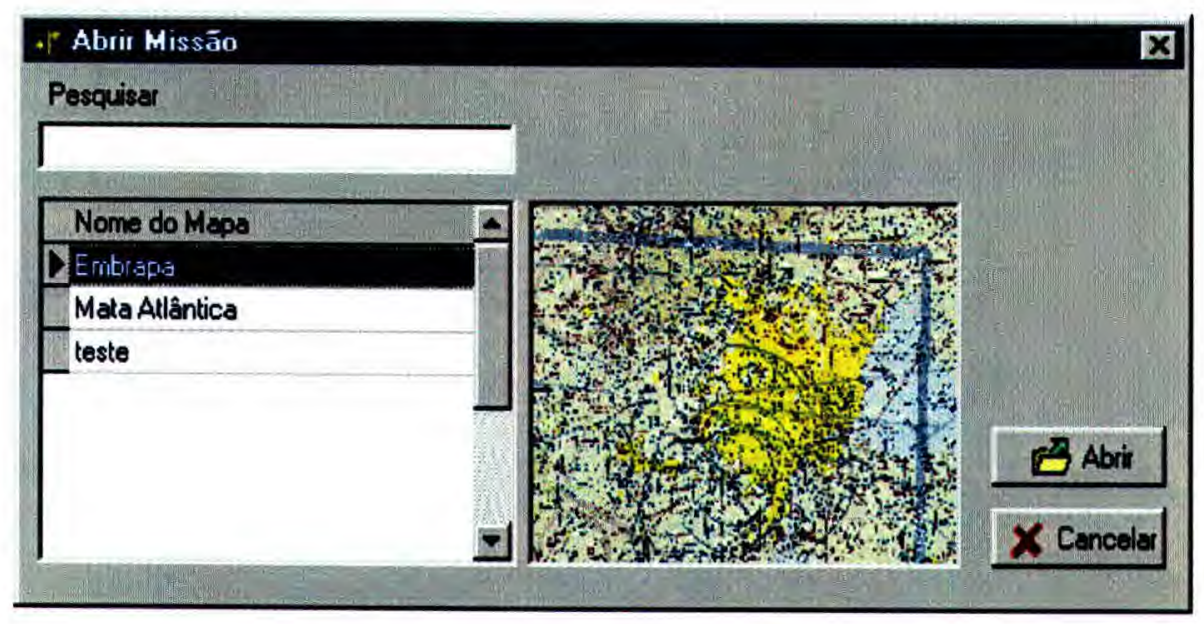

Figura 4.9 - Tela para abrir uma missão pronta.

A seguir é mostrado o arquivo texto gerado a partir de um plano de vôo, ou seja, a partir de uma tabela que contém todas as informações sobre os waypoints, as tarefas e prérequisitos. Este arquivo é interpretado pelo sistema de navegação de acordo com os campos da tabela Paradox gerada no Delphi. 
0:58:6:37:82:33:33:100:T:0:0:0:0:50:0:0:T:T:N:O

1:10:16:32:76:10:52:500:T:0:0:0:0:50:0:0:F:T:N:O

2:29:24:34:69:48:11:200:T:0:0:0:0:50:0:0:F:T:S:O

3:68:44:25:68:1:53:700:T:0:0:0:0:50:0:0:T:T:S:O

4:16:17:57:32:14:39:120:T:0:0:0:0:50:0:0:T:T:S:O

5:59:31:39:10:16:32:123:T:0:0:0:0:50:0:0:T:F:S:O

\subsection{Considerações Finais}

A implementação do módulo planejador de Missão foi apresentada neste capítulo. Foi justificada a escolha da linguagem de programação e da base de dados utilizada para armazenar dados da missão. Também foram apresentadas todas as telas da interface gráfica deste módulo.

No próximo capítulo é descrita a solução encontrada para o sistema de navegação. 


\section{Capítulo 5}

\section{Implementação do Módulo Sistema de Navegação}

\subsection{Considerações Iniciais}

Neste capítulo são apresentadas as soluçōes encontradas para um sistema de navegação, baseado em um receptor GPS, para uma aeronave do projeto ARARA.

Os parâmetros operacionais e não operacionais e o método de suas estimativas da aeronave do projeto ARARA são apresentados na seção 5.2. Todas as manobras básicas que serão realizadas pela aeronave e suas classificações estão descritas na seção 5.3.

O Sistema de Navegação calcula e analisa um conjunto de variáveis para a definição do conjunto de manobras a ser enviado para o Piloto Automático. A definição destas variáveis para manobras ascendentes, descendentes, e curvas niveladas juntamente com os seus cálculos, estão também detalhadas na seção 5.3. O Sistema de Navegação também calcula o ângulo de correção de deriva quando a aeronave sai da rota original devido à rajadas de vento. O cálculo deste ângulo é apresentado na seção 5.4. Finalmente, na seção 5.5 são apresentadas as considerações finais deste capítulo.

\subsection{Parâmetros da Aeronave do Projeto ARARA}

O Sistema de Navegação do projeto ARARA utiliza diversos parâmetros para calcular e definir o conjunto de manobras básicas a serem realizadas pelo Piloto Automático. Os parâmetros podem ser operacionais ou não operacionais, conforme apresentado nas seções 
5.2.1 e 5.2.2, respectivamente.

\subsubsection{Parâmetros Operacionais}

Cada aeronave possui um conjunto de características que dependem do projeto da sua estrutura e da sua aerodinâmica. Estas características são denominadas parâmetros operacionais e são obtidas através de ensaios em condições padronizadas. A aeronave é pilotada, seja por um piloto humano ou por um piloto automático, de acordo com os valores destes parâmetros.

Na aeronave do Projeto ARARA, os valores dos parâmetros operacionais devem ser configurados no Piloto Automático antes do primeiro vôo. Somente os parâmetros operacionais utilizados pelo Sistema de Navegação são citados neste trabalho. São eles:

$\rightarrow \mathrm{Vy}$ - Velocidade da melhor razão de subida: velocidade da aeronave na qual se obtém a melhor taxa de subida. A aeronave obtém o maior ganho de altitude possível em um dado período de tempo.

Mts - Melhor taxa de subida: componente de velocidade vertical da melhor taxa subida.

$\rightarrow$ Vcr - Velocidade de cruzeiro: velocidade constante atingida quando a aeronave realiza um vôo em linha reta, com altitude constante e com as quatro forças principais balanceadas, ou seja, o peso igual à sustentação e o arrasto igual à tração do motor.

$\downarrow$ Vne - Velocidade máxima: máxima velocidade suportada pela aeronave. Se for excedida, a aeronave pode sofrer danos ou falhas estruturais.

$\rightarrow \mathrm{Rg}$ - Raio grande: raio de curva com pequena inclinação da asa $\left(15^{\circ}\right)$.

$\rightarrow \mathrm{Rm}$ - Raio médio: raio de curva com média inclinação da asa $\left(30^{\circ}\right)$.

$\rightarrow \mathrm{Rp}$ - Raio pequeno: raio de curva com grande inclinação da asa $\left(45^{\circ}\right)$. 


\subsubsection{Parâmetros Não Operacionais}

Os parâmetros não operacionais definidos para o Sistema de Navegação do projeto ARARA são:

† Vd - Velocidade de descida: velocidade alcançada pela aeronave em um vôo descendente. Esta velocidade não deve ser maior que a velocidade máxima (Vne).

$\downarrow$ Td - Taxa de descida: componente de velocidade vertical da taxa de descida.

† Dnv - Distância para nivelamento: distância necessária para o nivelamento da aeronave na altitude do waypoint de destino após vôos ascendentes e descendentes.

O parâmetro Dnv foi definido neste trabalho para que a aeronave sempre possa alcançar o waypoint de destino nivelada, conforme ilustra a figura 5.1.

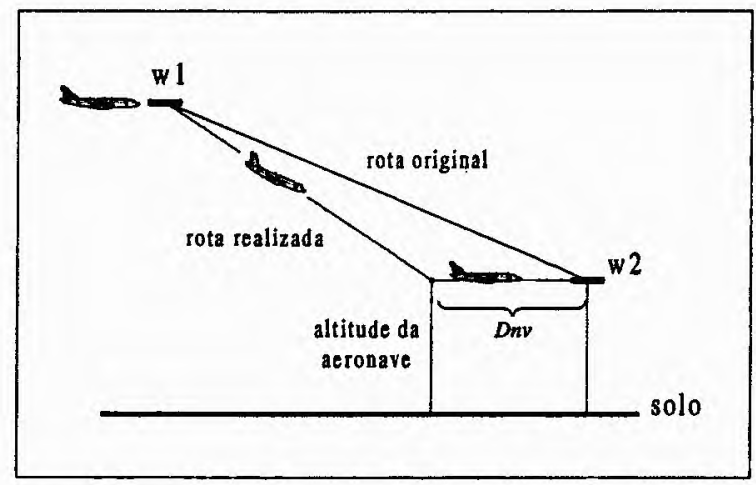

Figura 5.1 - Nivelamento da aeronave ao waypoint de destino, w2.

\subsubsection{Estimativa dos Parâmetros}

Os valores dos parâmetros não operacionais, por não terem sido definidos e testados previamente, normalmente não são compatíveis com situações reais de vôo da aeronave. Foi definido que os valores destes parâmetros devem ser estimados a partir de valores iniciais configurados, pelo usuário no Sistema de Navegação. Após algumas estimativas baseadas em valores medidos durante o vôo, os valores dos parâmetros devem refletir de forma mais precisa o desempenho da aeronave.

Os valores dos parâmetros operacionais também devem ser estimados porque a 
aeronave pode não realizar as manobras estritamente de acordo com esses parâmetros. Por exemplo, o valor do parâmetro Mts (melhor taxa de subida) talvez não seja atingido devido a fatores ambientais como correntes de vento verticais. Com a estimativa deste parâmetro, o fator velocidade do vento pode ser levado em consideração.

Inicialmente, o Sistema de Navegação obtém os valores dos parâmetros configurados no Piloto Automático (parâmetros operacionais) e os valores dos parâmetros configurados na sua própria interface (parâmetros não operacionais) para calcular as manobras básicas. $O$ valor efetivo de um parâmetro, após a realização de manobras, é armazenado em uma tabela. Na próxima utilização deste parâmetro, o seu valor é estimado a partir dos $\mathrm{N}$ últimos valores medidos. Propōe-se neste trabalho que a estimativa para um parâmetro seja dada por:

$$
\left\{\begin{array}{l}
\bar{P}=P_{\text {inicial }} ; \text { na primeira leitura } . \\
\bar{P}=\frac{(N-1) P+P_{L}}{N} ; \text { após cada leitura } P_{L} .
\end{array}\right.
$$

onde

$\bar{P}$ é o parâmetro a ser estimado;

$P_{\text {inicial }}$ é o parâmetro configurado pelo usuário;

$N$ é o número de leituras consideradas na média.

Os parâmetros que serão estimados e suas novas nomenclaturas são:

$\overline{V y}$ - estimativa da velocidade de melhor razão de subida;

$\overline{M t s}$ - estimativa da melhor taxa de subida;

$\overline{V c r}$ - estimativa da velocidade de cruzeiro;

$\overline{V d}$ - estimativa da velocidade de descida;

$\overline{T d}$ - estimativa da taxa de descida.

\subsection{Manobras Básicas}

A rota a ser seguida pela aeronave, fornecida pelo módulo Planejador de Missão, é descomposta em pares de waypoints pelo Sistema de Navegação. O trecho de rota 
compreendido entre cada par de waypoints é decomposto em manobras básicas que são enviadas ao Piloto Automático para serem realizadas pela aeronave. O Sistema de Navegação monitora a execução das manobras e caso o resultado da sua realização não coincidir com o resultado esperado, o sistema calcula um novo conjunto de manobras e o envia ao piloto automático. As manobras básicas definidas para uma aeronave do projeto ARARA são:

Vôo nivelado: a aeronave deve voar em linha reta, horizontalmente em relação ao solo, com as asas niveladas (sem inclinação lateral). A direção e a altitude da aeronave devem ser mantidas constantes. A velocidade utilizada é a velocidade de cruzeiro (Vcr).

+ Vóo ascendente: a aeronave descreve uma trajetória reta, com as asas niveladas, ganhando altitude. A direção deve ser mantida constante e a velocidade utilizada.é a velocidade de melhor razão de subida (Vy).

$\rightarrow$ Vôo descendente: a aeronave descreve uma trajetória reta, com as asas niveladas, perdendo altitude. A direção é constante e a velocidade aplicada é a velocidade de descida (Vd).

† Vôo em curva nivelado: a aeronave deve manter a altitude constante. A direção da curva pode ser esquerda ou direita e o raio pequeno, médio ou grande.

$\rightarrow$ Abortar missão: esta manobra deve ser realizada se ocorrer falha em qualquer um dos sistemas, sensores ou motor da aeronave. O piloto automático deve desligar o motor e acionar o pára-quedas.

$\rightarrow$ Finalizar missão: é realizada ao término de uma missão. A aeronave deve ser estabilizada e nivelada, o motor desligado e o pára-quedas acionado pelo piloto automático.

+ Glissagem: manobra que permite a aeronave deslizar lateralmente em sua trajetória. Esta manobra é aplicada à aeronave quando o vento a desvia de sua rota original. É aplicado um ângulo de correção de deriva na proa da aeronave (seção 5.8) permitindo que a mesma possa deslizar lateralmente em direção ao waypoint de destino. 
Para padronizar as manobras a serem calculadas pelo Sistema de Navegação em diferentes situações de vôo, foi especificado que as curvas realizadas pela aeronave deverão ser em nível, qualquer que seja a diferença de altitude entre o waypoint de origem e 0 waypoint de destino, ou seja, não serão realizadas curvas ascendentes ou descendentes. A razão para a adoção de curvas niveladas é a pequena diferença de tempo entre a execução de uma curva ascendente e a execução de uma curva nivelada seguida de um vôo ascendente

\subsubsection{Classificação das Manobras Básicas}

As manobras básicas são classificadas em manobras de curso, mianobras de adaptação e manobras de correção. Cada conjunto de manobras trata diferentes situações de vôo.

As manobras de curso são apenas combinações de manobras básicas. Estas manobras são realizadas quando a distância entre o waypoint de origem e o waypoint de destino é suficiente para a realização de manobras básicas sem nenhuma adaptação.

As manobras de adaptação são constituídas por um conjunto de manobras básicas e um conjunto de waypoints intermediários que são inseridos na rota original com a finalidade de adaptá-la para que a aeronave tenha condições de sobrevoar o par de waypoints. Estas manobras são realizadas quando a distância entre 0 waypoint de origem e 0 waypoint de destino não é suficiente para que sejam realizadas apenas manobras de curso. A distância não é suficiente quando os valores, dos parâmetros operacionais e não operacionais da aeronave não permitem o alcance do waypoint de destino, a partir do waypoint de origem.

As manobras de correção são realizadas para corrigir a posição da aeronave caso ela desvie da rota original devido a rajadas de vento (seção 5.4).

\subsubsection{Análise das Manobras Básicas}

Para definir o conjunto de manobras a ser realizado entre um par de waypoints, o Sistema de Navegação deve analisar algumas variáveis que são dependentes do tipo de manobra básica a ser realizada. As variáveis estão ilustradas na figura 5.2 e descritas a seguir.

D - distância horizontal entre o waypoint de origem, w1, e o waypoint de destino, w2; 
DN - distância horizontal necessária para a realização de uma manobra entre um par de waypoints (não está ilustrada na figura);

Di - distância horizontal entre o waypoint de origem, w1, e o waypoint intermediário, wi, distanciado Dnv do waypoint de destino. Esta distância é necessária porque a aeronave deve chegar ao waypoint de destino nivelada, sendo necessário, então, de uma distância de nivelamento, Dnv. Então Di é dada por $D i=D-D n v$;

$\Delta \mathbf{A}$ - diferença de altitude entre o waypoint de destino e o waypoint de origem;

$\theta$ - ângulo horizontal formado entre a aeronave e o trecho de rota compreendido entre o waypoint de origem e o waypoint de destino. Os valores de $\theta$ aumentam no sentindo horário e podem variar entre $0^{\circ}$ e $360^{\circ}$.

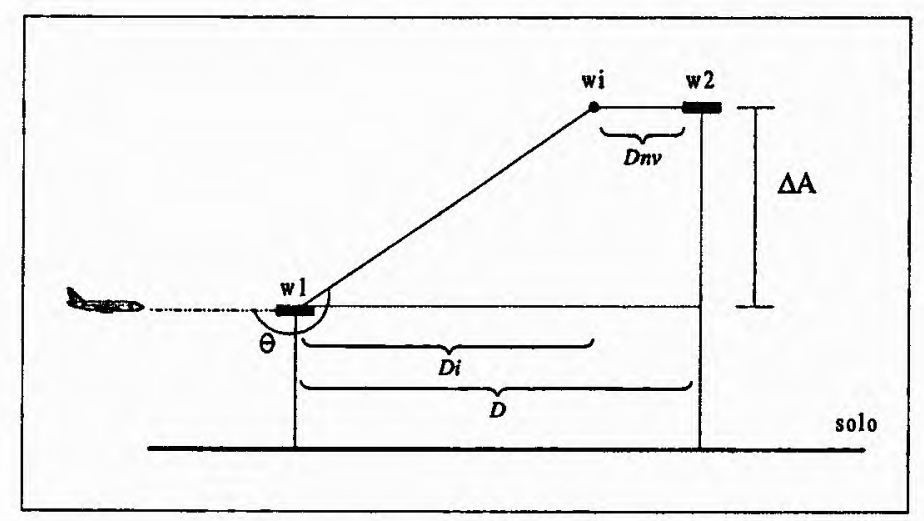

Figura 5.2 - Variáveis que definem o conjunto de manobras.

A variável DN é calculada e analisada pelo Sistema de Navegação quando as manobras a serem realizadas são vôos ascendentes, descendentes ou curvas niveladas. Sua nomenclatura é diferenciada para refletir cada tipo de manobra, ou seja:

DNa - Distância necessária para a realização de vôos ascendentes

DNd - Distância necessária para a realização de vôos descendentes

DNc - Distância necessária para a realização de curvas niveladas

\subsubsection{Cálculo de D}

O cálculo de $\mathrm{D}$ é o mesmo para qualquer tipo de manobra, pois trata-se da distância 
horizontal entre dois waypoints, ou seja, as altitudes dos waypoints não são levadas em consideração. A distância D entre dois waypoints, a partir de suas coordenadas em latitude $\mathrm{e}$ longitude, é dada pela equação 5.1 [LOG92, RIB00]:

$$
D=2 \times \operatorname{ArcSen}\left(\sqrt{\left(\frac{\operatorname{sen}(\text { Lat } 1-\text { Lat } 2)}{2}\right)^{2}+\cos (\text { Lat } 1) \times \cos (\text { Lat } 2) \times\left(\frac{\operatorname{sen}(\text { Long } 1-\text { Long } 2)}{2}\right)^{2}}\right)
$$

onde Lat1 e Long1 são as coordenadas do waypoint de origem e Lat2 e Long2 são as coordenadas do waypoint de destino.

Também é possível calcular D utilizando a equação 5.2, entretanto a mesma tem pouca precisão para distâncias pequenas [LET98]:

$$
D=\operatorname{ArcCos}(\operatorname{sen}(\text { Lat } 1) \times \operatorname{sen}(\text { Lat } 2)+\cos (\text { Lat } 2) \times \cos (\text { Long } 1-\text { Long } 2))
$$

\subsubsection{Análise das Manobras Ascendentes}

Para a reałização de manobras ascendentes, é necessário o cálculo e a análise das distâncias $\mathrm{D}$, Di e $\mathrm{DNa}$ e da diferença de altitude, $\triangle \mathrm{A}$, que é dada por $\Delta \mathrm{A}=\mathrm{A}_{2}-\mathrm{A}_{1}$, onde $\mathrm{A}_{1}$ é a altitude do waypoint de origem e $\mathrm{A}_{2}$ é a altitude do waypoint de destino. A Figura 5.3 ilustra os casos possíveis.

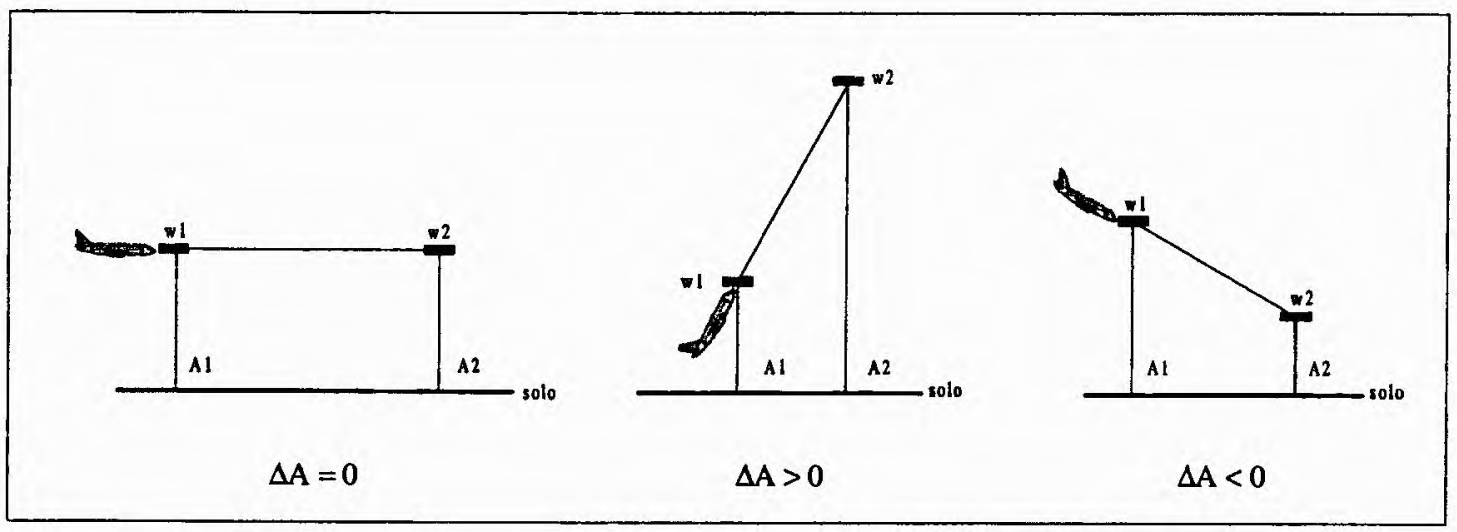

Figura 5.3 - Possíveis diferenças de altitude entre w1 e w2. 


\subsubsection{Cálculo de DNa}

A aeronave deve sempre alcançar o waypoint de destino nivelada, sendo necessário o cálculo do valor de Di que é dado por:

$$
D i=D-D n v
$$

O movimento da aeronave de $w_{1}$ para $w_{2}$, representado na figura 5.4 , pode ser decomposto em dois movimentos: de $w_{1}$ para $w_{x}$ e de $w_{x}$ para $w_{2}$. $O$ vetor velocidade da aeronave na direção $\overrightarrow{w_{1} w_{2}}$ pode ser decomposto em duas componentes perpendiculares, nas direções $\overrightarrow{w_{1} w_{x}}$ e $\overrightarrow{w_{x} w_{2}}$. As equações de velocidade para os dois movimentos são:

$$
\begin{aligned}
& \overline{M t s}=\Delta A / \Delta t \\
& \overline{V y}=D N a / \Delta t
\end{aligned}
$$

onde

$\mathrm{DNa}$ é a distância necessária para que a aeronave possa alcançar w2 a partir de w1;

$\overline{M t s}$ é a estimativa da máxima taxa de subida;

$\Delta \mathrm{A}$ é a diferença de altitude entre os waypoints wl e w2;

$\overline{V y}$ é a estimativa da velocidade de melhor razão de subida.

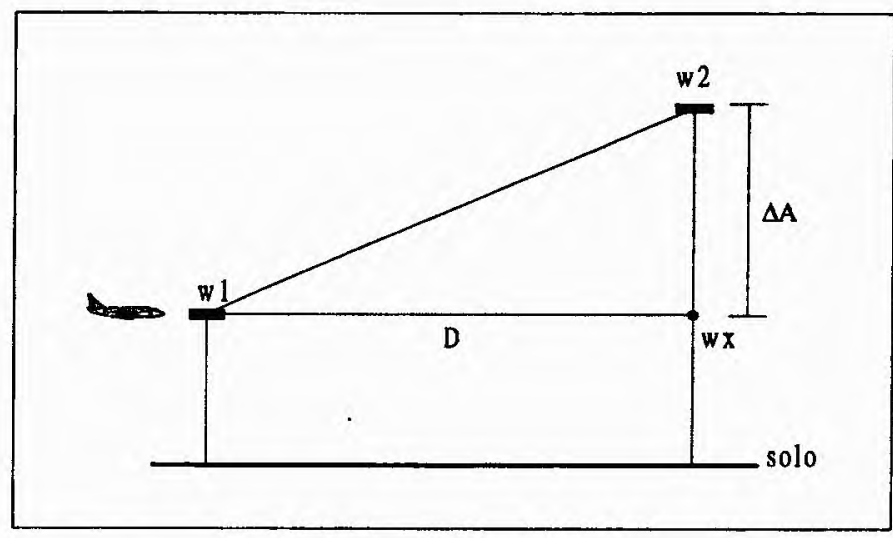

Figura 5.4 - Decomposição do vetor velocidade.

Considerando que o tempo de percurso é igual para os dois movimentos, pode-se então igualar as equações (5.4) e (5.5) e obter DNa: 


$$
D N a=\overline{V y} \times \Delta \mathrm{A} / \overline{\mathrm{M} t s}
$$

Se Di não for suficiente para que a aeronave alcance o waypoint de destino a partir do waypoint de origem em um vôo ascendente, ou seja, $D i<D N a$, a aeronave deverá realizar um conjunto de manobras de adaptação, caso contrário ela realizará um conjunto de manobras de curso. Os conjuntos de manobras para cada situação de vôo estão descritos no apêndice B.

A análise de manobras descendentes é análoga à análise para manobras ascendentes, diferenciando apenas nas variáveis de velocidade.

\subsubsection{Análise de Curvas Niveladas}

A manobra de curva nivelada requer uma distância DNc entre o waypoint de origem e o waypoint de destino específica para cada valor de $\theta$. A distância $D$ entre o par de waypoints deve ser suficiente para permitir a realização da curva, ou seja, $D \geq D N c$. Se a distância não for suficiente, a aeronave deverá realizar manobras de adaptação.

\subsubsection{Rota Quadrilátera}

Existem muitas sịtuações de vôo onde a aeronave não consegue percorrer a rota original em toda a sua extensão devido aos valores do ângulo de chegada, da diferença de altitude entre os waypoints de origem e destino e da distância existente entre eles. Para tratar estes casos, foi adotada uma rota quadrilátera para que a aeronave possa percorrer todos os waypoints da missão, realizando as tarefas inerentes a cada waypoint. As manobras de adaptação fazem a aeronave percorra uma trajetória na forma de um quadrilátero onde os valores dos lados são calculados de acordo com os diferentes valores de $\theta, \mathrm{D}, \mathrm{DNc}, \mathrm{DNa}$, DNd e $\triangle$ A.

A figura 5.5 mostra as manobras para $\theta$ igual a $45^{\circ}, 135^{\circ}, 225^{\circ}$ e $315^{\circ}$. No apêndice $B$ são mostradas as demais possibilidades. Para valores de $\theta$ nos intervalos $0^{\circ} \leq \theta<90^{\circ}$ e $270^{\circ}<\theta \leq 360^{\circ}$ são realizadas rotas quadriláteras, independente se a distância entre o waypoint de origem e o waypoint de destino é suficiente ou não. Para valores de $\theta$ nos intervalos $90^{\circ} \leq \theta<180^{\circ}$ e $180^{\circ}<\theta \leq 270^{\circ}$ poderão ser realizadas curvas normais, sem 
adaptação, conforme ilustrado na figura 5.5.

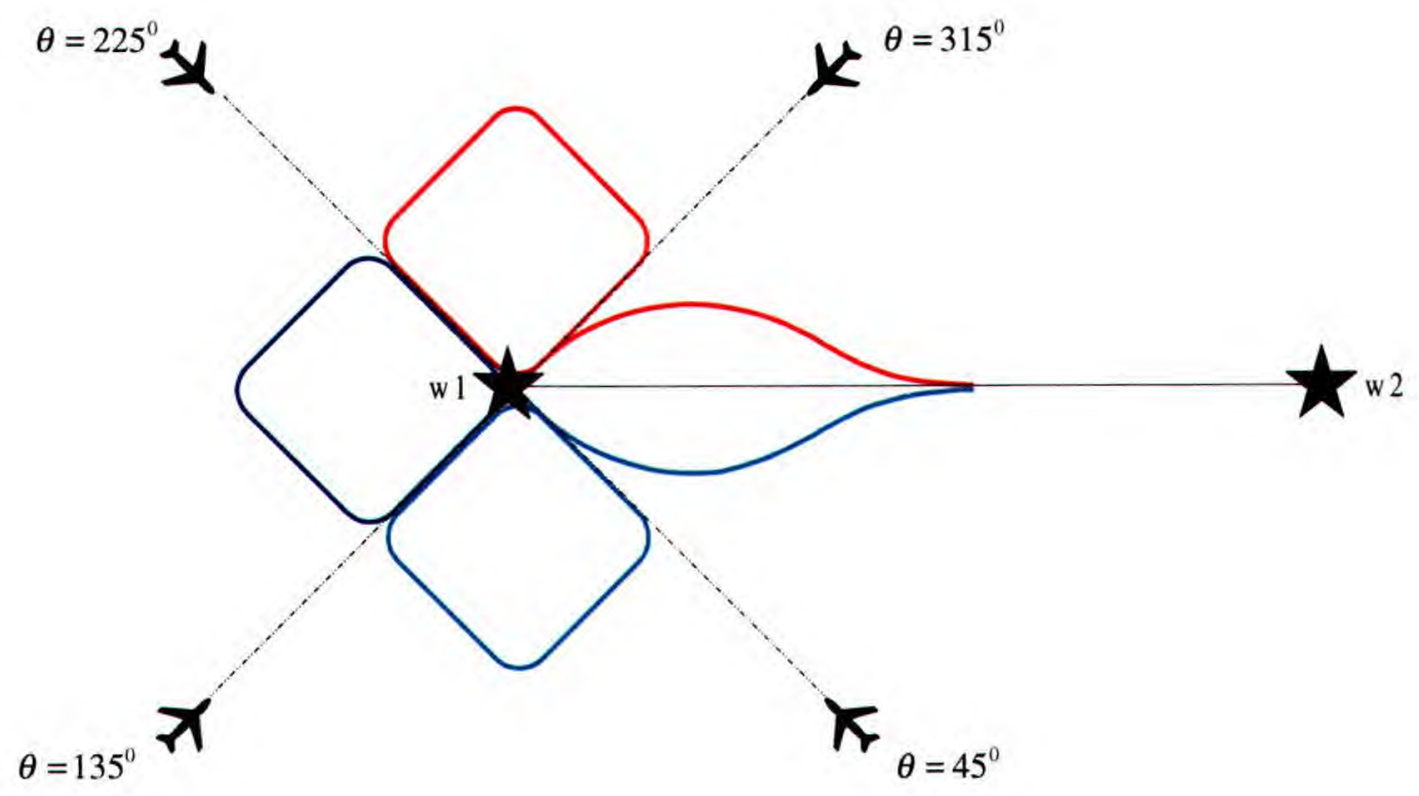

Figura 5.5 - Síntese das manobras para $\theta$ igual a $45^{\circ}, 135^{\circ}, 225^{\circ}$ e $315^{\circ}$.

A especificação da rota quadrilátera deve-se ao fato de seus ângulos internos serem iguais a $90^{\circ}$. A maior parte das curvas a serem realizadas é igual a $90^{\circ}$. As situações de vôo onde é necessário adotar uma rota quadrilátera são:

$\rightarrow \mathrm{O}$ valor do ângulo de chegada $\theta$ estiver nos intervalos $0^{\circ} \leq \theta<90^{\circ}$ e $270^{\circ}<\theta \leq 360^{\circ}$. A aeronave irá realizar somente curvas menores ou iguais a $90^{\circ}$;

$\rightarrow \mathrm{O}$ valor do ângulo de chegada $\theta$ estiver nos intervalos $90^{\circ} \leq \theta<180^{\circ}$ e $180^{\circ}<\theta \leq 270^{\circ}$ e a distância D entre o waypoint de origem e o waypoint de destino é menor que a distância DNc, distância necessária para a realização de curvas.

$\rightarrow \mathrm{O}$ valor do ângulo de chegada $\theta$ estiver nos intervalos $90^{\circ} \leq \theta<180^{\circ}$ e $180^{\circ}<\theta \leq 270^{\circ}$ e a distância Di entre o waypoint de origem e o waypoint intermediário é menor que as distâncias DNa ou DNd, distâncias necessárias para a realização de vôos ascendentes e descendentes, respectivamente.

$\rightarrow \mathrm{O}$ valor do ângulo de chegada $\theta$ estiver nos intervalos $90^{\circ} \leq \theta<180^{\circ}$ e 
$180^{\circ}<\theta \leq 270^{\circ}$ e a distância D entre o waypoint de origem e o waypoint de destino é menor que a soma entre a distância necessária para a realização de curvas, DNc, e a distância necessária para a realização de vôo ascendente ou descendente, $\mathrm{DNa}$ ou DNd.

O comprimento $\mathrm{L}$ de um lado do quadrilátero deve ser:

- Suficiente apenas para realizar a rota no formato de um quadrilátero. Cada lado deve ser maior que a soma da distância necessária para a estabilização da aeronave após uma curva, conforme ilustra da figura 5.6.

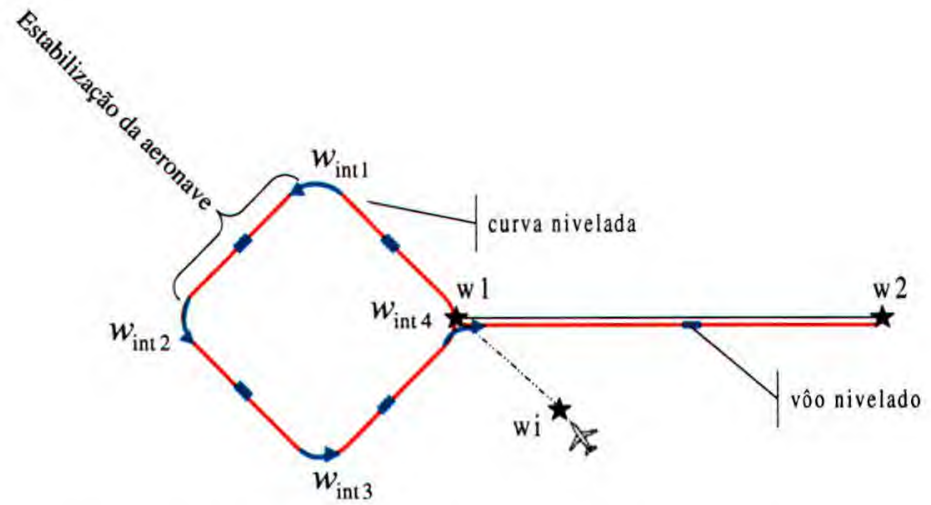

Figura 5.6 - Menor distância para o lado de um quadrilátero.

$\rightarrow$ Suficiente para atender o item anterior e aumentar a distância entre a aeronave e o waypoint de destino em situações onde esta distância não é suficiente para a realização de uma manobra ascendente ou descendente. Neste caso, cada lado do quadrilátero deve ter o valor dado pela expressão abaixo e ilustrado na figura 5.7:

$$
L=D e s t+D c / 4
$$

onde

Dest é a distância necessária para a estabilização da aeronave após curvas;

Dc é a distância que complementa a distância necessária para a realização de uma manobra ascendente ou descendente e é dada por $D c=D-D N a($ ou $D N d)$. 


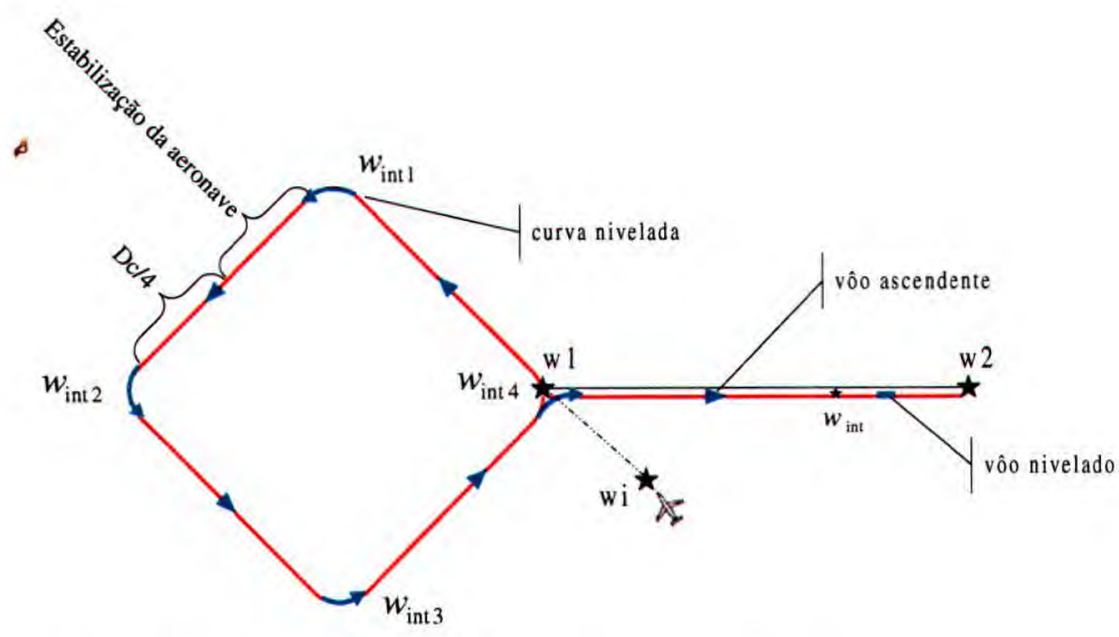

Figura 5.7 - Distância máxima para o lado de um quadrilátero.

\subsubsection{Cálculo de DNc}

Quando $\theta$ está nos intervalos $90^{\circ} \leq \theta<180^{\circ}, 180^{\circ}<\theta \leq 270^{\circ}$ e a distância D entre o waypoint de origem e o waypoint de destino é maior ou igual que a distância DNc, distância necessária para a realização de curvas, é possível simplificar a manobra necessária para a mudança de curso da aeronave, conforme ilustrado na figura 5.5.

É necessário neste caso calcular o valor de DNc e dos ângulos das curvas realizadas pela aeronave. A situação de vôo analisada para o cálculo está ilustrada na figura 5.8 onde a aeronave deve realizar duas curvas, uma a direita e outra a esquerda. A diferença de altitude entre os waypoints, neste caso, é igual a zero.

As curvas realizadas pela aeronave na figura 5.8 fazem de circunferências idênticas, $\mathrm{C}_{1}$ e $\mathrm{C}_{2}$ e raio $\mathrm{r}$, que se tangenciam no ponto $\mathrm{P}$. Foi também inserida uma circunferência maior, $\mathrm{C}$, centrada em $\mathrm{C}_{1}$ e passando pelo centro de $\mathrm{C}_{2}$, conforme ilustra a figura 5.9. Os raios das circunferências são um dos três raios, $\mathrm{Rg}, \mathrm{Rm}$ ou $\mathrm{Rp}$, especificados nos parâmetros operacionais da aeronave. 


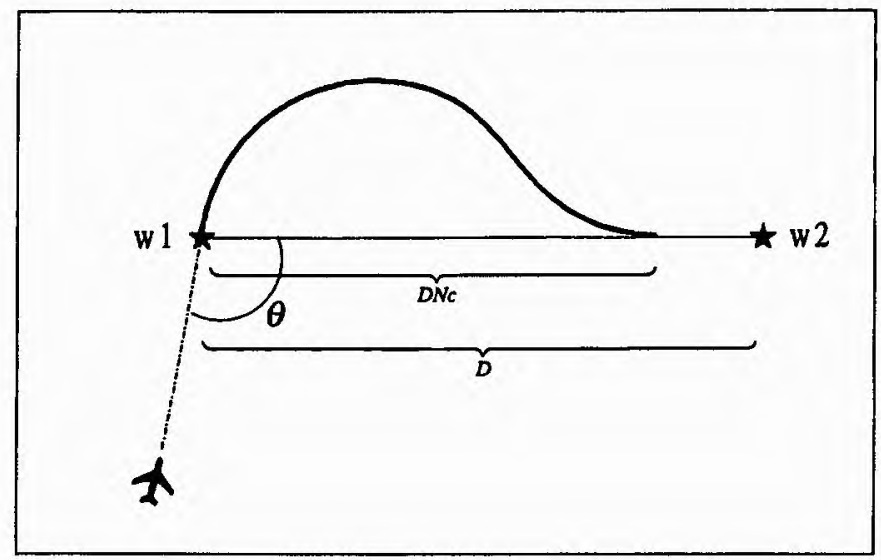

Figura 5.8 - Situação de vôo a ser analisada para o cálculo de DNc.

Considere-se a seguinte nomenclatura para as coordenadas dos centros das circunferências da figura 5.9:

$$
\begin{aligned}
& C_{1}=C=\left(x_{1}, y_{1}\right) \\
& C_{2}=\left(x_{2}, y_{2}\right)
\end{aligned}
$$

De acordo com a figura 5.9, os valores das coordenadas $x_{1}, y_{1}, x_{2}$ e $y_{2}$ são:

$$
\begin{aligned}
& x_{1}=r \cos \varphi \\
& y_{1}=-r \operatorname{sen} \varphi \\
& x_{2}=D N c \\
& y_{2}=r
\end{aligned}
$$

onde

$$
r \text { é o raio das curvas; }
$$

$\varphi$ é dado por $\varphi=\theta-90^{\circ}$;

$D N c$ é a distância que se deseja calcular. 


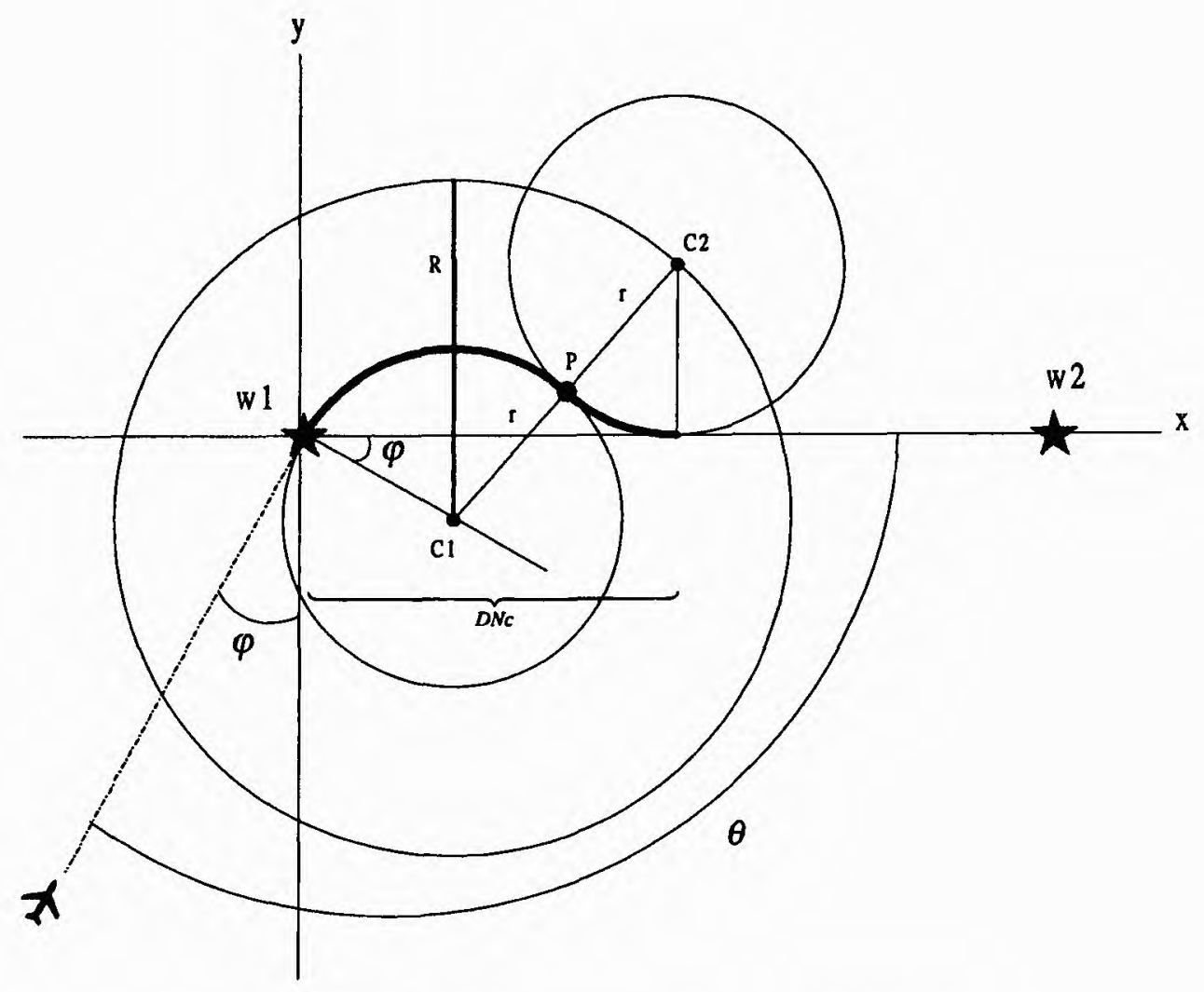

Figura 5.9 - Circunferências para auxiliar no cálculo de DNc.

Escrevendo a equação da circunferência maior, tem-se:

$$
\left(x-x_{1}\right)^{2}+\left(y-y_{1}\right)^{2}=R^{2}
$$

onde $x$ e $y$ são as coordenadas de um ponto pertencente à circunferência que na figura 5.6 tem centro em $C_{2}$ e raio $\mathrm{R}$ igual a $2 \mathrm{r}$. Substituindo as igualdades 5.8 e o valor de $\mathrm{R}$ na equação 5.9 , obtém-se a seguinte equação:

$$
(D N c-r \cos \varphi)^{2}+(r+r \operatorname{sen} \varphi)^{2}=(2 r)^{2}
$$

A equação 5.10 é uma equação do $2^{\circ}$ grau em função da variável DNc:

$$
D N c^{2}-b D N c+c=0
$$

onde

$$
b=2 r \cos \varphi
$$




$$
c=2 r^{2} \operatorname{sen} \varphi-2 r^{2}
$$

A resolução da equação 5.11 sempre fornecerá uma raiz positiva e uma negativa. De acordo com a figura 5.9, a raiz positiva é a raiz procurada, pois DNc é o valor da coordenada $\mathrm{x}$ do ponto $\mathrm{C} 2$ que sempre estará no primeiro quadrante, para $0^{\circ}<\varphi<90^{\circ}$.

\subsubsection{Cálculo dos Ângulos das Curvas}

Sejam os pontos e suas coordenadas:

$$
\begin{aligned}
& C_{1}=\left(x_{1}, y_{1}\right) \\
& C_{2}=\left(x_{2}, y_{2}\right) \\
& W_{1}=\left(x_{w}, y_{w}\right)
\end{aligned}
$$

Os vetores $\overrightarrow{C_{1} C_{2}}$ e $\overrightarrow{C_{1} W_{1}}$, ilustrados na figura 5.10 , são dados por:

$$
\begin{aligned}
& \overrightarrow{C_{1} C_{2}}=C_{2}-C_{1}=\left(x_{2}-x_{1}, y_{2}-y_{1}\right) \\
& \overrightarrow{C_{1} W_{1}}=W_{1}-C_{1}=\left(x_{w}-x_{1}, y_{w}-y_{1}\right)
\end{aligned}
$$

$O$ ângulo $\beta$ da primeira curva, formado entre os vetores 5.13 e 5.14 , ilustrado na figura 5.10, é dado por [STE87]:

$$
\cos \beta=\frac{\overrightarrow{C_{1} C_{2}} \cdot \overrightarrow{C_{1} W_{1}}}{\left|\overrightarrow{C_{1} C_{2}}\right|\left|\overrightarrow{C_{1} W_{1}}\right|}
$$

Se $\overrightarrow{C_{1} C_{2}} \cdot \overrightarrow{C_{1} W_{1}}>0$ então $\cos \beta>0$ e $0 \leq \beta<\frac{\pi}{2}$. Se $\overrightarrow{C_{1} C_{2}} \cdot \overrightarrow{C_{1} W_{1}}<0$ então $\cos \beta<0$ $\mathrm{e} \frac{\pi}{2}<\beta<\pi$

$O$ valor do ângulo $\gamma$ da segunda curva pode ser obtido a partir do quadrilátero da figura 5.10. Somando os ângulos internos do quadrilátero, obtém o valor de $\alpha$ :

$$
\left(90^{\circ}+\varphi\right)+\beta+\alpha+90^{\circ}=360^{\circ}
$$

O valor de $\gamma$ é dado por $90^{\circ}-\alpha$. 


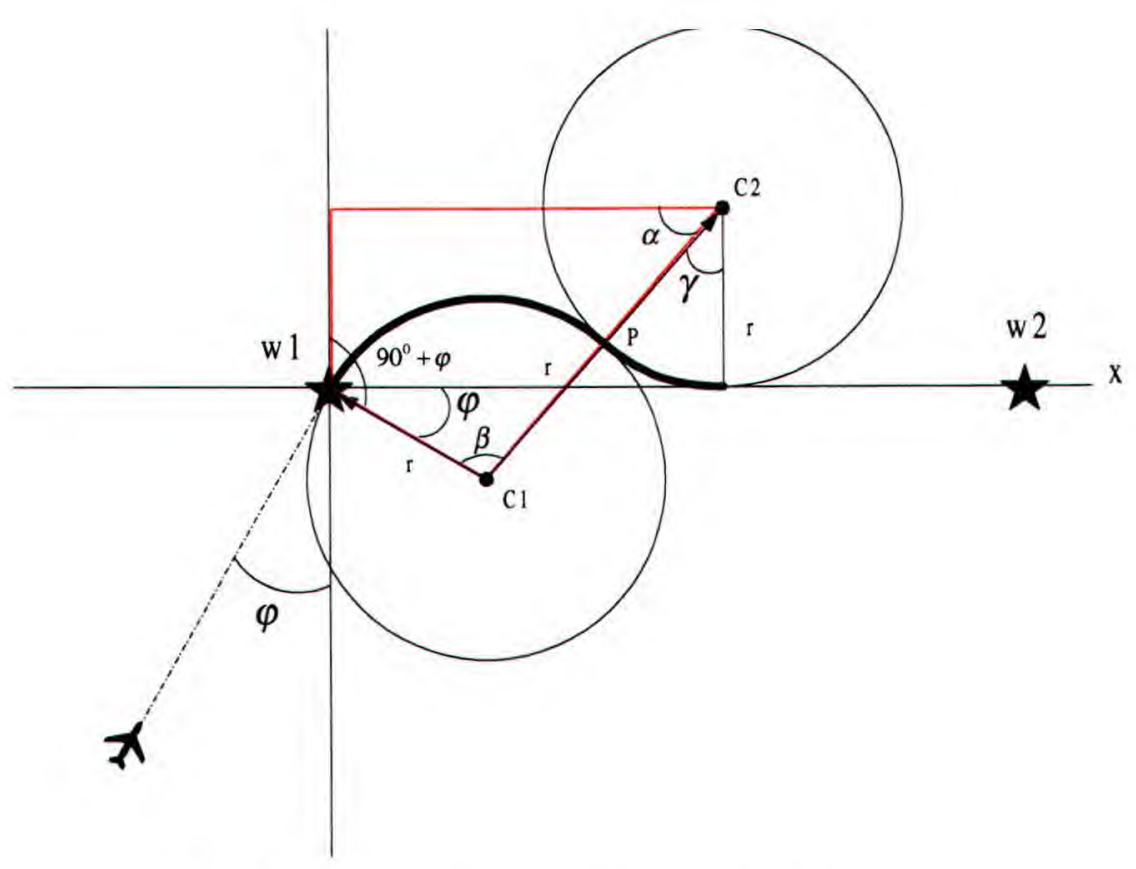

Figura 5.10 - Ângulos das curvas a serem realizadas pela aeronave.

\subsubsection{Síntese dos Conjuntos de Manobras para Diferentes Valores de $\theta$}

A seguir são sintetizados todos os conjuntos de manobras calculados pelo Sistema de Navegação para os possíveis valores de $\theta$. A diferença de altitude, $\triangle \mathrm{A}$, nos casos abaixo, é igual a zero. No apêndice $B$ estão descritas todas as manobras com $\Delta A$ diferente de zero onde são necessários os cálculos de vôos ascendentes e descendentes. O conjunto de manobras para $\theta$ igual a $180^{\circ}$ não se encaixa em nenhum dos conjuntos abaixo. Trata-se de um caso especial que também está descrito no apêndice B.

$0^{\circ} \leq \theta \leq 90^{\circ}\left\{\begin{array}{l}\text { vôo nivelado de comprimento } L \\ \text { curva de } 90^{\circ} \text { à esquerda } \\ \text { vôo nivelado de comprimento } L \\ \text { curva de } 90^{\circ} \text { à esquerda } \\ \text { vôo nivelado de comprimento } L \\ \text { curva de } 90^{\circ} \text { à esquerda } \\ \text { vôo nivelado de comprimento } L \\ \text { curva de } 90^{\circ}-\theta \text { à direita } \\ \text { vôo nivelado até o waypoint de destino }\end{array}\right.$ 


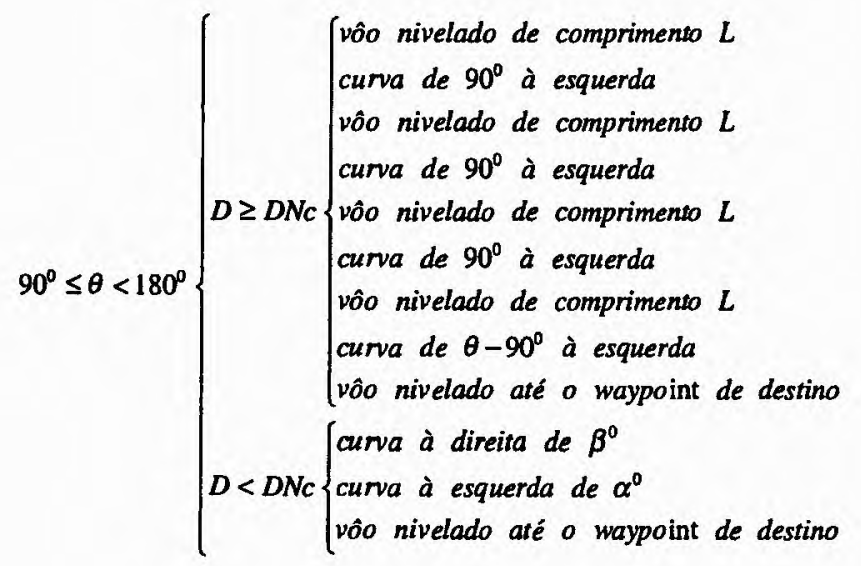

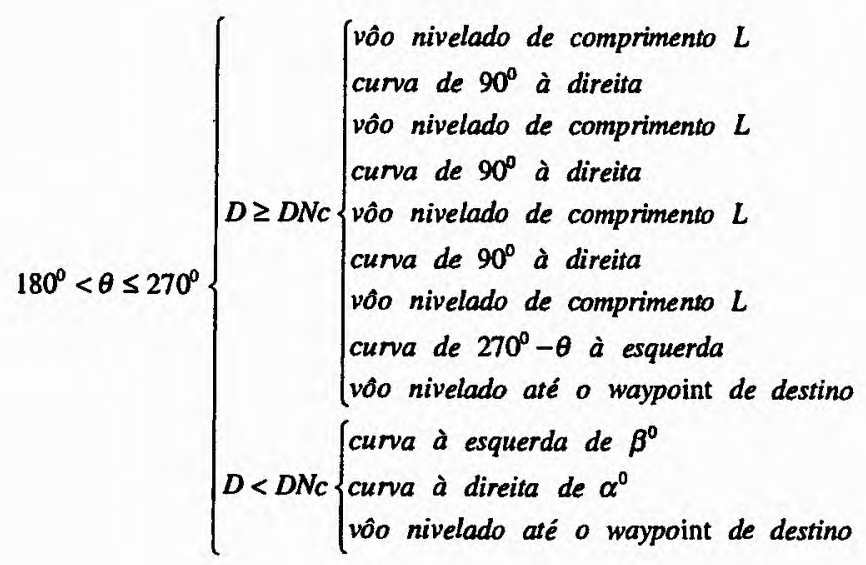

$270^{\circ} \leq \theta<360^{\circ}\left\{\begin{array}{l}\text { vôo nivelado de comprimento } L \\ \text { curva de } 90^{\circ} \text { à direita } \\ \text { vôo nivelado de comprimento } L \\ \text { curva de } 90^{\circ} \text { à direita } \\ v o ̂ o \text { nivelado de comprimento } L \\ \text { curva de } 90^{\circ} \text { à direita } \\ \text { vôo nivelado de comprimento } L \\ \text { curva de } \theta-270^{\circ} \text { à esquerda } \\ \text { vôo nivelado até o waypoint de destino }\end{array}\right.$

\subsection{Análise da Influência do Vento na Trajetória da Aeronave}

\subsubsection{Airspeed, Ground Speed e Wind Speed}

Para analisar a influência do vento sobre a aeronave em vôo, é necessário definir os 
seguintes vetores de velocidade:

†elocidade do vento (wind speed): É a velocidade com que uma massa de ar move-se em relação a um ponto de referência fixo no solo. Este vetor é representado por $\vec{w}$.

Velocidade em relação ao solo (ground speed): velocidade da aeronave em relação a um ponto de referência no solo. Este vetor é representado por $\overrightarrow{g s}$.

Velocidade aerodinâmica (airspeed): velocidade com que a aeronave atravessa uma massa de ar. O vetor velocidade aerodinâmica é representado por $\overrightarrow{v a}$.

A velocidade aerodinâmica da aeronave fornecida pelo velocímetro ${ }^{12}$ não é influenciada pelo vento pois ela é independente de ponto de referência. $O$ vento influencia apenas na velocidade de solo (ground speed). A velocidade aerodinâmica pode ser calculada a partir da velocidade de solo e da velocidade do vento:

$$
\overrightarrow{v a}=\overrightarrow{g s}-\vec{w}
$$

\subsubsection{Tipos de Vento}

$O$ vento pode influenciar na direção e na velocidade da aeronave de três formas, conforme ilustrado na figura 5.11:

† Vento de cauda (tailwind): sopra na mesma direção e no mesmo sentido da aeronave, aumentando sua velocidade em relação ao solo (ground speed). A figura 5.11(a) ilustra os vetores $\overrightarrow{g s}, \overrightarrow{v a}$ e $\vec{w}$ nesta situação.

† Vento de proa (headwind): diminui a velocidade da aeronave em relação ao solo (ground speed), pois a massa de ar na qual a aeronave se desloca está em movimento em direção contrária ao movimento da aeronave. A figura 5.11(b) ilustra os vetores $\overrightarrow{g s}, \overrightarrow{v a}$ e $\vec{w}$ nesta situação.

${ }^{12}$ A velocidade que o velocímetro fornece é denominada velocidade indicada, sem correções. A velocidade aerodinâmica corrigida para a altitude e temperatura é denominada velocidade calibrada. 
$\rightarrow$ Vento de través: sopra lateralmente à trajetória da aeronave, desviando-o de sua rota, ocasionando uma deriva. A velocidade em relação em relação ao solo pode aumentar ou diminuir, dependendo se a componente do vento na direção do movimento da aeronave é de mesmo sentido ou não. A figura 5.11(c) ilustra os vetores $\overrightarrow{g s}, \overrightarrow{v a}$ e $\vec{w}$ com vento de través. Neste caso, o vento de través é perpendicular à velocidade aerodinâmica logo não existe componente de vento na direção do movimento da aeronave.

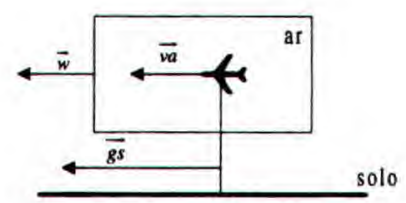

(a)

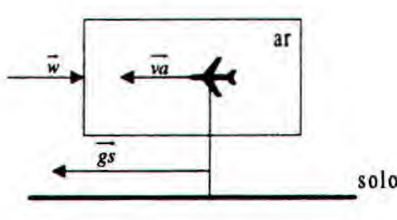

(b)

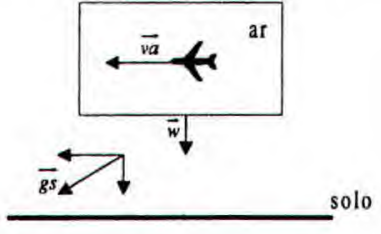

(c)

Figura 5.11 - (a) vento de cauda, (b) vento de cauda e (c) vento de través.

\subsection{3 Ângulo de Correção}

Em geral, uma aeronave voa, ao ser atingida por um vento de través, no mesmo heading, porém descreve uma trajetória diferente da trajetória original. A figura 5.12 ilustra este desvio de trajetória. 


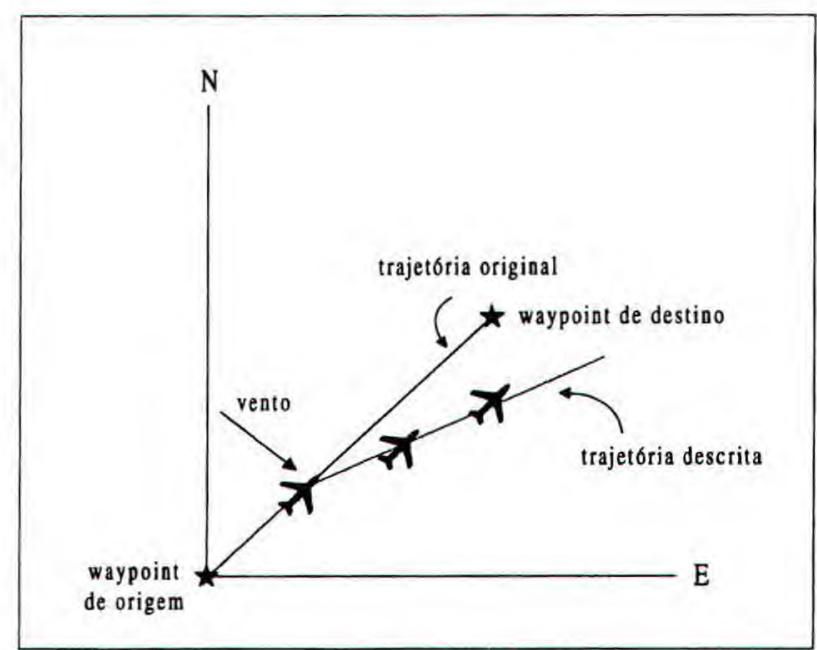

Figura 5.12 - Influência do vento na trajetória da aeronave.

É necessário calcular um novo heading (proa) de modo que a aeronave possa alcançar o waypoint de destino, dada a velocidade do vento $\vec{w}$. Para isso, define-se o ângulo de correção $\beta$ da seguinte forma:

Sejam $\alpha_{0}$ o heading atual da aeronave (após ser atingida pelo vento), $\overrightarrow{v a_{0}}$ a velocidade aerodinâmica atual e $\vec{w}$ a velocidade do vento. $\mathrm{O}$ ângulo de correção $\beta$ é o ângulo que somado ao heading atual, $\alpha_{0}$, resulta num novo heading $\alpha_{1}=\alpha_{0}+\beta$ que, aplicado à aeronave, resultará em uma nova velocidade aerodinâmica $\overrightarrow{v a_{1}}$ tal que a resultante de $\overrightarrow{v a_{1}}$ com $\vec{w}$, ou seja, a nova velocidade em relação ao solo $\left(\overrightarrow{g s_{1}}=\overrightarrow{v a_{1}}+\vec{w}\right)$, tenha heading $\alpha_{0}$. Na figura 5.13(a) é ilustrada uma situação onde o valor do ângulo $\beta$ é positivo e na figura 5.3(b) uma situação onde o valor do ângulo $\beta$ é negativo. 


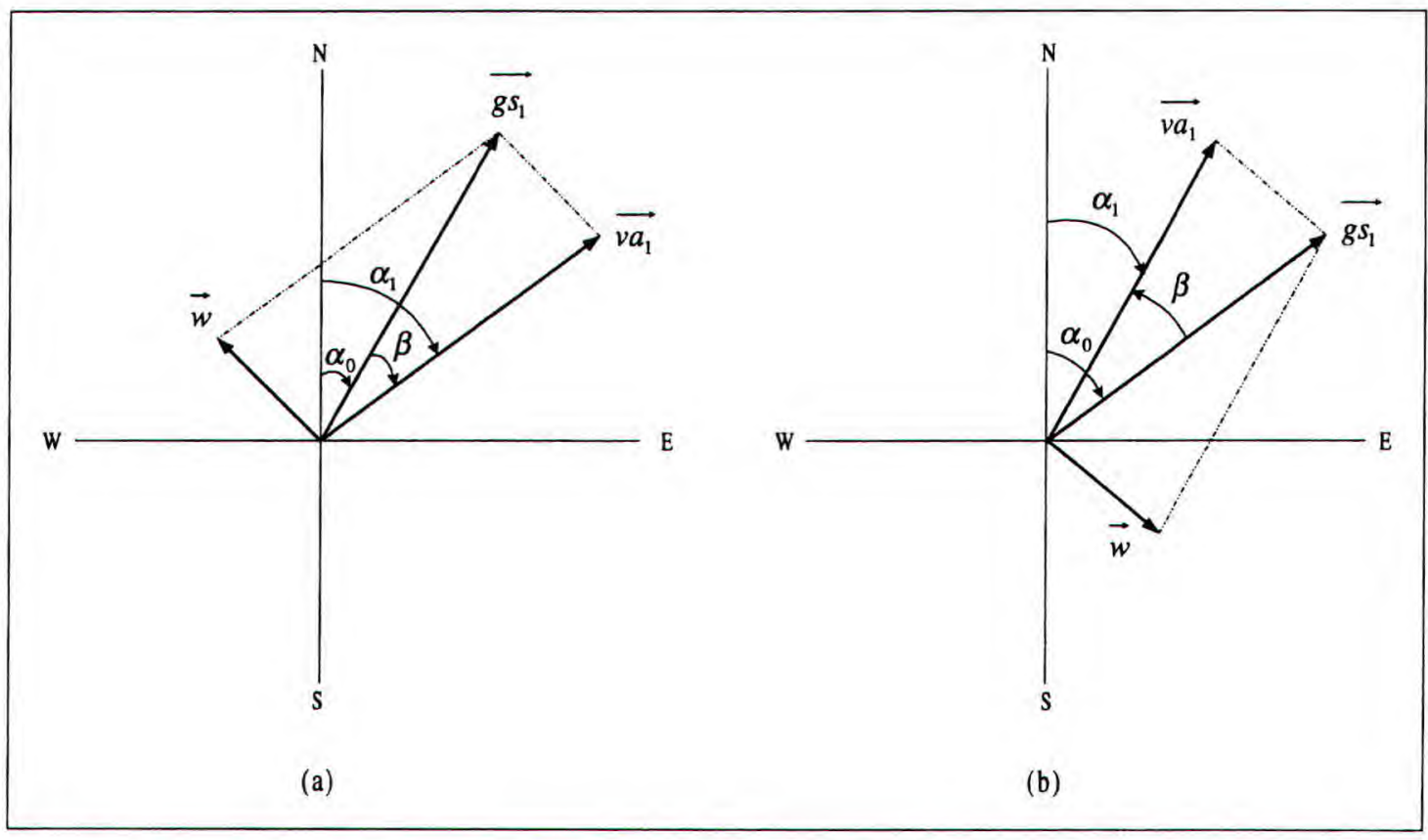

Figura 5.13 - (a) Ângulo de correção $\beta$ positivo e (b) Ângulo de correção $\beta$ negativo.

O cálculo do ângulo $\beta$ torna-se mais fácil rotacionando todos os vetores de $\alpha_{0}$ no sentido anti-horário, conforme ilustra a figura 5.14. 


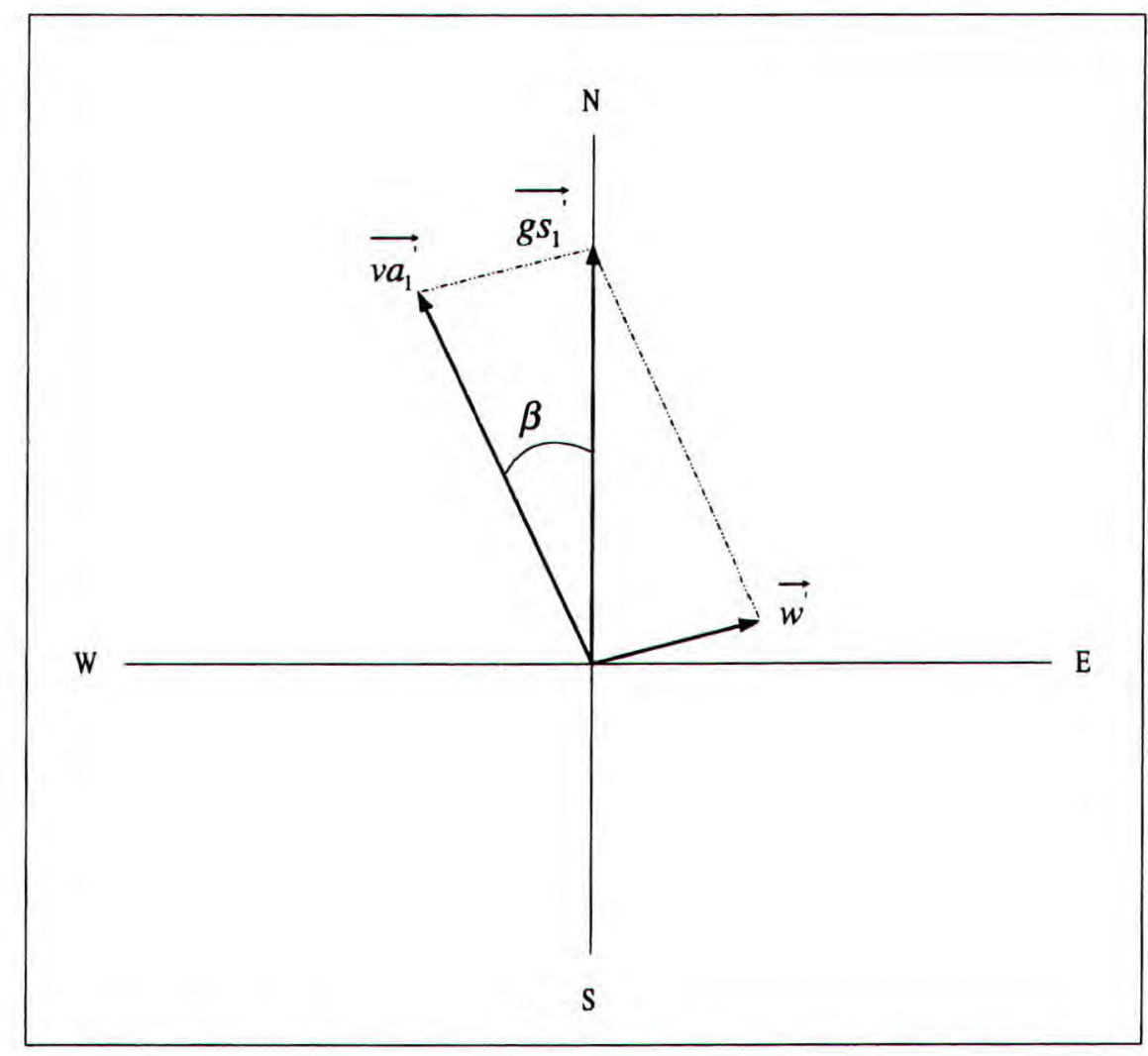

Figura 5.14 - Rotação dos vetores $\overrightarrow{g s_{1}}, \overrightarrow{v a_{1}}$ e $\vec{w}$ de $\alpha_{0}$.

Com a rotação, obtém-se um novo vetor $\overrightarrow{w^{\prime}}$ tal que suas coordenadas, $w_{x}{ }^{\prime}$ e $w_{y}^{\prime}$, são dadas pela multiplicação da matriz de rotação [BOU87, STE87] pela matriz de coordenadas do vetor $\vec{w}$ :

$$
\left(\begin{array}{l}
w_{x}^{\prime} \\
w_{y}^{\prime}
\end{array}\right)=\left(\begin{array}{cc}
\cos \alpha_{0} & -\operatorname{sen} \alpha_{0} \\
\operatorname{sen} \alpha_{0} & \cos \alpha_{0}
\end{array}\right) \times\left(\begin{array}{l}
w_{x} \\
w_{y}
\end{array}\right)=\left(\begin{array}{c}
w_{x} \cos \alpha_{0}-w_{y} \operatorname{sen} \alpha_{0} \\
w_{x} \operatorname{sen} \alpha_{0}+w_{y} \cos \alpha_{0}
\end{array}\right)
$$

Logo as coordenadas de $\overrightarrow{w^{\prime}}$ são:

$$
\begin{aligned}
& w_{x}^{\prime}=w_{x} \cos \alpha_{0}-w_{y} \operatorname{sen} \alpha_{0} \\
& w_{y}{ }^{\prime}=w_{x} \operatorname{sen} \alpha_{0}-w_{y} \cos \alpha_{0}
\end{aligned}
$$

$\mathrm{O}$ valor do ângulo $\beta$ deve ser tal que a resultante esteja sobre o eixo y. Para isso, a soma das abscissas dos vetores $\overrightarrow{v a_{1}}$ e $\vec{w}$ deve ser zero. Então: 


$$
\begin{aligned}
& v a_{1 x}=-w_{x} \\
& \left|\overrightarrow{v a_{1}}\right| \operatorname{sen} \beta=-w_{x}^{\prime} \\
& \beta=\operatorname{arcsen}\left(\frac{-w_{x}^{\prime}}{\left|\overrightarrow{v a_{1}}\right|}\right) \\
& \beta=\operatorname{arcsen}\left(\frac{-w_{x} \cos \alpha_{0}+w_{y} \operatorname{sen} \alpha_{0}}{\left|\overrightarrow{v a_{1}}\right|}\right)
\end{aligned}
$$

Como o módulo da velocidade aerodinâmica não é afetado pelo vento então $\left|\overrightarrow{v a_{1}}\right|=\left|\overrightarrow{v a_{0}}\right|=\left|\overrightarrow{v a_{1}}\right|$.

O vetor $\vec{w}$ não é dado diretamente. Partindo da definição de que a velocidade do vento influencia somente na velocidade em relação ao solo, $\overrightarrow{v a}=\overrightarrow{g s}-\vec{w}$, pode-se obter $\vec{w}$. Sejam:

$$
\begin{aligned}
& |\overrightarrow{v a}| \text { - módulo da velocidade aerodinâmica fornecida pelo velocímetro; } \\
& \alpha_{0} \text { - heading da aeronave fornecido pela bússola; } \\
& |\overrightarrow{g s}| \text { - módulo da velocidade em relação ao solo fornecido pelo receptor GPS; } \\
& \alpha_{g s} \text { - direção da aeronave fornecida pelo receptor GPS. }
\end{aligned}
$$

Logo

$$
\begin{aligned}
& \overrightarrow{v a}=\overrightarrow{g s}-\vec{w} \\
& \vec{w}=\overrightarrow{g s}-\overrightarrow{v a} \\
& \vec{w}=\underbrace{|\overrightarrow{v a}|\left(\operatorname{sen} \alpha_{0}, \cos \alpha_{0}\right)-|\overrightarrow{g s}|\left(\operatorname{sen} \alpha_{g s}, \cos \alpha_{g s}\right)}_{\text {transformaça de coordenadas }} \\
& \vec{w}=\left(|\overrightarrow{v a}| \operatorname{sen} \alpha_{0}-|\overrightarrow{g s}| \operatorname{sen} \alpha_{g s},|\overrightarrow{v a}| \cos \alpha_{0}-|\overrightarrow{g s}| \cos \alpha_{g s}\right)
\end{aligned}
$$

então 


$$
\beta=\operatorname{arcsen}\left(\frac{-w_{x} \cos \alpha_{0}+w_{y} \operatorname{sen} \alpha_{0}}{|\overrightarrow{v a}|}\right)
$$

onde

$$
w_{x}=|\overrightarrow{v a}| \operatorname{sen} \alpha_{0}-|\overrightarrow{g s}| \operatorname{sen} \alpha_{g s} \quad \text { e } \quad w_{y}=|\overrightarrow{v a}| \cos \alpha_{0}-|\overrightarrow{g s}| \cos \alpha_{g s}
$$

\subsection{Considerações Finais}

Neste capítulo foram apresentados os parâmetros operacionais e não operacionais de uma aeronave do projeto ARARA. Foi descrita também a utilização de estimativas dos parâmetros para se obter um melhor desempenho. Todas as manobras a serem realizadas pela aeronave foram definidas, juntamente com suas características, e classificadas de acordo com as situações de vôo.

Foram apresentadas as soluções desenvolvidas para um Sistema de Navegação, baseado em um receptor GPS. Dentre estas soluções estão a rota quadrilátera para o tratamento de exceções, o cálculo da distância necessária entre um par de waypoints para a realização de manobras ascendente, descendente e curva nivelada. Foram também apresentados o cálculo dos ângulos das curvas niveladas e uma síntese dos conjuntos de manobras básicas para diferentes situações de vôo.

Também foram descritos neste capítulo os tipos de vento que pode atingir uma aeronave em vôo e a solução encontrada para a correção da proa da aeronave quando esta é atingida por um vento de través.

No próximo capítulo são apresentadas as conclusões deste trabalho e sugestões para trabalhos futuros. 


\section{Capítulo 6}

\section{Conclusões}

\subsection{Considerações Iniciais}

Este trabalho está inserido dentro do projeto ARARA, que foi revisto juntamente com os conceitos básicos sobre UAVs, os equipamentos que os compõem e suas aplicações. Outros conceitos importantes para o desenvolvimento do projeto foram igualmente revistos incluindo sistemas de navegação e controle de vôo automático, o relacionamento entre estes dois sistemas, os tipos tradicionais de sistema de navegação e o sistema de navegação por GPS. Foram discutidos o funcionamento de um receptor GPS, suas vantagens e desvantagens e os sistemas de coordenadas geográficas utilizados por este receptor.

O sistema SiNaCoM, Sistema de Navegação e Controle de Missão, do projeto ARARA foi detalhadamente analisado, projetado e especificado. O SiNaCoM foi dividido em dois módulos: o Planejador de Missão e o Sistema de Navegação. Em todo o processo de desenvolvimento foram utilizadas ferramentas de análise estruturada de sistemas para melhor documentação e facilidade nas futuras manutenções que possam ser necessárias. O módulo Sistema de Navegação também foi especificado utilizando-se statecharts, uma vez que se trata de um sistema de tempo real com vários processos operando concorrentemente. Os detalhes da implementação do módulo Planejador de Missão foram descritos. O módulo Sistema de Navegação foi totalmente especificado até o nível de algoritmo.

Neste capítulo são enumeradas, na seção 6.1, as principais contribuições deste trabalho. $\mathrm{Na}$ seção 6.2 são feitas as conclusões finais e na seção 6.3, apresentadas algumas sugestões para a sua continuidade. 


\subsection{Contribuições do Trabalho}

O desenvolvimento deste trabalho resultou nas seguintes contribuições:

+ Estudo das necessidades de planejamento e controle de missão para aeronaves da fase III do projeto ARARA em função do estado tecnológico de desenvolvimento dos seus componentes principais;

$\rightarrow$ Proposição de uma abordagem para dividir as funções normalmente encontradas monoliticamente em pilotos automáticos convencionais em dois grupos: navegação e aumento de estabilidade.

† Definição de um conjunto de manobras básicas, para comunicação entre o módulo responsável pela navegação e o módulo responsável pelo aumento de estabilidade, com elevado nível de independência em relação aos parâmetros de vôo da aeronave;

$\rightarrow$ Desenvolvimento de um sistema com interface gráfica para o planejamento de missões que permite a utilização de mapas digitais de uma área, de fotografias aéreas ou de esboços acrescidos de marcos para traçar uma rota e definir tarefas em cada waypoint desta rota.

† Projeto e especificação de um sistema de navegação baseado em um receptor GPS e desenvolvimento de um algoritmo de controle de vôo, baseado no conjunto de manobras básicas definidos.

\subsection{Conclusões Finais}

A análise de requisitos e a especificação do módulo Planejador de Missão culminaram no seu desenvolvimento. Este módulo, por ser independente do módulo Sistema de Navegação e do hardware da aeronave, foi desenvolvido e testado. Algumas funções acessórias tiveram sua implementação postergada para minimizar o tempo de desenvolvimento.

O módulo Sistema de Navegação foi analisado e especificado. A partir desta especificação, foi apresentada uma solução de manobras para que a aeronave percorra toda a 
trajetória programada pelo usuário, realizado as tarefas. A solução está representada na forma de um algoritmo nos apêndices $\mathrm{B}$ e $\mathrm{C}$ e todos os cálculos utilizados na sua execução estão descritos no capítulo 6 . $\mathrm{O}$ algoritmo não foi implementado por estar intimamente relacionado com o hardware da aeronave que ainda não foi definido.

A literatura encontrada não cita nenhum sistema de navegação independente do piloto automático. Foi encontrada uma certa dificuldade na definição da interface entre estes dois sistemas e na divisão de suas funções. Foi também encontrada dificuldade na definição das manobras possíveis de serem realizadas por uma aeronave.

\subsection{Sugestões para Trabalhos Futuros}

Apesar deste trabalho ter envolvido a implementação de alguns subsistemas, outros tiveram a sua implementação adiada, conforme descrito no item anterior. Vários trabalhos futuros podem ser feitos em continuidade ao até aqui desenvolvido. Enquanto alguns são adequados para programas de mestrado, outros apresentam complexidade reduzida e devem ser desenvolvidos dentro de programas de iniciação científica. Entres esses trabalhos pode-se citar:

$\rightarrow$ Desenvolvimento de um sistema para desenhar e delimitar mapas a partir de pontos coletados por um receptor GPS. O usuário carrega waypoints no receptor GPS, percorrendo a aérea que se deseja delimitar, e conecta o receptor GPS ao computador. O sistema, automaticamente, coleta os waypoints e delimita a região correspondente na tela. O usuário pode, então, inserir fotografias e desenhos no mapa do tipo montanhas, rios e prédios, correspondentes à região verdadeira;

Desenvolvimento de uma interface para planejar missões, a partir de fotografias aéreas, e de uma função de correção de distorções, que aplicada à fotografia, remova as distorções provocadas pela inclinação da aeronave no momento da coleta das fotografias, pela projeção cônica característica da fotografia e aquelas provocadas pela qualidade das lentes utilizadas;

† Desenvolvimento de uma interface gráfica para a reconstrução da missão a partir do $\log$ de vôo armazenado durante a execução da missão. Nesta interface, o usuário 
poderá verificar todas as ações realizadas pela aeronave durante a missão;

$\rightarrow$ Desenvolvimento de uma interface gráfica para permitir a mudança de rotas e tarefas no plano de missão, em tempo real. Os waypoints que já foram alcançados pela aeronave são marcados na tela do computador e a mudança de rota pode ser aplicada aos waypints ainda não marcados. O novo trecho de rota e as novas tarefas podem ser transmitidos e atualizados na aeronave através de um canal de transmissão de dados que está sendo atualmente desenvolvido em outro trabalho de mestrado.

† Implementação do algoritmo de navegação especificado no capítulo 6 e apêndices $\mathrm{B}$ e $\mathrm{C}$;

+ Extensão do conjunto de manobras definido para a aeronave do projeto ARARA. Existem diversas manobras que podem ser inseridas no Sistema de Navegação tais como vôos em curva ascendente, em curva descendente, em forma de espiral e " $\mathrm{S}$ ". Essas novas manobras devem permitir que a aeronave siga as rotas de forma otimizada. 


\section{Referências Bibliográficas}

[HOL99] HOLLAND, Greg. Aerosonde: Robotic Aircraft. Disponível em: <http://www. aerosonde.com>. Acesso em: 01 abr. 2000.

[AGG00] AgGPS 114 Operation Manual. Disponível em: <http://www.trimble.com>. Acesso em: 04 abr. 2001.

[ALL96] ALLERTON, D. J. Avionics, systems design and simulation. Aeronautical Journal, v. 100 , n. 1000 , p. 439-448, Dez. 1996.

[AXE99] AXEL, Adriano. Triângulo de Vento. Disponível em: <http://www.airandinas.com/ triangulo_vento.html>. Acesso em: 25 maio 2001.

[BENO0a] BENSON, Tom. Relative Velocities. Disponível em: <http://www.grc.nasa.gov /WWW/K-12/airplane/move.html>. Acesso em: 13 jan. 2001.

[BENOOb] BENSON, Tom. Cross Winds. Disponível em: <http://www.grc.nasa.gov/WWW/K2/airplane/move3.html>. Acesso em: 13 fev. 2001.

[BOR99] BORENSTEIN, Johann. Navigation Mobile Robots: Sensors and Techniques. Disponível em: <http://www-personal.engin.umich.edu/ johannb>. Acesso em: 17 fev. 2000 .

[BOU87] BOULOS, Paulo. Geometria Analítica: Um Tratamento Vetorial. São Paulo: Makron Books, 1987. 382 p.

[BOY99] BOYLE, David P.; CHAMITOFF, Gregory E. Autonomous maneuver tracking for self-pilot vehicles. Journal of Guidance, Control and Dynamics, v. 22, n. 1, p. 5867, Jan./Feb. 1999.

[BOW01] BOWERS, J. Latitude and Longitude, The Geographic Coordinate System. Disponível em: <http://www.langara.bc.ca/geography/infofold/jb2210/Notes/Earth_to _map/latitude_longitude/notes.htm>. Acesso em: 08 mar. 2001. 
[BRI99a] ENCICLOPÉDIA BRITÂNICA: Navigation. Disponível em: <http://www. britannica.com/bcom/eb/article>. Acesso em: 23 fev. 2000.

[BRI99b] ENCICLOPÉDIA BRITÂNICA: Compass. Disponível em: <http://www.gisca. adelaide.edu.au/ bbryan/lectures/geodesy/>. Acesso em: 23 fev. 2000.

[BRY99] BRYAN, B. Geodesy, Projections, and Coordinate Systems. Disponível em: <http://www.britannica.com/bcom/eb/article>. Acesso em: 21 fev. 2001.

[BRY94] BRYSON, Arthur Earl. Control of Spacecraft and Aircraft. New Jersey: Princeton University Press, 1994. 378 p.

[CANO0] CANTÚ, Marcos. Dominando o Delphi 5. São Paulo: Makron Books, 2000. 860 p.

[CAR98] CARNES, John. Using the UTM map coordinate system. Disponível em: <http://www. maptools.com/UsingUTM/index.html>. Acesso em: 20 fev. 2001.

[CAR76] CARVALHO, João Pitombeira. Geometria Analítica e Álgebra Linear: um tratamento moderno. Rio de Janeiro: Ao Livro Técnico S.A, 1976. 166 p.

[DAN95] DANA, Peter. Coordinate Systems Overview. Disponível em: <http://www. colorado.edu/geography/gcraft/notes/coordsys/coordsys_f.html>. Acesso em: 21 fev. 2001.

[DOT97] DOTTORI, Marcio. GPS Manual Prático. São Paulo: Fittipaldi, 1997. 64 p.

[ELF98] ELFES, Alberto; BUENO, Samuel Siqueira; BERGERMAN, Marcel. Project AURORA: Development of an Autonomous Unmanned Remote Monitoring Robotics Airship. Journal of the Brazilian Computer, v.4, n. 3, p. 170-78, Abr. 1998.

[GOB01] Global Majic Software. Component Moving Map. Disponível em: <http://www. globalmajic.com>. Acesso em: 17 ag. 2000.

[HAR87] HAREL, David. Statecharts: A Visual Formalism for Complex Systems. Science of Computer Programming, v 8, p. 231-275, Jul. 1987.

[HOL31] HOLLAND, H. Aviation. $1^{\mathrm{a}}$ ed. New York: McGraw Hill, 1931. 
[INA95] INAMIYA, K.; SAKATA, K. A. Conceptual study of a navigation and communication satellite system. IEICE Transactions on communications, n. 7, p. 1065-1074, Jul. 1995.

[KAY69] KAYTON, Myron. Avionics Navigation Systems. New York: John Wiley \& Sons, 1969. $666 \mathrm{p}$.

[KER70] KERMODE, A. Flight without Formulas. $5^{\text {a }}$ ed. England: Longman, 1970.

[KHE99] KHELIF D.; BURNS, S. P.; FRIECHE, C. A. Improved wind measurements on research aircraft. Journal of Atmospheric and Oceanic Technology, v. 16, n. 7, p. 860-875, Jul. 1999.

[LET98] LETHAM, Lawrence. GPS Made Easy. $2^{\text {a }}$ ed. Calgary: Rocky Mountain Books, 1998.

[LOB96] LOBO, José Francisco. Noções de Física Aplicada a Vôo Simulado. Disponível em: <http://www.fsa.com.br>. Acesso em: 11 jan. 2001.

[LOB99] LOBO, José Francisco. Correção de Deriva para Vôo Simulado. Disponível em: <http://www.fsa.com.br>. Acesso em: 11 jan. 2001.

[LOG92] LOGSDON, Tom. The Navstar Global Positioning System. New York: Van Nostrand Reinhold, 1992. 256 p.

[MED72] MEDEIROS, João Dutra. Manual de Navegação Aérea. Rio de Janeiro: Editora Técnica de Aviação, 1972.

[MIL00] MILBERT, Dennis. Comparison of Positions With and Without Selective Availability. Disponível em: <http://www.ngs.noaa.gov/FGCS/info/sans_AS/ compare/ERLA.html >. Acesso em: 11 jan. 2001.

[MOL98] CARNEGIE MELLON ROBOTICS INSTITUTE. Autonomous Helicopter Project. Disponível em: <http://www.sc.cmu.edu/afs/cs/project/chopper/www/goals.html>. Acesso em: 05 fev. 2000.

[NEL98] NELSON, Robert. Flight Stability and Automatic Control. $2^{\mathrm{a}}$ ed. Singapore: McGraw Hill, 1998. 284 p. 
[NER00] NERIS, Luciano de Oliveira. 2000. 52 f.. Um Controlador de Vôo para o Projeto ARARA. Monografia de exame de qualificação - Instituto de Ciências Matemáticas e de Computação, Universidade de São Paulo, São Carlos.

[ONC99] M12 Oncore: GPS Module. Disponível em: <http:// www.oncore.motorola.com>. Acesso em: 07 jan. 2000.

[PAL91] PALLETT, E. H. J. Aircraft Instruments. $2^{\text {a }}$ ed. London: Longman Scientific \& Technical, 1991. 414 p.

[PAL96] PALLETT, E. H. J. Automatic Flight Control. $2^{\text {a }}$ ed. London: Blackwell Science, 1996. $323 \mathrm{p}$.

[PAZ00] PAZ, M. P. Sistema de Posicionamento Global (GPS) e suas aplicações. Disponível em: <http://www.pcs.usp.br/ pcs713/Aula06/index.htm>. Acesso em: 21 jan. 2001.

[PRE95] PRESSMAN, Roger S. Engenharia de Software. São Paulo: Makron Books, 1995. $1056 \mathrm{p}$.

[PRO96] PROCHASKA, Edgard. Aprendendo a Voar - Manual Básico para Treinamento Prático de Piloto. $3^{\mathrm{a}}$ ed. São Paulo: Edições e Artes Gráficas LTDA, 1996. 249 p.

[REI96] REIS, Omar. Fundamentos da Navegação Astronômica. Disponível em: <http://www.tecepe.com.br/nav/nav_c11.htm>. Acesso em: 07 abr. 2001.

[RIB00] RIBEIRO, Rômulo Eugênio. STT: Um Sistema de Telemetria e Telecomando de Aeronaves do Projeto ARARA. 2000. 137 f.. Dissertação (Mestrado em Ciência da Computação) - Instituto de Ciências Matemáticas e de Computação, Universidade de São Paulo, São Carlos.

[SOA99] SOARES, Paulo Marcelo. Curso de Vôo por Instrumentos nos Simuladores. Disponível em: <http://www.fsa.com.br>. Acesso em: 01 abr. 2000.

[SIU91] SIURU, B. Planes Without Pilots Advances in Unmanned Flight. $2^{\mathrm{a}}$ ed. USA: McGraw Hill, 1991. 
[SMI93] SMITH, S. G. Automatic navigation in the air and at sea. Aeronautical Journal, v. 97, n. 966, p. 183-194, Jun./Jul. 1993.

[SOU99] SOUZA, Nilda Pessoa. Uso de Aeronaves Rádio Controladas para Aplicação na Agricultura: O Protocolo de Enlace de Dados. 1999. 124f.. Dissertação (Mestrado em Ciência da Computação) - Instituto de Ciências Matemáticas e de Computação, Universidade de São Paulo, São Carlos.

[STE87] STEINBRUCH, Alfredo. Geometria Analítica. $2^{a}$ ed. São Paulo: McGraw Hill, 1987. $292 \mathrm{p}$.

[STE92] STEVENS, Brian. Aircraft Control and Simulation. New York: John Wiley \& Sons, $1992.617 \mathrm{p}$.

[SUG99] SUGETA, Tatiana; MALDONADO, José Carlos. Introdução a Statecharts: Conceitos Básicos, Teste e Validação, Extensões e Ferramentas de Apoio. Notas Didáticas do ICMC/USP, São Carlos, 1999. 88 p.

[SZC00] SZCZERBA, R. J.; GALKOWSKI, P.; GLICKSTEIN, I. S. Robust Algorithm for Real-Time Route Planning. IEEE Transactions on Aerospace and Electronic Systems, v 36, n. 3, p. 869-878, Jul. 2000.

[THO94] THOMPSON, L. A; BIL, C. The design and flight trails of a multi-propose autonomous flight vehicle system. In: CONGRESS OF THE INTERNATIONAL CONCIL FOR THE AERONAUTICAL SCIENCES, 19., 1994, Los Angeles. Proceedings of ICAS 94. p. 18-23.

[UAV00] UAV Research Facility. Disponível em: <http://controls.ae.gatech.edu/labs/uavrf/>. Acesso em: 01 abr. 2000.

[VAL96] VALENTINIS, Francis; BIL, Cees; RISEBOROUGH, Paul. Development and trials of an autonomous flight control system for UAVs. In: CONGRESS OF THE INTERNATIONAL CONCIL FOR THE AERONAUTICAL SCIENCES, 20., 1996, Los Angeles. Proceedings of ICAS 96. p. 1294-1304. 
[YOU92] YOURDON, Eduard. Análise Estruturada Moderna. $3^{\mathrm{a}}$ ed. Rio de Janeiro: Campus, $1992.836 \mathrm{p}$.

[WAN96] WANG, Y. S.; LI, X. P.; HUANG, Y. Navigation system of pilotless aircraft via GPS. IEEE Aerospace and Electronic Systems Magazine, v. 11, n. 8, p. 16-20, Ag. 1996. 


\section{Apêndice $A$}

\section{Sentenças NMEA}

Tabela B.1 - Sentença GGA: Dados de fixação de posição.

\begin{tabular}{|c|c|}
\hline Campo & Deseriçẵo \\
\hline 1 & UTC da fixação da posição em HHMMSS,SS \\
\hline 2 & Latitude em DD MM,MMMM (0-7 casas decimais) \\
\hline 3 & Direçăo de latitude (N ou $\mathbf{S}$ ) \\
\hline 4 & Longitude em DD MM,MMMM (0-7 casas decimais) \\
\hline 5 & Direção de longitude (E ou W) \\
\hline 6 & Indicador de qualidade do GPS: \\
\hline & 0: fixação de posição não válida \\
\hline & 1: fixaçāo de posição com GPS \\
\hline & 2: fixação de posição com DGPS \\
\hline 7 & Número de satélites (SVs) em uso, 00-12 \\
\hline 8 & HDOP - Horizontal Dilution of Precision \\
\hline 9 & Altura da antena \\
\hline 10 & Altitude em metros \\
\hline 11 & $\begin{array}{l}\text { Separação geoidal (distância perpendicular entre o geóide e a elipse de referência } \\
\text { da Terra) }\end{array}$ \\
\hline 12 & Caracter 'M'indica que o valor da separação geoidal está em metros \\
\hline 13 & $\begin{array}{l}\text { Tempo, em segundos, da última atualização dos dados realizada por uma estaçăo } \\
\text { base do sistema DGPS. Campo vazio se DGPS não é usado }\end{array}$ \\
\hline 14 & ID da estação base do sistema DGPS, $0000-1023$ \\
\hline
\end{tabular}


Tabela B.2 - Sentença GLL: Dados de posição.

\begin{tabular}{l|l}
\hline Campq & Desertição \\
\hline 1 & Latitude em DD MM,MMMM (0-7 casas decimais) \\
2 & Direção de latitude (N ou S) \\
3 & Longitude em DD MM,MMMM (0-7 casas decimais) \\
4 & Direção de longitude (E ou W) \\
5 & UTC da posição em HHMMSS.SS \\
6 & Caracter 'A' indica que o dado é válido \\
7 & Vide sentença RMC, linha 12 \\
\hline
\end{tabular}

Tabela B.3 - Sentença GSA: DOP, GPS e satélites ativos.

\begin{tabular}{|c|c|}
\hline Campo & Deseriça \\
\hline \multirow[t]{3}{*}{1} & Modo: \\
\hline & M: manual, forçado a operar em 2D ou 3D \\
\hline & A: automático, 2D/3D \\
\hline \multirow[t]{4}{*}{2} & Modo: \\
\hline & 1: fixaçāo não disponível \\
\hline & 2: $2 \mathrm{D}$ (latitude/longitude) \\
\hline & 3: 3D (latitude/longitude/altitude) \\
\hline $3-14$ & IDs dos SVs usados na fixaçāo da posição \\
\hline 15 & PDOP - Position Dilution of Precision \\
\hline 16 & HDOP - Horizontal Dilution of Precision \\
\hline 17 & VDOP - Vertical Dilution of Precision \\
\hline
\end{tabular}


Tabela B.4 - Sentença GSV: Informaçōes sobre os satélites visíveis.

\begin{tabular}{|c|c|}
\hline Campo & Descriçĩo \\
\hline 1 & Número total de sentenças deste tipo no ciclo atual \\
\hline 2 & Número da sentença \\
\hline 3 & Número total de SVs visíveis \\
\hline 4 & $\begin{array}{l}\text { Número PRN do SV (Pseudo Random Number - cada satélite do sistema GPS } \\
\text { possui um número PRN único) }\end{array}$ \\
\hline 5 & Elevação em graus, máximo de 90, 5 \\
\hline 6 & Azimute, em graus a partir do norte verdadeiro, 000,5 ate 359,5 \\
\hline 7 & $\begin{array}{l}\text { SNR, 00-99 dB (Signal to Noise Ratio - também chamado de nível de sinal, } \\
\text { unidade arbitrária para descrever a potência do sinal de um satélite) }\end{array}$ \\
\hline $8-11$ & Informação sobre o segundo SV, mesmo formato dos campos 4-7 \\
\hline $12-15$ & Informação sobre o terceiro SV, mesmo formato dos campos 4-7 \\
\hline $8-11$ & Informação sobre o quarto SV, mesmo formato dos campos 4-7 \\
\hline
\end{tabular}


Tabela B.5 - Sentença RMC: Especificação mínima de dados do GPS recomendada.

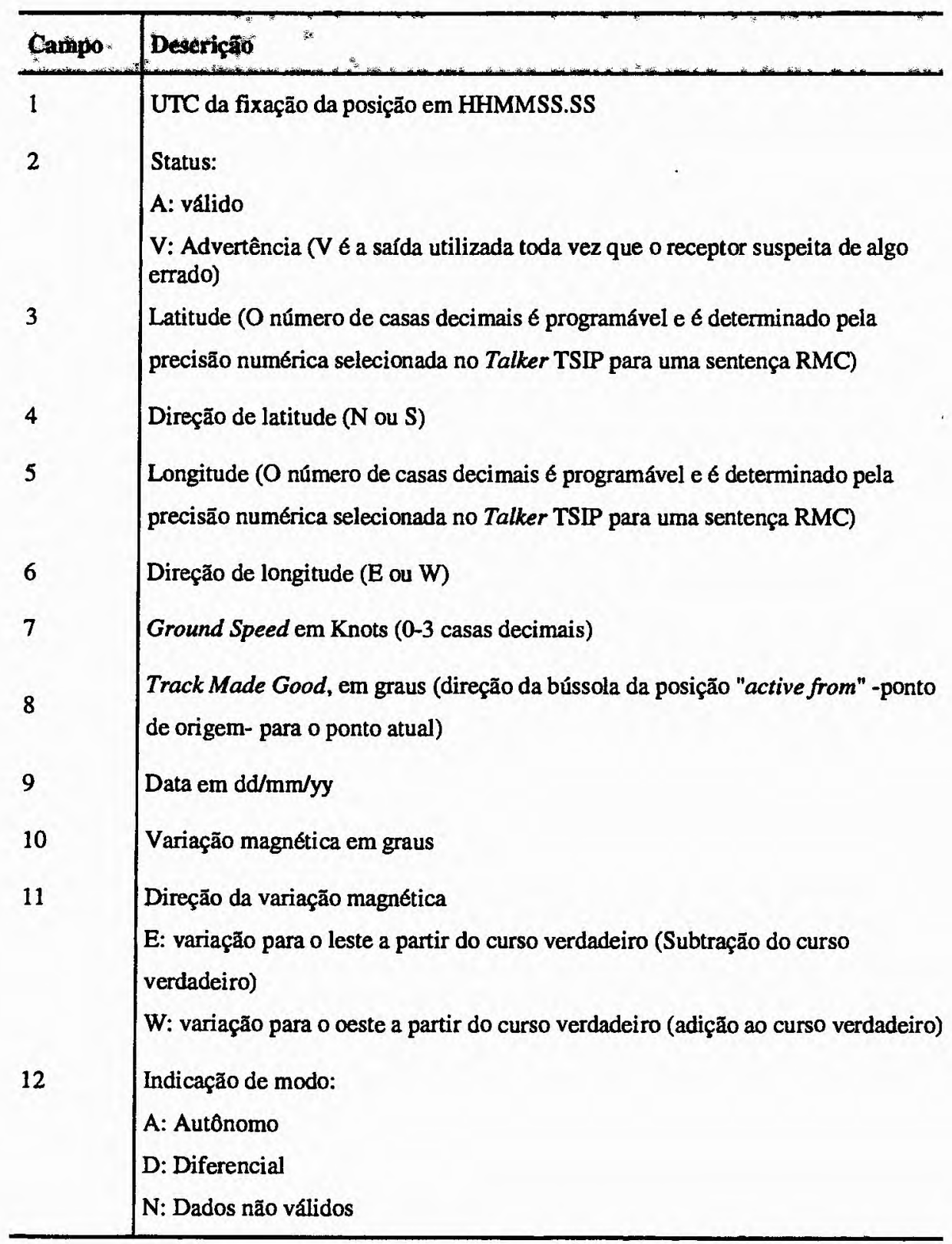


Tabela B.6 - Sentença VTG: Curso e Ground Speed.

\begin{tabular}{|c|c|}
\hline Campo & Descriço \\
\hline 1 & $\begin{array}{l}\text { Track made good (direção da bússola da posição "active from" -ponto de origem- } \\
\text { para o ponto atual) }\end{array}$ \\
\hline 2 & Caracter ' $T$ ' indica que Track made good é relativo ao norte verdadeiro \\
\hline 3 & Não utilizado \\
\hline 4 & Não utilizado \\
\hline 5 & Ground Speed em knots (0-3 casas decimais) \\
\hline 6 & Caracter ' $N$ ' indica que o Ground Speed é em knots \\
\hline 7 & Ground Speed em Km/h (0-3 casas decimais) \\
\hline 8 & Caracter ' $\mathrm{K}$ ' indica que o Ground Speed $6 \mathrm{em} \mathrm{Km} / \mathrm{h}$ \\
\hline
\end{tabular}

Tabela B.7 - Sentença ZDA: Hora e data.

\begin{tabular}{l|l}
\hline Campo & Descriçä́ \\
\hline 1 & Hora UTC \\
2 & Dia \\
3 & Mês \\
4 & Offset da hora local \\
5 & Offset dos minutos da hora local \\
\hline
\end{tabular}




\section{Apêndice B}

\section{Conjunto de Manobras}

As tabelas a seguir mostram as manobras a serem realizadas para os seguintes intervalos de $\theta$ : $0^{\circ} \leq \theta<90^{\circ}, 90^{\circ} \leq \theta<180^{\circ}$ e $\theta$ igual a $180^{\circ}$. As manobras para $\theta$ nos intervalos $270^{\circ}<\theta \leq 360^{\circ}$ e $180^{\circ}<\theta \leq 270^{\circ}$ são análogas para os intervalos $0^{\circ} \leq \theta<90^{\circ}$ e $90^{\circ}$ $\leq \theta<180^{\circ}$, respectivamente, diferindo apenas nas direções e nos ângulos das curvas. Abaixo, segue a legenda para a interpretação das tabelas.

Legenda:

- vôonivelado $\boldsymbol{f}$ curva nivelada $\boldsymbol{\Delta}$ vôo descendente $\boldsymbol{\Delta}$ vôo ascendente 
Tabela A.1 - Conjunto de soluções para $0^{\circ} \leq \theta<90^{\circ}$ e análogo para $270^{\circ}<\theta \leq 360^{\circ}$.

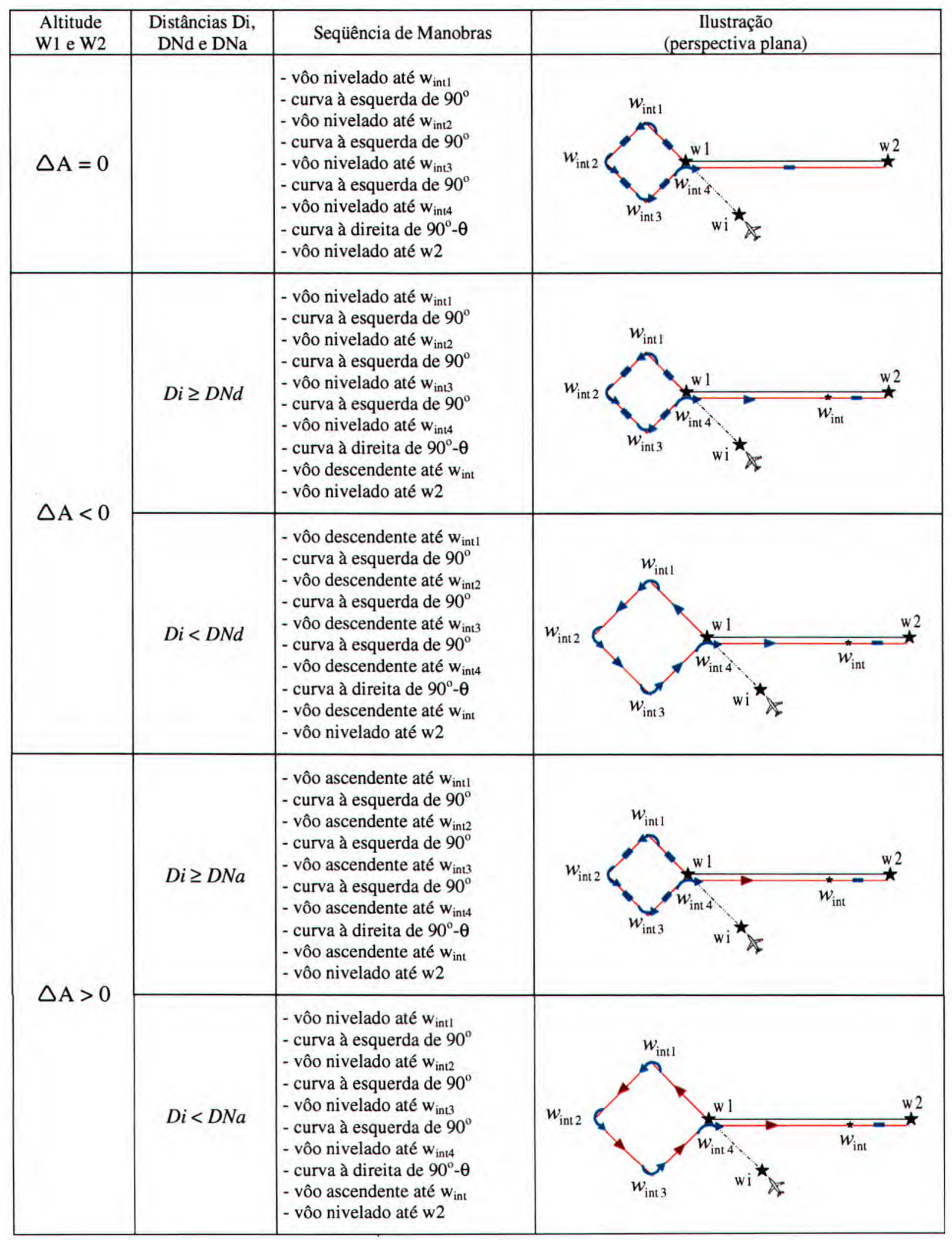


Tabela A.2 - Conjunto de soluções para $90^{\circ} \leq \theta<180^{\circ}$ e análogo para $180^{\circ}<\theta \leq 270^{\circ}$.

\begin{tabular}{|c|c|c|c|c|}
\hline $\begin{array}{c}\text { Altitude } \\
\text { W1 e W2 }\end{array}$ & \multicolumn{2}{|c|}{ Distâncias Di, DNd e DNa } & Sequiência de Manobras & Ilustração (perspectiva plana) \\
\hline \multirow[b]{2}{*}{$\Delta \mathrm{A}=0$} & \multicolumn{2}{|c|}{$D \geq D N c$} & $\begin{array}{l}\text { - curva à direita de } \beta^{\circ} \\
\text { - curva à esquerda de } \alpha^{\circ} \\
\text { - vôo nivelado até w2 }\end{array}$ & $\Rightarrow$ \\
\hline & \multicolumn{2}{|c|}{$D<D N c$} & $\begin{array}{l}\text { - vôo nivelado até } \mathrm{w}_{\text {int1 }} \\
\text { - curva à esquerda de } 90^{\circ} \\
\text { - vôo nivelado até } \mathrm{w}_{\text {int2 }} \\
\text { - curva à esquerda de } 90^{\circ} \\
\text { - vôo nivelado até } \mathrm{w}_{\text {int3 }} \\
\text { - curva à esquerda de } 90^{\circ} \\
\text { - vôo nivelado até } \mathrm{w}_{\text {int4 }} \\
\text { - curva à esquerda de } \theta-90^{\circ} \\
\text { - vôo nivelado até } \mathrm{w} 2\end{array}$ & $\begin{array}{c}\star \\
\text { w2 }\end{array}$ \\
\hline \multirow{3}{*}{$\Delta \mathrm{A}<0$} & \multicolumn{2}{|c|}{$D i \geq D N c+D N d$} & $\begin{array}{l}\text { - curva à direita de } \beta^{\circ} \\
\text { - curva à esquerda de } \alpha^{\circ} \\
\text { - vôo descendente até } w_{\text {int }} \\
\text { - vôo nivelado até w2 }\end{array}$ & 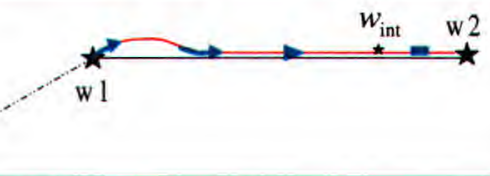 \\
\hline & \multirow{2}{*}{$\begin{array}{l}D i< \\
D N c+D N d\end{array}$} & $D i \geq D N d$ & $\begin{array}{l}\text { - vôo nivelado até } \mathrm{w}_{\mathrm{int1}} \\
\text { - curva à esquerda de } 90^{\circ} \\
\text { - vôo nivelado até } \mathrm{w}_{\mathrm{int2}} \\
\text { - curva à esquerda de } 90^{\circ} \\
\text { - vôo nivelado até } \mathrm{w}_{\text {int3 }} \\
\text { - curva à esquerda de } 90^{\circ} \\
\text { - vôo nivelado até } \mathrm{w}_{\text {int4 }} \\
\text { - curva à esquerda de } \theta-90^{\circ} \\
\text { - vôo descendente até } \mathrm{w}_{\text {int }} \\
\text { - vôo nivelado até } \mathrm{w} 2\end{array}$ & $\underset{w_{\text {int }}}{\star} \underset{\text { w2 }}{\star}$ \\
\hline & & $D i<D N d$ & $\begin{array}{l}\text { - vôo descendente até } w_{\text {int1 }} \\
\text { - curva à esquerda de } 90^{\circ} \\
\text { - vôo descendente até } w_{\text {int2 }} \\
\text { - curva à esquerda de } 90^{\circ} \\
\text { - vôo descendente até } w_{\text {int3 }} \\
\text { - curva à esquerda de } 90^{\circ} \\
\text { - vôo descendente até } w_{\text {int4 }} \\
\text { - curva à esquerda de } \theta-90^{\circ} \\
\text { - vôo descendente até } w_{\text {int }} \\
\text { - vôo nivelado até w2 }\end{array}$ & $\underset{w_{\text {int }}}{=}$ \\
\hline$\Delta \mathrm{A}>0$ & \multicolumn{2}{|c|}{$D i \geq D N c+D N a$} & $\begin{array}{l}\text { - curva à direita de } \beta^{\circ} \\
\text { - curva à esquerda de } \alpha^{\circ} \\
\text { - vôo ascendente até } w_{\text {int }} \\
\text { - vôo nivelado até w2 }\end{array}$ & $\stackrel{w_{\text {int }}}{{ }_{\star}} \stackrel{w 2}{\star}$ \\
\hline
\end{tabular}




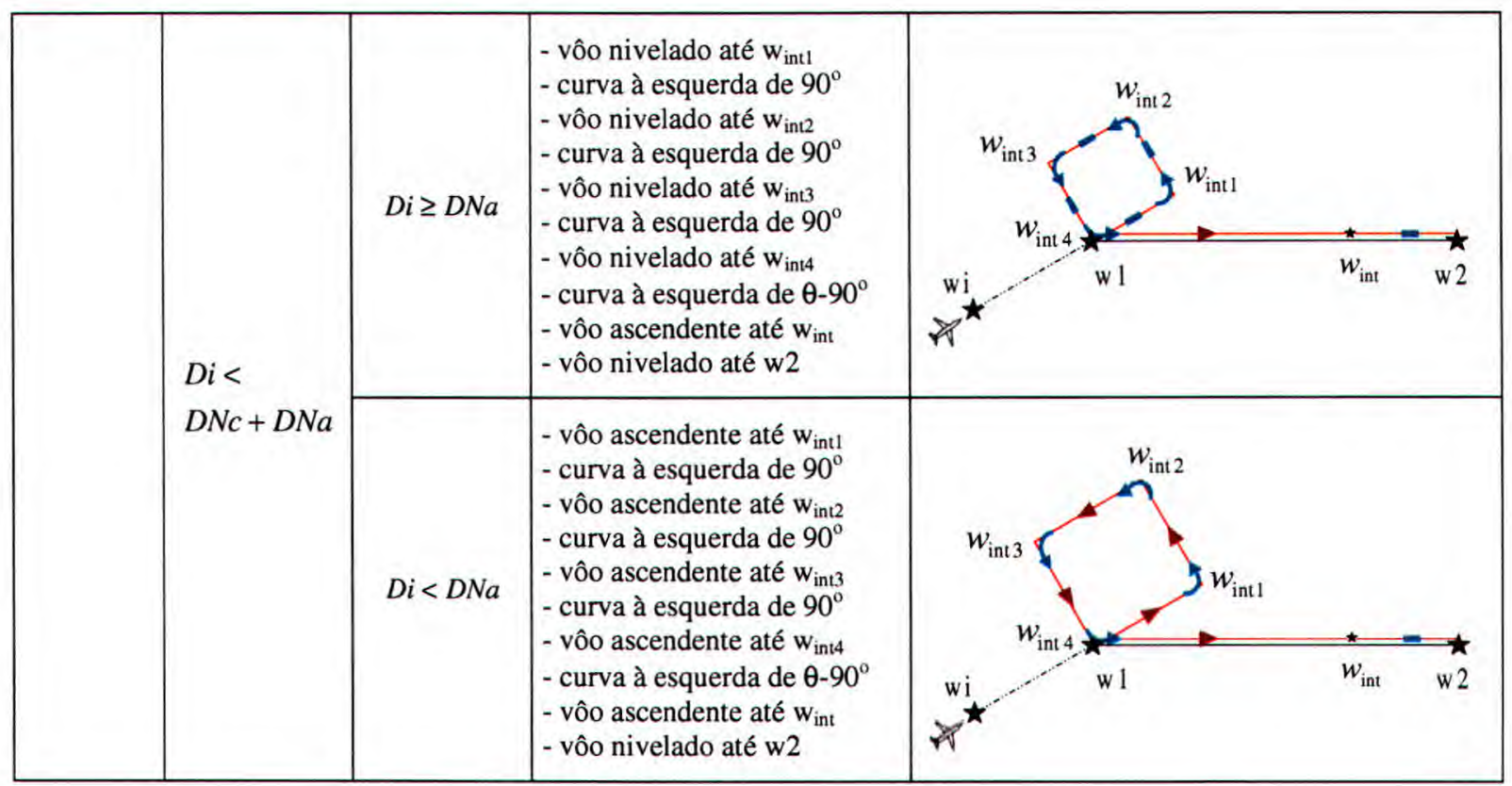


Tabela A.3 - Conjunto de soluções para $\theta=180^{\circ}$.

\begin{tabular}{|c|c|c|c|}
\hline $\begin{array}{c}\text { Altitude } \\
\text { W1 e W2 }\end{array}$ & $\begin{array}{c}\text { Distâncias Di, } \\
\text { DNd e DNa }\end{array}$ & Sequiência de Manobras & Ilustração (perspectiva plana) \\
\hline$\Delta \mathrm{A}=0$ & 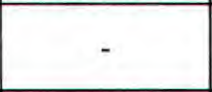 & - vôo nivelado até w2 & $\underset{w 1}{\star} \underset{w 1}{\star}$ \\
\hline & $D i \geq D N d$ & $\begin{array}{l}\text { - vôo descendente até } w_{\text {int }} \\
\text { - vôo nivelado até w2 }\end{array}$ & $+\frac{1}{w i} \underset{w 1}{\star} \underset{w_{\text {int }}}{\star}=\underset{w 2}{\star}$ \\
\hline$\Delta \mathrm{A}<0$ & $D i<D N d$ & $\begin{array}{l}\text { - curva à esquerda de } 90^{\circ} \\
\text { - vôo descendente até } \mathrm{w}_{\mathrm{int} 1} \\
\text { - curva à esquerda de } 90^{\circ} \\
\text { - vôo descendente até } \mathrm{w}_{\mathrm{int} 2} \\
\text { - curva à esquerda de } 90^{\circ} \\
\text { - vôo descendente até } \mathrm{w}_{\mathrm{int} 3} \\
\text { - curva à esquerda de } 90^{\circ} \\
\text { - vôo descendente até } \mathrm{w}_{\mathrm{int}} \\
\text { - vôo nivelado até w2 }\end{array}$ & $\underset{w i}{w_{\text {int } 3}}$ \\
\hline \multirow[b]{2}{*}{$\Delta \mathrm{A}>0$} & $D i \geq D N a$ & $\begin{array}{l}\text { - vôo ascendente até } w_{\text {int }} \\
\text { - vôo nivelado até w2 }\end{array}$ & $\underset{w i}{\star} \underset{w_{\text {int }}}{\star} \underset{\text { w2 }}{\star}$ \\
\hline & $D i<D N a$ & $\begin{array}{l}\text { - curva à esquerda de } 90^{\circ} \\
\text { - vôo ascendente até } \mathrm{w}_{\text {int1 }} \\
\text { - curva à esquerda de } 90^{\circ} \\
\text { - vôo ascendente até } \mathrm{w}_{\mathrm{int2}} \\
\text { - curva à esquerda de } 90^{\circ} \\
\text { - vôo ascendente até } \mathrm{w}_{\mathrm{int} 3} \\
\text { - curva à esquerda de } 90^{\circ} \\
\text { - vôo ascendente até } \mathrm{w}_{\mathrm{int}} \\
\text { - vôo nivelado até w2 }\end{array}$ & $\underset{w i}{w_{\text {int } 3}}$ \\
\hline
\end{tabular}




\section{Apêndice C}

\section{Algoritmo do Sistema de Navegação}

Foram definidas as seguintes bases de dados:

- Tabela Plano_de_Vôo: tabela fornecida pelo módulo Planejador de Missão e compartilhada por todas as funções do módulo Sistema de Navegação.

- Tabela Sensores: tabela que armazena dados válidos dos sensores e compartilhada pelas funções Monitora_Rota e Coleta_Dados_Sensores.

- Tabela Parâmetros: tabela que armazena os parâmetros operacionais e não operacionais e suas estimativas. 
(Programa Principal)

INICIO

Iniciar os processos Coletar_Dado_SensorX;

Iniciar o processo Enviar_Manobra_Piloto_Automático

ENQUANTO NĀO fim da tabela Plano_de_Vôo E Eensores em operação E rede operacional

Waypoint origem $\leftarrow$ registro atual da tabela Plano_de_Vôo

Waypoint destino $\leftarrow$ próximo registro ao registro atual da tabela Plano_de_Vôo

REPITA

Lista_Manobras $\leftarrow$ Decompor_Rota (waypoint de origem, waypoint de destino);

REPITA

Enviar_Manobra (item da lista Lista_Manobras)

Monitorar_Rota (item da lista Lista_Manobras);

ATÉ QUE fim de Lista_Manobras OU desvio de curso

SE desvio de curso

ENTÃO Waypoint origem $\leftarrow$ posição atual da aeronave

ATÉ QUE precisão do waypoint destino seja alcançada OU número de tentativas ultrapassado

Ir para próximo registro da tabela Plano_de_Vôo

Controlar_Execução_Tarefas (posição atual da aeronave)

\section{FIM ENQUANTO}

SE rede não operacional ou sensor defeituoso

ENTÃO Enviar comando para abortar missāo

SENĀO Enviar comando para finalizar missão

FIM 
(Decompõe o trecho de rota entre w1 e w2 em um conjunto de manobras) DECOMPOR_ROTA

\section{INíCIO}

Ler heading, h, e posição, wi, atuais da aeronave da tabela de Sensores;

Ler as coordenadas, wl e w2, do próximo par de waypoints da tab. Plano_de_Vôo;

Ler as altitudes, A1 e A2, do próximo par de waypoints da tab. Plano_de_Vôo;

$\theta \leftarrow$ Calcular_Ângulo_Chegada $(\mathrm{h}, \mathrm{wi}, \mathrm{w} 1, \mathrm{w} 2)$;

$\mathrm{D} \leftarrow$ Calcular_Distância_entre_Waypoints (w1, w2); (pág. 95)

Di $\leftarrow$ D - Dnv

$\triangle \mathrm{A} \leftarrow \mathrm{A} 2-\mathrm{Al}$

\section{CASO $\theta$}

$0 \leq \theta<90^{\circ}$ :

$\mathrm{SE} \triangle \mathrm{A}=\mathbf{0}$

ENTÃO Lista_Manobras $\leftarrow L M, T a b . A . l, l^{a}$ lin, ap. A

SENÃO SE $\triangle \mathrm{A}<0$

ENTÃo Estimar Vd e Td (pág. 92)

DNd $\leftarrow$ Calc_Dist_Nec_Desc $(\mathrm{Vd}, \mathrm{Td}, \triangle \mathrm{A})\{$ pag. 96\}

SE Di $\geq$ DNd

ENTĀO Lista_Manobras $\leftarrow L M, T a b . A .1,2^{a}$ lin, ap. A

SENÃO Lista_Manobras $\leftarrow L M, T a b . A .1,3^{a} \operatorname{lin}, a p$. A

SENÃO Estimar Vy e Mts (pág. 92)

DNa $\leftarrow$ Calc_Dist_Nec_ascend $(V y, M t s, \triangle A)$ (pag. 96)

SE Di $\geq$ DNa

ENTÃO Lista_Manobras $\leftarrow L M, T a b . A .1,4^{a}$ lin, ap. $A$

SENÃO Lista_Manobras $\leftarrow L M$, Tab. A.l, $5^{a} \mathrm{lin}$, ap. A

$90 \leq \theta<180^{\circ}$ :

Ler raio, r, da tabela Parâmetros

DNc $\leftarrow$ Calc_Dist_Nec_curva $(\theta, r)$ (pág. 101)

SE $\triangle A=0$

ENTÃO SE Di $\geq$ DNc

ENTÃo Calc_Ângulos_Curva (r, $\theta$, DNc, w1) (pag. 103)

Lista_Manobras $\leftarrow L M, T a b . A .2, l^{a}$ lin, ap. $A$

SENÃO Lista_Manobras $\leftarrow L M, T a b . A .2,2^{a}$ lin, ap. $A$

SENÃO SE $\triangle \mathrm{A}<0$

ENTÃO Estimar Vde Td \{pág. 92\}

DNd $\leftarrow$ Calc_Dist_Nec_Desc $(V d, T d, \triangle A)$ (pag. 96)

SE Di $\geq$ DNC + DNd

ENTÃo Calc_Ângulos_Curva (r, $\theta, \mathrm{DNc}, w 1)$ (pag. 103) 
Lista_Manobras $\leftarrow L M, T a b . A .2,3^{a}$ lin, ap. A

SENÃO SE Di $\geq$ DNd

ENTÃO Lista_Manobras $\leftarrow L M, T a b . A .2,4^{a}$ lin, ap. A

SENÃO Lista_Manobras $\leftarrow L M, T a b . A .2,5^{a}$ lin, ap. A

SENÃO Estimar Vy e Mts (pág. 92)

DNa $\leftarrow$ Calc_Dist_Nec_ascend (Vy, Mts, $\triangle \mathrm{A})$ (pag. 96)

$\mathrm{SE} \mathrm{Di} \geq \mathrm{DNc}+\mathrm{DNa}$

ENTÃO Calc_Ângulos_Curva (r, O, DNc, w1) (pag. 103)

Lista_Manobras $\leftarrow L M, T a b . A .2, \sigma^{a}$ lin, ap. A

SENÃO SE Di $\geq \mathrm{DNa}$

ENTÃO Lista_Manobras $\leftarrow L M, T a b . A .2, T^{a}$ lin, ap. A

SENÃO Lista_Manobras $\leftarrow L M, T a b . A .2,8^{a}$ lin, ap. A

$\theta=180^{\circ}$ :

SE $\triangle A=0$

ENTÃO Lista_Manobras $\leftarrow L M, T a b . A .3, I^{a}$ lin, ap. A

SENÃO SE $\triangle A<0$

ENTÃO Estimar Vd e Td (pág. 92)

DNd $\leftarrow$ Calc_Dist_Nec_Desc (Vd, Td, $\triangle A)$ (pag. 96)

SE Di $\geq$ DNd

ENTÃO Lista_Manobras $\leftarrow L M, T a b . A .3,2^{a}$ lin, ap. A

SENÃO Lista_Manobras $\leftarrow L M, T a b . A .3,3^{a}$ lin, ap. $A$

SENÃO Estimar Vy e Mis (pág. 92)

$\mathrm{DNa} \leftarrow$ Calc_Dist_Nec_ascend $(\mathrm{Vy}, \mathrm{Mts}, \triangle \mathrm{A})($ pag. 96)

SE Di $\geq \mathrm{DNa}$

ENTÃO Lista_Manobras $\leftarrow L M, T a b . A .3,4^{a}$ lin, ap. $A$

SENÃO Lista_Manobras $\leftarrow L M, T a b . A .3,5^{a}$ lin, ap. A

(para $\theta$ nos intervalos $180^{\circ}<\theta \leq 270^{\circ}$ e $270<\theta \leq 360^{\circ}$ o procedimento é análogo ao procedimento para $\theta$ nos intervalos $90 \leq \theta<180^{\circ}$ e $0 \leq \theta<90^{\circ}$, respectivamente, mudando apenas nas direçōes das curvas e no ângulo da última curva)

Retornar Lista_Manobras;

FIM 
(Verifica se o piloto automático, PA, está executando a manobra enviada corretamente)

MONITORAR_ROTA

INf́CIO

REPITA

ler posição e heading atuais da aeronave da tabela de sensores

CASO manobra

Vôo nivelado:

SE posição atual ESTÁ DENTRO da posição calculada+/-erro

ENTÃO SE posição atual+/-precisão = posição final

ENTÃO manobra finalizada

SENÃO

desvio de curso

calcular posição atual e ângulo de correção $\beta$ (Pág. 108)

SE $\beta \diamond 0$

ENTÃO enviar $\beta$ para o PA

Vô ascendente:

SE posiçāo atual ESTÁ DENTRO da posiçāo calculada+/-erro

ENTÃO SE posição atual+/-precisāo $=$ posição final

ENTÃO manobra finalizada

SENÃO

desvio de curso

calcular posição atual e ângulo de correção $\beta$ (Pág. 108)

SE $\beta \diamond 0$

ENTÃo enviar $\beta$ para o PA

Vôo descendente:

SE posição atual ESTÁ DENTRO da posição calculada+/-erro

ENTÃO SE posição atual+/-precisão = posição final ENTÃO manobra finalizada

SENÃO

desvio de curso

calcular posição atual e ângulo de correção $\beta$ (Pág. 108)

$\mathrm{SE} \beta \diamond 0$

ENTÃo enviar $\beta$ para o PA

Vôo em curva nivelada:

SE posiçāo atual ESTÁ DENTRO da posição calculada+/-erro

ENTÃo SE posição atual+/-precisão = posição final

ENTÃO manobra finalizada 
SENÃO desvio de curso

\section{FIM Caso}

Aguardar_Time_Out

ATE QUE manobra finalizada OU desvio de curso

RETORNAR desvio de curso ou manobra finalizada

FIM

[Coleta dados dos sensores na rede $I^{2} \mathrm{C}$ e os atualiza na tabela de sensores]

\section{COLETAR_DADO_SENSORX}

\section{INícIO}

ENQUANTO missão não finalizada e rede operacional e sensor em funcionamento

Ler dados da rede $\mathrm{I}^{2} \mathrm{C}$

SE valor lido

ENTÃO SE valor dentro da faixa de valores

ENTÃO atualizar tabela de sensores

SENÃO enviar mensagem de erro "Sensor defeituoso"

SENÃO enviar mensagem de erro "Rede não operacional"

\section{FIM ENQUANTO}

FIM 
[Ativa equipamento pertinente a cada tarefa e grava log de vôo]

CONTROLAR_EXECUÇĀo_TAREFAS

SE precisão do waypoint destino alcançada

\section{ENTÃo}

Ler tarefas associadas ao waypoint de destino;

SE tarefa = tirar fotografia

ENTÃo

ENQUANTO não fim número de fotografias associado à tarefa

Ativar câmera fotográfica

FIM ENQUANTO

Gravar Log de Vôo

SENÃO SE tarefa $=$ Filmar

ENTÃO Ativar filmadora durante tempo associado à tarefa

Gravar Log de Vôo

SENÃO SE tarefa = Finalizar Missão

ENTÃO enviar mensagem de Finalizar Missão para o PA

Gravar Log de Vôo

SENĀO Gravar log de Vôo sobre a tarefa abortada 